Cornell Law Library

Scholarship@Cornell Law: A Digital Repository

Cornell Law Faculty Publications

Faculty Scholarship

$11-2013$

\title{
The Merchants of Wall Street: Banking, Commerce, and Commodities
}

Saule T. Omarova

CornellLawSchool, sto24@cornell.edu

Follow this and additional works at: http://scholarship.law.cornell.edu/facpub

Part of the Banking and Finance Commons, and the Commercial Law Commons

\section{Recommended Citation}

Omarova, Saule T., "The Merchants of Wall Street: Banking, Commerce, and Commodities" (2013). Cornell Law Faculty Publications. Paper 1013.

http://scholarship.law.cornell.edu/facpub/1013

This Article is brought to you for free and open access by the Faculty Scholarship at Scholarship@Cornell Law: A Digital Repository. It has been accepted for inclusion in Cornell Law Faculty Publications by an authorized administrator of Scholarship@Cornell Law: A Digital Repository. For more information, please contact jmp8@cornell.edu. 


\title{
Article
}

\section{The Merchants of Wall Street: Banking, Commerce, and Commodities}

\author{
Saule T. Omarova ${ }^{\dagger}$
}

Introduction

I. What We Say: The Separation of Banking and

Commerce

A. Policy Reasons for Separating Banking from

General Commerce

B. The Gramm-Leach-Bliley Effect: Partial Mixing of Banking and Commerce

1. Financing Commerce: Merchant Banking

Powers

2. Pure Commerce: "Complementary" Powers ..... 285

3. A Special Kind of Commerce: Grandfathered Commodities Activities

II. What We See: Banking Organizations' Entry into

Physical Commodities and Energy Trading

A. Why Our Vision Is Obscured: A Note on the

Informational Gap

B. Let's Get Physical: The Scope of FHCs'

"Complementary" Powers

1. Permissible Physical Commodities Trading ..... 301

2. Energy Management and Energy Tolling

C. The Boundaries of "Complementarity" 307

$\dagger$ George R. Ward Associate Professor at the University of North Carolina at Chapel Hill School of Law. I would like to thank the organizers of and participants in the 2013 Harvard/Stanford/Yale Junior Faculty Forum, the "New Voices on Financial Market Regulation" conference at Cornell University Law School, a scholars' roundtable at Brooklyn Law School, and faculty workshops at Georgetown University Law Center, Washington and Lee University School of Law, and The George Washington University Law School. Special thanks to Robert Hockett, Tom Hazen, Adam Levitin, Lynn Stout, Heidi Schooner, Arthur Wilmarth, and Christopher Brummer for their comments and encouragement, and to Anne-Marie Tosco, Jacob Gerber, and Andrew Rohrkemper for their research assistance. All errors are mine. Copyright (C) 2013 by Saule T. Omarova. 
III. What We Don't (Yet) See: How the Crisis Changed the Physical Commodities Trading Game

A. Morgan Stanley and Goldman Sachs: Playing for the New Club

1. Morgan Stanley: Oil, Tankers, and Pipelines ... 313

2. Goldman Sachs: Metals, Warehouses, and Other Things

B. The Rise of JPMC: How Not to Waste a Crisis ...... 324

IV. What Say We? Legal, Policy, and Theoretical

Implications

A. Post-Crisis Legal Paradoxes: New Game Under Old Rules, or Old Game Under New Rules?

1. The BHCA Solution: Definitely, Maybe 334

2. The Discreet Charm of the Dodd-Frank Act .... 338

B. Rethinking the Foundational Myth: Should

Policy Permit Banks to Be Commodity

Merchants?

1. Safety and Soundness; Systemic Risk

2. Conflicts of Interest, Market Manipulation, and Consumer Protection

3. Concentration of Economic and Political

Power

4. Beyond the Foundational Myth: Limits of Governability and Regulatory Capacity

C. Beyond Banking: Pushing Conceptual and Theoretical Boundaries

"We move oil all over the world. We have barrels in storage. They are real, not just things on paper. They go on ships and they go to refineries."

\section{INTRODUCTION}

In June 2011, Coca-Cola ran out of patience . . . and aluminum. So the company filed a complaint with the London Metal Exchange (LME), the world's largest organized market for industrial metals, claiming that, for months, a wholly-owned subsidiary of Goldman Sachs Group, Inc. (Goldman) had hoarded enough commercial aluminum in its metal warehouses in De-

1. David Sheppard \& Alexandra Alper, As Banks Deepen Commodity Deals, Volcker Test Likely, REUTERS, July 3, 2012, available at http://www .reuters.com/article/2012/07/03/us-commodities-forwards-banks-idUSBRE8620 6420120703 (quoting an anonymous Wall Street bank executive). 
troit to drive global aluminum prices to record levels. ${ }^{2}$ For Coca-Cola, which uses aluminum cans to package its iconic soft drinks, this artificial delivery bottleneck at Goldman's metal warehouses meant an unjustified rise in operational costs and potential disruptions of its production process. ${ }^{3}$

On September 20, 2012, the Federal Energy Regulatory Commission (FERC) issued an order threatening to penalize JPMorgan Ventures Energy Corp., a wholly-owned subsidiary of JPMorgan Chase \& Co. (JPMC), for potentially misleading the agency in its probe of the company's allegedly manipulative trade practices. ${ }^{4}$ The FERC began its formal investigation in August 2011, after receiving complaints from electric power grid operators in California and the Midwest alleging that JPMC's power traders had intentionally inflated wholesale prices at which the company supplied these important regional markets with electricity. ${ }^{5}$

In July 2012, the Financial Times reported that JPMC, Goldman, and Morgan Stanley had struck similarly-structured deals, under which they would supply crude oil to several major U.S. oil refineries and buy those refineries' output for resale in the open market. ${ }^{6}$ Under the terms of these deals, financiallystrapped refineries would not have to worry about any of the logistical details of buying, storing, and transporting oil supplies or shipping their jet fuel and gasoline to customers-the experts at JPMC, Goldman and Morgan Stanley would take care of all of these operational details. ${ }^{7}$

On the surface, there is nothing particularly surprising about these seemingly unrelated snippets of recent news stories. Yet, when read together, they reveal something quite ex-

2. Dustin Walsh, Aluminum Bottleneck: Coke's Complaint: $12 \%$ of Global Stockpile Held Here, Boosting Prices, CRAIN'S DETROIT BUS. (June 26, 2011), http://www.crainsdetroit.com/article/20110626/FREE/306269994/aluminum -bottleneck-cokes-complaint-12-of-global-stockpile-held-here.

3. See id.

4. Kasia Klimasinska, JPMorgan Power-Trading Business Faces Suspension, FERC Says, BLOOMBERG (Sept. 20, 2012, 3:39 PM), http://www .bloomberg.com/news/2012-09-20/jpmorgan-power-trading-business-faces -suspension-ferc-says.html.

5. Gregory Meyer, JPMorgan in US Power Market Probe, FIN. TIMES, July 3, 2012, http://www.ft.com/intl/cms/s/0/0b9acbe4-c4fc-11e1-b6fd-00144fea bdc0.html?siteedition=intl\#axzz2eJtL04gA.

6. Gregory Meyer, Wall Street Banks Step up Oil Trade Role, FIN. TIMES, July 15, 2012, http://www.ft.com/intl/cms/s/0/96c4dd5e-ce70-11e1-9fa7-00144fe abdc0.html\#axzz2d1EU7Cie.

7. Id. 
traordinary and puzzling about current trends in the U.S. banking sector-and the current state of U.S. bank regulation.

The root of the puzzlement is the fact that all three of these institutions-Goldman, JPMC, and Morgan Stanley-are registered U.S. bank holding companies (BHCs) that own or control at least one U.S. commercial bank and, by virtue of that fact, are subject to extensive regulation and supervision by the Board of Governors of the Federal Reserve System (the Board). ${ }^{8}$ One of the core principles underlying and shaping the elaborate regulatory regime applicable to all U.S. banks and BHCs is the principle of separation of banking and commerce. ${ }^{9}$ Pursuant to that principle, U.S. commercial banks generally are not permitted to conduct any activities that do not fall within the relatively narrow band of the statutory concept of "the business of banking." ${ }^{10}$ Moreover, under the Bank Holding Company Act of 1956 (BHCA), ${ }^{11}$ BHCs-companies that own or control U.S. banks-are generally restricted in their ability to engage in any business activities other than banking or managing banks, although they may conduct a wider variety of financial activities through their non-depository subsidiaries. ${ }^{12}$ Certain BHCs qualifying for the status of "financial holding company" (FHC) may conduct broader activities that are "financial in nature," including securities dealing and insurance underwriting. ${ }^{13}$

This foundational structural feature of U.S. bank regulation sets it apart from the regimes found in much of the rest of the world's economies, where so-called "universal banking" remains the prevailing model. ${ }^{14}$ Yet, in the last decade, large U.S. FHCs-including Goldman, Morgan Stanley, and JPMCemerged as major merchants of physical commodities and energy, notwithstanding the legal wall designed to keep them out

8. Robert Schroeder, Goldman, Morgan to Become Holding Companies, MARKETWATCH (Sept. 21, 2008, 11:50 PM), http://www.marketwatch.com/ story/goldman-sachs-morgan-stanley-to-become-bank-holding-companies.

9. See Bernard Shull, Banking and Commerce in the United States, $18 \mathrm{~J}$. BANKING \& FIN. 255, 267 (1994); Bernard Shull, The Separation of Banking and Commerce in the United States: An Examination of the Principal Issues, 8 FIN. MARKETS, INSTITUTIONS \& INSTRUMENTS 1, 1 (1999) [hereinafter Separation].

10. 12 U.S.C. $\S 24$ (2012).

11. Bank Holding Company Act of 1956 , Pub. L. No. $84-511, \S 4,70$ Stat. $133,135-37$ (1956) (codified as amended at 12 U.S.C. $\$ \$ 1841-1848(2012)$ ).

12. 12 U.S.C. $\S \S 1841-1843$ (2012).

13. Id. $\S 1843(\mathrm{k})(1)(\mathrm{A})$.

14. Separation, supra note 9, at 14-15. 
of any non-financial business. ${ }^{15}$ The implications are more than merely doctrinal. While policy-makers are struggling with the perplexing question of how to reduce the risks posed by the $\mathrm{fi}$ nancial activities of "too-big-to-fail" banking institutions, the latter are growing even bigger-and potentially riskier and less manageable-by expanding their operations far beyond finance.

This Article advances two principal sets of claims. First, as a matter of doctrinal integrity, it argues that the quiet transformation of U.S. FHCs into global merchants of physical commodities effectively nullifies the foundational principle of separation of banking from commerce. The Article puts together the first comprehensive account to date of what is publicly known about the nature and scope of U.S. banking organizations' physical commodities activities and examines the existing legal and regulatory framework for conducting such activities. It argues that the BHCA does not provide a sufficiently robust structure for the regulation and supervision of FHCs' extensive commercial operations in global commodity and energy markets. Statutory authorizations of FHCs' merchant banking operations, activities "complementary" to a financial activity, and grandfathered commodities businesses fail to establish meaningful limitations on the expansion of their physical commodities operations in practice. ${ }^{16}$

Second, as a normative matter, the Article argues that FHCs' physical commodities activities raise potentially serious public policy concerns that may be divided into two closely related categories. To begin with, these activities threaten to undermine the fundamental policy objectives that underlie the principle of separating banking from commerce: ensuring the safety and soundness of the U.S. banking system, maintaining a fair and efficient flow of credit in the economy, protecting market integrity, and preventing excessive concentration of economic power. As the Article shows, all of these traditional concerns assume a new, heightened significance in the context of banks' involvement in the trading of physical commodities and energy. ${ }^{17}$ The need to prevent potentially excessive accumulations of both risk exposure and market power in the hands of a few large FHCs is paramount in this respect. When the same banking organizations that control access to money and credit also control access to such universal production inputs as

15. See supra notes $2-5$.

16. See infra Part I.B.

17. See infra Part IV.B. 
raw materials and energy, they are in a position to exercise disproportionate control over the entire economic-and, by extension, political-system. In this context, it is important to remind ourselves of Justice Brandeis's famous warnings against the threat to American democracy posed by financial institutions accumulating direct control over the country's industrial enterprises. ${ }^{18}$ Brandeis's words ring as alarmingly true today as they did nearly a hundred years ago. If there are good reasons to believe that extreme power breeds extreme abuses, the ongoing expansion of large FHCs into physical commodities and energy business warrants serious concern.

Beyond the traditional normative justifications for separating banking from commerce, the Article argues that FHCs' expansion into physical commodities implicates a distinct set of policy concerns relating to potential new sources and transmission channels of systemic risk, the integrity and efficacy of the regulatory process, and the governability of financial markets and institutions. Understanding FHCs' roles as energy and commodity merchants challenges our current notions of how systemic risk originates and spreads throughout the economy and puts into a broader substantive context the search for more effective mechanisms of systemic risk containment. ${ }^{19}$ When financial institutions act as traders and dealers in physical commodities, they assume a variety of new financial and nonfinancial risks-including operational, environmental, and geopolitical risks-that fundamentally alter their business and risk profiles. In addition to risks inherent in their traditional business of providing financial services, these institutions become directly dependent on the operation of the multitude of factors shaping the costs of doing business in each individual commodity market. ${ }^{20}$ Given the high degree of interconnected-

18. LOUTS D. BRANDEIS, OTHER PEOPLE'S MONEY: AND HOW THE BANKERS USE IT 3-5 (1933).

19. Systemic risk can be defined as:

the risk that (i) an economic shock such as market or institutional failure triggers (through a panic or otherwise) either (X) the failure of a chain of markets or institutions or $(\mathrm{Y})$ a chain of significant losses to financial institutions, (ii) resulting in increases in the cost of capital or decreases in its availability, often evidenced by substantial financial-market price volatility.

Steven L. Schwarcz, Systemic Risk, 97 GEo. L.J. 193, 204 (2008).

20. See Commodities-Oil, Gold Slide but Post Big Monthly Gains, REUTERS, Aug. 30, 2013, available at http://www.reuters.com/article/2013/08/ 30/markets-commodities-idUSL2N0GV10520130830 (discussing different commodities' price shifts). Markets for different commodities-oil, natural gas, 
ness among financial institutions, this new source of vulnerability creates new, more complex patterns of systemic fragility and risk contagion. ${ }^{21}$ It also makes these emerging financialindustrial conglomerates nearly impossible to manage, regulate, and supervise in accordance with the micro- and macroprudential policy objectives of post-crisis financial services regulation.

By identifying and analyzing these issues, the Article aims to contribute to both the long-standing academic debate on the efficacy and desirability of separating banking from commerce, on the one hand, and to the growing scholarly literature on the nature and regulation of systemic risk in financial markets, on the other. The policy implications of the analysis, moreover, reach beyond the realm of U.S. banking law and its foundational principles. Many of the same public policy concerns that arise with respect to banking organizations' commodity trading-heightened potential for conflicts of interest and market manipulation, an excessive concentration of market power, increased systemic risk from direct linkages between financial markets and economically vital commodities markets, and lessened governability of financial institutions-are also implicated when non-bank systemically important financial institutions (SIFIs) engage in such activities. This in turn raises broader theoretical questions concerning the very nature and social function of modern financial intermediation. Is it in the public interest to allow financial intermediaries in general-and SIFIs in particular-to engage in commercial business activities related to physical commodities and energy trading, a critically important sphere of economic activity? Or does the mixing of finance-as opposed to just banking-with this particular form of commerce create unique risks from the perspective of systemic stability and the integrity and efficiency of today's interconnected markets? While a full consideration of these issues is beyond the scope of the present Article, a factually-grounded

coal, electricity, and various precious and base metals-display different characteristics in terms of market structure and dynamics, the relative salience of various economic and political factors in determining prices and costs of doing business, and the applicable regulatory scheme. See id. (discussing different commodities' price shifts). The nature of the commodity-its physical characteristics, economic uses, and geographic concentration-accounts for many of these differences. Id. This diversity of commodity markets further complicates the task of effective systemic oversight of FHCs' role in them.

21. Id. 
examination of U.S. banking organizations' role in commodity markets lays a conceptual foundation for future deliberation.

There is a particular urgency to focusing upon that role now, as Goldman and Morgan Stanley, which converted to BHC status at the height of the financial crisis in September 2008, ${ }^{22}$ are at the end of the five-year grace period during which they had to either divest their impermissible commercial businesses or find legal authority under the BHCA for keeping them. ${ }^{23}$ In the fall of 2013, the Board has to determine whether these firms may continue their existing commodities operations and, if so, under what conditions. ${ }^{24}$ Both firms have been reportedly lobbying the Board to allow them to keep their existing physical commodities assets and operations. ${ }^{25}$ Given its potential significance, this issue should not be left to behind-the-scene negotiations between the banks and their regulators. By drawing attention to this problem, this Article aims to reclaim the public's right to participate in important public policy decisions.

Reaching beyond the impending Board ruling, however, the Article calls for a thorough reconsideration of the entire legal and regulatory framework for large financial institutions' activities in physical commodity markets. Whether Goldman and Morgan Stanley expand or contract their existing commodity investments is only one aspect of the broader and far more critical inquiry into the proper legal boundaries for financial intermediaries' direct involvement in commodities trade and production. Even if individual firms were to scale down their physical commodities operations in the near future, either in response to post-crisis market trends or as a result of regulatory action, it would not obviate the need to reassess the fundamental norms and principles underlying the current system of financial services regulation.

Despite both its immediate urgency and its broader doctrinal, policy, and conceptual significance, this topic has been largely ignored to date. ${ }^{26}$ In part, this lack of scholarly attention

22. Schroeder, supra note 8 .

23. See infra Part III.

24. See infra Part III.

25. See David Sheppard et al., Wall Street, Fed Face Off Over Commodities, REUTERS, Mar. 2, 2012, available at http://www.reuters.com/article/2012/ 03/02/us-fed-banks-commodities-idUSTRE8211CC20120302.

26. In recent years, the academic and policy discussions of the doctrine of separation of banking from commerce focused mainly on issues posed by the attempts of commercial companies-most notably, Wal-Mart Stores Inc.- to develop banking capabilities. See Mehrsa Baradaran, Reconsidering the Sepa- 
and analysis may be explained by what appears to be the deliberately obscure nature of banking organizations' commodity operations and lack-or extreme inadequacy-of publicly available information on the structure and scope of such operations. It is virtually impossible to glean even a broad overall picture of Goldman's, Morgan Stanley's, or JPMC's physical commodities activities from their public filings with the Securities and Exchange Commission (SEC) and federal bank regulators. Although this Article cannot fill that informational gap, it takes the first step toward that goal by analyzing and synthesizing publicly available information on the subject and identifying the key areas in which further inquiry and deliberation are called for.

The Article is structured as follows. Part I describes the normative basis for the separation of banking and commerce in the U.S. and outlines the key legal and regulatory conditions under which FHCs may conduct commercial activities. Part II analyzes the process and consequences of regulatory expansion, between 2000 and 2008, of FHCs' authority to engage in physical commodity trading as an activity "complementary" to financial activities. Part III examines key changes in the nature and scope of physical commodities activities on the part of U.S. banking organizations in the wake of the recent financial crisis. Part IV discusses legal, normative, and theoretical implications of these phenomena for the ongoing process of financial regulation reform.

\section{WHAT WE SAY: THE SEPARATION OF BANKING AND COMMERCE}

The separation of banking and commerce is one of the fundamental principles underlying the U.S. system of bank regulation. ${ }^{27}$ State and federal banking statutes impose a complex web of restrictions and prohibitions on the business activities and investments of U.S. commercial banks and their affiliates. ${ }^{28}$ This Part describes the doctrine and its policy rationales

ration of Banking and Commerce, 80 GEO. WASH. L. REV. 385, 385 (2012) (arguing that if companies like Wal-Mart owned banks, the financial structure would be more diverse and less risk-prone); Arthur E. Wilmarth, Jr., Wal-Mart and the Separation of Banking and Commerce, 39 CONN. L. REV. 1539, 1539 (2007) (discussing Wal-Mart's attempt to acquire FDIC-insured industrial loan companies).

27. See supra note 9 and accompanying text.

28. See Saule T. Omarova \& Margaret E. Tahyar, That Which We Call a Bank: Revisiting the History of Bank Holding Company Regulation in the 
and analyzes the three principal sources of FHCs' legal authority to conduct purely commercial activities.

\section{A. POLICY REASONS FOR SEPARATING BANKING FROM GENERAL COMMERCE}

Historically, banks in the United States have been granted charters with only limited powers. The National Bank Act of 1863 grants federally-chartered, or national, banks:

all such incidental powers as shall be necessary to carry on the business of banking; by discounting and negotiating promissory notes, drafts, bills of exchange, and other evidences of debt; by receiving deposits; by buying and selling exchange, coin, and bullion; by loaning money on personal security; and by obtaining, issuing, and circulating notes. $^{29}$

In the last three decades, the Office of the Comptroller of the Currency (OCC), the principal regulator of national banks, has consistently interpreted the statutory language in a manner that has significantly expanded the outer boundaries of the "business of banking." ${ }^{30}$ Nevertheless, commercial banks remain subject to restrictive ${ }^{31}$ balance sheet regulation and are generally prohibited from engaging in non-banking activities. ${ }^{32}$

In addition to the statutory grants of only limited powers to banks, the Glass-Steagall Act of 1933 prohibited banks from participating in the securities dealing and underwriting business and from affiliating with securities firms. ${ }^{33}$ The GlassSteagall Act, however, did not preclude banks from affiliating with firms engaged in purely commercial activities. Only since the enactment of the BHCA in 1956, have companies that own or control U.S. banks ${ }^{34}$-BHCs--been subject to a separate set of legal restrictions on their business activities. ${ }^{35}$ The BHCA is

United States, 31 REV. BANKING \& FIN. L. 113, 118-21 (2011).

29. 12 U.S.C. \& 24 (2012).

30. See Saule T. Omarova, The Quiet Metamorphosis: How Derivatives Changed the "Business of Banking," 63 U. MIAMI L. REV. 1041, 1077 (2009).

31. See Tom Braithwaite \& Patrick Jenkins, Finance: Balance Sheet Battle, Fin. TIMES, Aug. 14, 2013, http://www.ft.com/intl/cms/s/0/b42fd1f6-ff7e -11e2-a244-00144feab7de.html\#axzz2eJtL04gA.

32. Omarova, supra note 30 , at 1050.

33. Banking Act of 1933, Pub. L. No. 73-66, 48 Stat. 162, 184-85 (1933) (codified as amended in scattered sections of 12 U.S.C. (2012)).

34. 12 U.S.C. $§ 1841(a)(1)$ (2012). Although the definition of "control" for purposes of determining whether an entity is a BHC is complicated and factdependent, the statute generally presumes the existence of "control" where an entity owns more than twenty-five percent of any class of voting shares of a bank. Id. $\S 1841(\mathrm{a})(2)(\mathrm{A})$.

35. Id. $\S \S 1841-1843$. 
the federal statute that most explicitly operationalizes the principle of separation of banking and commerce. It does so by restricting the permissible activities and investments of BHCs to banking, managing or owning banks, and a limited set of activities determined to be "closely related to banking." ${ }^{\text {"36 }}$ BHCs are required to register with, and become subject to an extensive regime of consolidated regulation and supervision by, the Board. ${ }^{37}$ Thus, BHCs submit mandatory periodic reports to the Board, which has direct examination and enforcement authority over them. ${ }^{38}$ They are subject to capital adequacy regulation and must serve as a "source of strength" to their bank subsidiaries. ${ }^{39}$ Yet, it is the loss of legal authority to own a significant ownership stake in non-financial-and even many non-banking financial businesses-that is often viewed as the most severe consequence faced by any company that acquires a U.S. bank and thereby becomes a BHC. ${ }^{40}$

In effect, the entire system of U.S. bank and BHC regulation is designed to keep institutions that are engaged in deposit-taking and commercial lending activities from conducting, directly or through some business combination, any significant non-financial activities, or from holding significant interests in any general commercial enterprise. The main arguments in favor of maintaining this legal wall between the "business of banking" and purely commercial business activities have traditionally included the needs to preserve the safety and soundness of insured depository institutions, to ensure a fair and efficient flow of credit to productive economic enterprise, and to prevent excessive concentration of financial and economic power in the financial sector. ${ }^{41}$

The safety and soundness argument generally posits that exposing federally insured depository institutions to the risks associated with manufacturing and commercial activities increases the vulnerability of the banking and payments systems, the federal deposit insurance fund, and thereby the broader

36. Id. § 1843(c)(8).

37. Id. $\S 1844(\mathrm{a}),(\mathrm{b})$.

38. Id. \& 1844(c).

39. Adam Ashcraft, Are Bank Holding Companies a Source of Strength to Their Banking Subsidiaries?, 40 J. MONEY, CREDIT, \& BANKING 273, 273-74 (2008).

40. Schroeder, supra note 8 (suggesting Federal oversight is the biggest negative to becoming a $\mathrm{BHC}$ ).

41. Separation, supra note 9 , at $29-30,46-47,52$ (discussing policy arguments of maintaining a wall between banking and commerce). 
economy. To the extent that this argument relies on an assumption that all commercial activities are inherently more risky and volatile than purely financial activities, it may not be particularly convincing. There are also potential diversification benefits that may support allowing banks to invest, at least to some extent, in commercial enterprises. At the same time, however, some commercial activities may pose greater risks or require more specialized and expensive risk management and monitoring than others. Allowing banks to conduct such activities may therefore increase the exposure of the federal deposit insurance system to the ups and downs of unrelated commercial markets.

The need to ensure an impartial and efficient allocation of credit throughout the national economy provides another compelling justification for disallowing the mixing of banking and commerce. Traditionally, one of the key policy concerns in this area has been the prevention of potential conflicts of interest. Affiliation with commercial companies may create powerful incentives for banks to make important lending decisions on the basis of such decisions' potential impact on their commercial affiliates' financial condition or profitability. Price discrimination, unfair restriction of access to credit, and other anti-competitive banking practices may not only hurt the individual commercial companies not affiliated with banks, but also significantly undermine a nation's economic productivity and growth. To date, empirical research has not produced definitive evidence either to support or to defeat this argument. As a plausible prudential policy concern, however, it remains an important factor.

Perhaps the most compelling policy reason for institutionalizing the separation of banking from commerce, especially through regulatory restrictions on BHCs' activities, is the prevention of excessive concentration of economic-and ultimately political-power in the hands of large financial-industrial conglomerates. In fact, the BHCA was originally designed principally as an antitrust, anti-monopoly law. ${ }^{42}$ According to the author of the leading treatise on the subject:

Bank holding company regulation in the United States historically has had two overriding goals: to prevent the unrestrained concentration of banking resources under the control of a single organization, and to prevent undue concentration of economic power that Congress perceived may result when banking and nonbanking enterprises com-

42. Note, The Bank Holding Company Act of 1956, 9 STAN. L. REv. 333, 346 (1957). 
bine under the same corporate umbrella. ${ }^{43}$

This explicitly anti-monopoly policy focus of the BHCA has its roots in the long-standing American tradition of mistrust of "big business" and "high finance," along with a corresponding preference for small, local business enterprise as a unit of economic activity. ${ }^{44}$ The very enactment of the BHCA was in significant measure the product of successful political lobbying by small independent and community banks, trying to protect their local markets from potential competition from large outof-state banks. ${ }^{45}$ In recent decades, however, the political economy of the U.S. financial services sector has changed dramatically, as a small number of large, internationally active financial conglomerates have become dominant economic and political actors in the industry. ${ }^{46}$ As part of this process, the original antitrust thrust of U.S. bank holding company regulation has faded in significance and come to be largely forgotten. ${ }^{47}$ Yet, in the wake of the recent financial crisis, which exposed the potential systemic dangers of allowing unchecked growth of "too-big-to-fail" conglomerates, there is a strong argument for reviving and strengthening the policy of preventing excessive concentration of economic and political power in the financial services sector. From this perspective, it becomes particularly important to revisit the basis for, and the role of, the principle of separation of banking and commerce.

It should be noted, however, that in practice the relationship between banking and commerce in the United States has long followed a non-linear and complex pattern, as the legal wall separating them has never been completely impenetrable. ${ }^{48}$ Numerous exemptions from the general statutory restrictions on affiliations, such as the exemption for unitary thrift holding companies ${ }^{49}$ or companies controlling certain

43. Melanie Fein, Federal BanK Holding Company LaW $§ 7.02[1]$, at 7-4 (3d ed. 2013).

44. See Mark Roe, Strong Managers, Weak OWners: The Political ROOTS OF AMERICAN CORPORATE FINANCE 98-99 (1994).

45. For a discussion of the origins and history of the BHCA, see generally Omarova \& Tahyar, supra note 28 , at 113.

46. Id. at 124.

47. Id. at $123-24$.

48. See Joseph G. Haubrich \& João A. C. Santos, Alternative Forms of Mixing Banking with Commerce: Evidence from American History, 12 FIN. MARKETS, INSTITUTIONS \& INSTRUMENTS 121, 122 (2003) (arguing that "banking and commerce in the United States has a convoluted and obscure history").

49. 12 U.S.C. $\$ 1467 \mathrm{a}(\mathrm{c})(3)(2012)$. 
state-chartered industrial banks, ${ }^{50}$ historically have allowed a wide variety of commercial firms to own and operate deposittaking institutions. ${ }^{51}$ Banks and BHCs, in turn, have always been allowed at least some degree of involvement in nonfinancial activities, even if subject to various statutory and regulatory conditions and limitations. Not surprisingly, against that backdrop, the efficacy and desirability of the separation of banking and commerce as the principal method of achieving its stated policy goals - protecting the safety and soundness of the depository system, ensuring an impartial and efficient allocation of credit, and preventing an excessive concentration of economic power-continue to be subjects of intense debates. ${ }^{52}$

\section{B. The GRAMM-LEACH-Bliley EFFECT: PARTIAL MIXING OF BANKING AND COMMERCE}

In recent decades, fundamental changes in the nature and scope of financial intermediation have made the continuing relevance of the separation of banking and commerce particularly salient. Beginning in the late 1970s, U.S. banks came under increasing pressure to move away from the traditional spreaddriven banking business model, in response to the so-called process of "disintermediation. ${ }^{53}$ As more lightly regulated investment banks began offering new products and services that competed with traditional banking products, banks sought to regain their profitability by expanding into capital markets. ${ }^{54}$ Technologically driven processes of financial innovation and globalization enabled financial institutions to continuously ex-

50. $I d . \S 1841(\mathrm{c})(2)(\mathrm{H})$

51. General Electric is perhaps the best-known example of a unitary thrift holding company that combines industrial operations with a successful financial business run through its subsidiary, GE Capital. See Paul Glader, Is GE Capital Another CIT Waiting to Happen?, WALL ST. J. DEAL J. BLOG (July 17, 2009, 10:15 AM), http://blogs.wsj.com/deals/2009/07/17/tale-of-the-tape-cit-v -general-electric.

52. See, e.g., Jonathan R. Macey \& Geoffrey P. Miller, Corporate Governance and Commercial Banking: A Comparative Examination of Germany, Japan, and the United States, 48 STAN. L. REV. 73, 73-75 (1995); John R. Walter, Banking and Commerce: Tear Down This Wall?, ECON. Q., Spring 2003, http:// www.richmondfed.org/publications/research/economic_quarterly/2003/spring/ walter.cfm.

53. Omarova \& Tahyar, supra note 28 , at 125.

54. See Valentine V. Craig, Merchant Banking: Past and Present, FDIC BANKING REV. 29, 32-33 (2002) (discussing the evolution of banks' capital investments). 
pand their activities and sources of revenues. ${ }^{55}$

In this context, the Glass-Steagall Act, which prohibited BHCs from conducting lucrative securities trading and dealing activities, became the primary target of the banking industry's deregulatory campaign. ${ }^{56}$ Throughout the $1980 \mathrm{~s}$ and $1990 \mathrm{~s}$, the industry's lobbying efforts led to significant piecemeal erosion of the Glass-Steagall regime by regulatory action. ${ }^{57}$ During that period, the Board consistently relaxed statutory activity limitations on BHCs, most notably by interpreting the Glass-Steagall Act to permit so-called "Section 20" subsidiaries of BHCs to underwrite securities, as long as these activities generated no more than five percent of such subsidiaries' revenues. ${ }^{58}$ By 1996, the Board increased the revenue ceiling to twenty-five percent, thus allowing many BHCs to acquire regional investment banking firms.

At the same time, the OCC engaged in parallel efforts to relax statutory restrictions on commercial banks' activities, by ever more broadly interpreting the statutory term "business of banking." ${ }^{60}$ Perhaps most importantly, the OCC's interpretations allowed U.S. banks to engage in an increasingly broad range of new derivatives activities, including trading and dealing in derivatives instruments linked to various commodities. ${ }^{61}$

Finally, Congress partially repealed the Glass-Steagall Act in enacting the Gramm-Leach-Bliley Act of 1999 (the GLBA). ${ }^{62}$ The GLBA amended the BHCA to allow commercial banks and securities firms to affiliate under a newly-created FHC structure. ${ }^{63}$ Specifically, the main operative provision of section $4(\mathrm{k})$ of the BHCA, added by the GLBA, states that an FHC:

55. Charles W. Murdock, The Big Banks: Background, Deregulation, Financial Innovation, and "Too Big to Fail," 90 DENV. U. L. REV. 505, 529-30 (2012).

56. Id. at 518-19 (discussing the demise of the Glass-Steagall Act).

57. Id.

58. See FEIN, supra note $43, \S 18-06[4]$, at 18-27 to 18-29.

59. See LisSa L. Broome \& JeRry W. MARKHAM, REgulation of BaNK FINANCIAL SERVICE ACTIVITIES 764 (4th ed. 2011).

60. See Omarova, supra note 30 , at 1077.

61. Id.

62. Financial Services Modernization (Gramm-Leach-Bliley) Act, Pub. L. No. 106-102, 113 Stat. 1338, 1341 (1999) (codified as amended at 15 U.S.C. $\S \S 6801-6809(2012))$.

63. 12 U.S.C. $\S 1843(\mathrm{k})(1)$ (2012). To become an FHC, a BHC has to meet a list of statutory criteria, the most important of which requires that the BHC itself and all of its deposit-taking subsidiaries are well-capitalized and wellmanaged. Id. 
may engage in any activity, and may acquire and retain the shares of any company engaged in any activity, that the Board ... determines (by regulation or order) -

(A) to be financial in nature or incidental to such financial activity; or

(B) is complementary to a financial activity and does not pose a substantial risk to the safety or soundness of depository institutions or the financial system generally. ${ }^{64}$

The main goal of the new regime was to allow an expansion of financial activities of banking organizations through organizational affiliations. To make these business combinations viable as a practical matter, the statute also authorized FHCs to conduct certain non-financial activities impermissible for mere BHCs not qualifying for that new regulatory status. ${ }^{65}$ Generally, however, an FHC may acquire shares of any entity engaged, either exclusively or partly, in non-financial activities, only pursuant to a specific grant of statutory authority.

Three principal provisions of the GLBA enable FHCs to engage in commercial activities on a much broader scale than before. First, an FHC may make passive private equity investments of any size in any commercial company under the socalled "merchant banking" authority. ${ }^{66}$ Second, an FHC may directly engage in purely commercial activities determined to be "complementary" to a financial activity. ${ }^{67}$ Finally, Congress also provided a special grandfathering provision for commodity activities of certain entities that become subject to the BHCA after the GLBA enactment. ${ }^{68}$ Thus, while directly targeting the Glass-Steagall separation between commercial and investment banking, the GLBA also significantly undermined the broaderreaching wall separating banking from commerce.

64. Id.

65. Unlike commercial banks, U.S. securities firms were not subject to prohibitions or restrictions on their business activities and were generally free to engage in any commercial activity. If forced to divest all of their pre-GLBA non-financial investments and assets, investment banks were unlikely to agree to any business combination with a BHC.

66. 12 U.S.C. $\S 1843(\mathrm{k})(4)(\mathrm{H})(7)$.

67. Id. $\S 1843(\mathrm{k})(1)(\mathrm{B})$.

68. Id. $\$ 1843(0)$. The GLBA also added a separate section grandfathering a broader swath of non-financial activities of the entities that became subject to the BHCA (and elect the FHC status) after November 12, 1999. Id. $\S 1843(\mathrm{n})$. A special sunset provision, however, required an FHC to terminate any such grandfathered commercial activities no later than November 12 , 2009 , unless the Board extended the divestiture date for such an FHC for up to an additional five years (until November 12, 2014). Id. $\S 1843(\mathrm{n})(7)$. This statutory provision has little practical significance in the context of Goldman's and Morgan Stanley's current efforts to retain their commodity assets. 


\section{Financing Commerce: Merchant Banking Powers}

Prior to the enactment of the GLBA, a BHC was generally permitted to make passive private equity investments in any commercial company only if such investments did not exceed, in each case, five percent of such company's voting securities. ${ }^{69}$ The relatively low percentage ceiling on such permissible investments was designed primarily to ensure that BHCs did not acquire control of commercial entities and remained strictly passive investors in any such entities. ${ }^{70}$ The GLBA greatly expanded the ability of certain qualifying $\mathrm{BHCs}$-namely, those registering under the newly created category of FHCs-to make passive equity investments by granting FHCs so-called merchant banking powers. ${ }^{71}$

The merchant banking authority permits an FHC to acquire or control, directly or indirectly, up to $100 \%$ of any kind of ownership interest-including equity or debt securities, partnership interests, trust certificates, warrants, options, or any other instruments evidencing ownership-in any entity that engages in purely commercial, as opposed to financial, activities. $^{72}$ By creating this new investment authority, the GLBA enabled FHCs to conduct a broad range of securities underwriting, investment banking, and merchant banking activities, subject to statutory conditions and limitations. Most importantly, at the height of the high-tech stock boom, the GLBA's grant of merchant banking powers allowed FHCs to compete with securities firms and venture-capital funds by investing in technology start-ups. ${ }^{73}$

Historically rooted in the European tradition of trade finance, by the late 1990s, merchant banking denoted various forms of private equity investments, including leveraged buyouts and venture-capital funding of start-up companies. ${ }^{74}$ Interestingly, however, the statute does not define the term "merchant banking." In 2001, the Board and the Department of Treasury jointly issued a final rule implementing section $4(\mathrm{k})(4)(\mathrm{H})$ of the BHCA (the Merchant Banking Rule). ${ }^{75}$ The

69. Id. § 1843(c)(6)-(7).

70. 12 C.F.R. $\S 225.137$ (2013).

71. 12 U.S.C. $\$ 1843(\mathrm{k})(4)(\mathrm{H}),(7)$.

72. Id. $\S 1843(\mathrm{k})(4)(\mathrm{H})$.

73. Craig, supra note 54, at 33.

74. See id. at 29-30.

75. Bank Holding Companies and Change in Bank Control, 66 Fed. Reg. $8,466,8,484-85$ (Jan. 31,2001 ) (codified at 12 C.F.R. $\$ 225.170$ (2013)). 
Merchant Banking Rule defines "merchant banking" activities and investments as those activities and investments that are not otherwise authorized under section 4 of the BHCA. ${ }^{76}$ In effect, the merchant banking power serves as a catch-all authority for FHCs to invest in commercial enterprises, as long as any such investment meets the following five requirements ${ }^{77}$ :

(1) the investment is not made or held, directly or indirectly, by a U.S. depository institution (such as a bank subsidiary of the $\mathrm{FHC}){ }^{78}$

(2) the investment is made "as part of a bona fide underwriting or merchant or investment banking activity," which includes investments made "for the purpose of appreciation and ultimate resale"; ${ }^{79}$

(3) the FHC either (i) is or has a securities broker-dealer affiliate, or (ii) has both (A) an insurance company affiliate that is predominantly engaged in underwriting life, accident and health, or property and casualty insurance (other than creditrelated insurance), or providing and issuing annuities and (B) a registered investment adviser affiliate that provides investment advice to an insurance company; ${ }^{80}$

(4) the investment is held "only for a period of time to enable the sale or disposition thereof on a reasonable basis consistent with the financial viability of the FHC's merchant banking investment activities"; ${ }^{81}$ and

(5) the FHC does not "routinely manage or operate" any portfolio company in which it made the investment, except as

76. 12 C.F.R. $\S 225.170$ (a) (2013). The Merchant Banking Rule provides the following definition:

Section $4(\mathrm{k})(4)(\mathrm{H})$ of the Bank Holding Company Act (12 U.S.C. $\S 1843(\mathrm{k})(4)(\mathrm{H}))$ and this subpart authorize a financial holding company, directly or indirectly and as principal or on behalf of one or more persons, to acquire or control any amount of shares, assets or ownership interests of a company or other entity that is engaged in any activity not otherwise authorized for the financial holding company under section 4 of the Bank Holding Company Act. For purposes of this subpart, shares, assets or ownership interests acquired or controlled under section $4(\mathrm{k})(4)(\mathrm{H})$ and this subpart are referred to as Id.

"merchant banking investments."

77. Id.

78. 12 U.S.C. $\$ 1843(\mathrm{k})(4)(\mathrm{H})(\mathrm{i})(2012) ; 12$ C.F.R. $\$ 225.170(\mathrm{~d})$.

79. 12 U.S.C. $\S 1843(\mathrm{k})(4)(\mathrm{H})(\mathrm{ii}) ; 12$ C.F.R. $\S 225.170(\mathrm{~b})$.

80. 12 U.S.C. $\S 1843(\mathrm{k})(4)(\mathrm{H})(\mathrm{ii}) ; 12$ C.F.R. $\S 225.170(\mathrm{f})$. The merchant banking investment need not be held by or through the securities or insurance affiliates of the FHC. 12 U.S.C. $\S 1843(\mathrm{k})(4)(\mathrm{H})(\mathrm{ii}) ; 12$ C.F.R. $\S 225.170(\mathrm{f})$.

81. 12 U.S.C. $\S 1843(\mathrm{k})(4)(\mathrm{H})(\mathrm{iii}) ; 12$ C.F.R. $\S 225.172(\mathrm{a})$. 
may be necessary in order to obtain a reasonable return on investment upon resale or disposition. ${ }^{82}$

The requirement that a permissible merchant banking investment be made as part of a bona fide underwriting or investment banking activity imposes an important functional limitation on merchant banking activities. Even though an FHC is permitted to acquire full ownership of a purely commercial firm, the principal purpose of its investment must remain purely financial: making a profit upon subsequent resale or disposition of its ownership stake. ${ }^{83}$ The Board made clear that merchant banking authority was not designed to allow FHCs to enter the nonfinancial business conducted by any portfolio company. ${ }^{84}$ This explicitly stated statutory requirement "preserves the financial nature of merchant banking investment activities and helps further the ... purpose of maintaining the separation of banking and commerce."

Another important requirement that shapes the practical usefulness of the merchant banking authority to FHCs investing in commercial companies is the holding period for merchant banking investments, which is generally limited to a maximum of ten years. ${ }^{86}$ If the investment is made through a qualifying private equity fund, ${ }^{87}$ the maximum holding period is fifteen years. ${ }^{88}$ In certain exigent circumstances, the FHC may petition the Board to allow it to hold the investment for some limited time in excess of the applicable holding period ${ }^{89}$ Explicit limits on the duration of merchant banking investments underscore the principally financial nature of this activity.

Finally, the prohibition on FHCs' involvement in the routine management and operation of portfolio companies they own or control under the merchant banking authority is designed to serve as an additional safeguard against mixing banking and commerce. The Merchant Banking Rule lists the

82. 12 U.S.C. $\$ 1843(\mathrm{k})(4)(\mathrm{H})(\mathrm{iv}) ; 12$ C.F.R. $\$ 225.171(\mathrm{a})$.

83. Bank Holding Companies and Change in Bank Control, 66 Fed. Reg. $8,466,8,469$ (Jan. 31, 2001) (codified at 12 C.F.R. $\$ 225$ (2013)).

84. Id.

85. Id.

86. 12 C.F.R. $\S 225.172(b)(1)$.

87. Id. $\S 225.173(\mathrm{a})(1)-(5)$.

88. Id. $\S 225.173(\mathrm{c})(1)$.

89. Id. $\$ 225.172(b)(4)$. These extensions are meant to apply in situations where unfavorable market conditions or other circumstances would make it necessary or economically prudent for an FHC to temporarily postpone the resale or disposition of the investment. See $i d . \S 225.172(\mathrm{~b})(5)$. 
indicia of impermissible routine management or operation of a portfolio company, which include certain kinds of management interlocking ${ }^{90}$ and contractual restrictions on the portfolio company's ability to make routine business decisions, such as hiring non-executive officers or employees, or entering into transactions in the ordinary course of business. ${ }^{91}$ Arrangements that do not constitute routine management or operation of a portfolio company include contractual agreements restricting the portfolio company's ability to take actions not in the ordinary course of business; ${ }^{92}$ providing financial, investment, and management consulting advice to, and underwriting securities of, the portfolio company; ${ }^{93}$ and meeting with the company's employees to monitor or advise them in connection with the portfolio company's performance or activities. ${ }^{94}$ Importantly, the Merchant Banking Rule specifically allows an FHC to elect any or all of the directors of any portfolio company, as long as the board of directors does not participate in the routine management or operation of the portfolio company. ${ }^{95}$

90. Id. $\S 225.171(\mathrm{a}),(\mathrm{b})(1)$. An FHC is deemed to be engaged in the routine management or operation of a portfolio company if (1) any director, officer, or employee of the FHC or certain of its subsidiaries (including depository institutions, securities broker-dealers, and merchant banking subsidiaries) serves as, or has the responsibilities of, an executive officer of a portfolio company; or (2) any executive officer of the FHC or any of the same subsidiaries as mentioned above serves as, or has the responsibilities of, an officer or employee of the portfolio company. Id. $\S 225.171(\mathrm{~b})(1)$.

An FHC is presumed to be routinely managing or operating a portfolio company if:

(i) any director, officer, or employee of the $[\mathrm{FHC}]$ serves as or has the responsibilities of [a non-executive officer] or employee of the portfolio company; or (ii) [a]ny officer or employee of the portfolio company is supervised by any director, officer, or employee of the [FHC] (other than in that individual's capacity as a director of the portfolio company).

Id. $\$ 225.171(\mathrm{~b})(2)$. An FHC may rebut these presumptions by providing the Board with sufficient information showing the absence of routine management or operation. Id. \&225.171(c).

91. Id. § 225.171(b)(1).

92. Id. $\S 225.171(\mathrm{~d})(2)$.

93. Id. $\$ 225.171(\mathrm{~d})(3)(\mathrm{i})$, (ii).

94. Id. \& $225.171(\mathrm{~d})(3)(\mathrm{iii})$.

95. Id. $\S 225.171(\mathrm{~d})(1)$. The portfolio company must employ officers and employees responsible for routinely managing and operating its affairs. Id. $\S 225.171(\mathrm{~d})(1)(\mathrm{i})$. An FHC may engage, on a temporary basis, in the routine management or operation of a portfolio company only if such actions are necessary to save the economic value of the FHC's investment and to obtain a reasonable return on such investment upon its resale or disposition. 12 U.S.C. $\S 1843(\mathrm{k})(4)(\mathrm{H})(\mathrm{iii})(2012) ; 12$ C.F.R. § 225.171(e)(1). 
Despite their seemingly harsh tenor, these restrictions leave FHCs considerable flexibility in directing the affairs of their portfolio companies. The indicia of "routine management" focus mainly on specific personnel decisions and formalized arrangements ceding control over ordinary-course business decisions. Avoiding such formal indicia of "routinely managing" a portfolio company's daily affairs, while retaining control over important substantive aspects of its business, presents little difficulty. ${ }^{96}$ The real question is whether, in practice, FHCs comply with the formal requirements of the Merchant Banking Rule while circumventing its intended purpose by using merchant banking authority not to make purely financial investments in commercial companies but primarily as a means of engaging in impermissible commercial activities. ${ }^{97}$

\section{Pure Commerce: "Complementary" Powers}

As discussed above, the main justification for allowing FHCs to own or control commercial companies under the merchant banking authority is the notion of merchant banking as a fundamentally financial activity. However, the GLBA also contains a separate grant of authority for FHCs to conduct activities that are clearly not financial in nature but are determined by the Board to be "complementary" to a financial activity. ${ }^{98}$ The statute requires that the Board also determine that any such complementary activity "not pose a substantial risk to the safety or soundness of depository institutions or the financial system generally." ${ }^{99}$

Procedurally, the Board makes these determinations on a case-by-case basis. Any FHC seeking to acquire more than five percent of the voting securities of any class of a company engaged in any commercial activity that the FHC believes to be complementary to a financial activity must apply for the Board's prior approval by filing a written notice. ${ }^{100}$ In the no-

96. Similarly, the holding period limitation may not be a deal-breaker for an FHC seeking commercial investments: ten years can be a long time horizon in today's financial markets.

97. This is an empirical question that requires a qualitative analysis of individual FHC's use of merchant banking authority and the nature of its relationship with portfolio companies. It is not clear whether the Board currently collects such data.

98. 12 U.S.C. $\S 1843(k)(1)(B)$.

99. Id.

100. 12 C.F.R. $\$ 225.89$ (a) (2013). The FHC applies for approval by filing at least a sixty-day prior notice in accordance with section $4(j)$ of the BHCA. 12 
tice, the FHC must specifically describe the proposed commercial activity; identify the financial activity for which it would be complementary and provide detailed information sufficient to support a finding of "complementarity"; describe the scope and relative size of the proposed activity (as measured by the expected percentages of revenues and assets associated with the proposed activity); and discuss the risks the proposed commercial activity "may reasonably be expected" to pose to the safety and soundness of the FHC's deposit-taking subsidiaries along with the risk management measures the FHC would take to minimize such risks. ${ }^{10}$

The notice must also describe the public benefits that engaging in the proposed activity "reasonably can be expected to produce." ${ }^{102}$ In making its determination, the Board is required to make a specific finding that the proposed activity would produce public benefits that outweigh its potential adverse effects. ${ }^{103}$ The statutory list of such public benefits includes "greater convenience, increased competition, or gains in efficiency." 104 The Board must balance these benefits against such dangers as "undue concentration of resources, decreased or unfair competition, conflicts of interests, unsound banking practices, or risk to the stability of the United States banking or financial system., ${ }^{105}$

The legislative history of this provision shows that the industry deliberately sought the inclusion of the "complementary" clause as an open-ended source of legal authority for banking organizations to engage in any commercial activities that may become feasible or potentially profitable in the future. In congressional hearings, financial services industry representatives stressed "the importance of having the flexibility to engage in nominally commercial activities, particularly those related to technology and telecommunications, that support and complement [their] core business." ${ }^{106}$ This is how then Vice-Chairman

\footnotetext{
U.S.C. $\S 1843(\mathrm{j})(4)(\mathrm{A}) ; 12$ C.F.R. $\S 225.89$ (a).

101. 12 C.F.R. $\S 225.89$ (a)(1)-(5).

102. Id. § $225.89(\mathrm{a})(6)$.

103. Id. § $225.89(\mathrm{~b})(3)$.

104. 12 U.S.C. $\S 1843(\mathrm{j})(2)(\mathrm{A})$.

105. Id. This list essentially reiterates the policy concerns underlying the principle of separation of banking from commerce. See supra Part I.A.

106. The Financial Services Act of 1998: Hearing on H.R. 10 Before the S. Comm. on Banking, Hous., and Urban Affairs, 105th Cong. 172 (1998) (prepared statement of John G. Heimann, Chairman, Global Financial Institutions, Merrill Lynch \& Co., Inc., on behalf of the Financial Services Council).
} 
of J.P. Morgan \& Co. described the industry's vision of "complementary" business activities:

The world of finance has changed. Information services and technological delivery systems have become an integral part of the financial services business. Financial firms use overcapacity in their back office operations by offering services to others such as telephone help lines or data processing for commercial firms. These activities may not be strictly "financial," yet they utilize a financial firm's resources and complement its financial capabilities in a manner that is beneficial to the firm without adverse policy implications.

Financial firms also engage in activities that arguably might be considered non-financial, but which enhance their ability to sell financial products. One example is American Express, which publishes magazines of interest to its cardholders-Food \& Wine and Travel \& Leisure. Travel \& Leisure magazine is complementary to the travel business (an activity permitted within the definition of financial in H.R. 10) in that it gives customers travel ideas which the company hopes will lead to ticket purchases and other travel arrangements through American Express Travel Services. Similarly, Food \& Wine promotes dining out, as well as purchases of food and wine, all of which might lead to greater use of the American Express Card. These activities are complementary to financial business and thus should be permissible for financial holding companies. ${ }^{107}$

The industry's frequent references to Travel \& Leisure and Food \& Wine magazines effectively framed the congressional debate on "complementary" activities as a debate about relatively low-risk, low-profile activities, such as publishing and financial data dissemination. In reality, however, the possibility of having a flexible, undefined statutory category of permissible commercial activities was especially attractive to financial institutions seeking to take advantage of the dot-com boom and potentially expand into far riskier Internet ventures. ${ }^{108}$ From the industry's perspective, an intentionally open-ended "complementary" authority was the key to such an expansion. ${ }^{109}$

107. The Financial Services Modernization Act of 1999: Hearing on H.R. 10 Before the H. Comm. on Banking and Fin. Servs., 106th Cong. 294-95 (1999) (prepared testimony of Michael E. Patterson, Vice Chairman, J.P. Morgan \& Co., Inc., on behalf of the Financial Services Council).

108. As the CEO of Bank One Corp. put it, " $[t]$ he area on the commerce side that is most interesting to me is what is happening on the Internet." The Financial Services Modernization Act of 1999: Hearing on H.R. 10 Before the H. Comm. on Banking and Fin. Servs., 106th Cong. 18 (1999) (testimony of John B. McCoy, President and CEO, Bank One Corporation).

109. Straying from the magazine-publishing story line, Chairman and CEO of Merrill Lynch explained the industry's need for definitional flexibility as follows:

[O]ne of our concerns was . . to retain the ability to make investments in Silicon Valley for research and development and for access 
In April 1999, the Senate introduced its version of the reform bill that for the first time included the "complementary powers" provision. ${ }^{110}$ In June 1999, the House bill was amended to incorporate a similar authorization of "complementary" activities but only "to the extent that the amount of such complementary activities remains small in relation to the authorized activities to which they are complementary." 111 This express limitation disappeared from the final version enacted into law as part of the GLBA, leaving the Board free to set its own conditions for FHCs' complementary activities.

The Board has described the intended scope and purpose of its own authority to approve certain activities as complementary to an FHC's financial activity in relatively cautious terms, as allowing individual FHCs to do the following:

[T]o engage, to a limited extent, in activities that appear to be commercial if a meaningful connection exists between the proposed commercial activity and the FHC's financial activities and the proposed commercial activity would not pose undue risks to the safety and soundness of the FHC's affiliated depository institutions or the financial system. ${ }^{112}$

Curiously, between 2000 and 2012, the Board used its authority almost exclusively to approve physical commodity and energy trading activities as complementary to $\mathrm{FHCs}$ ' financial activity of trading in commodity derivatives. ${ }^{113}$ It seems that,

to systems and technology. If we had had this conversation three to five years ago, this would have been the furthest thing from our minds and something we certainly at that time would not been involved in nor had very much interest in being involved in.

The Financial Services Modernization Act of 1999: Hearing on H.R. 10 Before the H. Comm. on Banking and Fin. Servs., 106th Cong. 23-24 (1999) (testimony of David Komansky, Chairman and CEO, Merrill Lynch \& Co., Inc.).

110. S. 900, 106th Cong. $\S 102$ (1999) (as placed on the Senate calendar, Apr. 28, 1999). 'The Democratic members of the Senate's Banking Committee unanimously voted against the bill as significantly weakening the separation of banking and commerce. S. REP. No. 106-44, at 54, 73 (1999). They specifically criticized the Republican majority's new "complementary" clause as too open-ended and unnecessary. Id. at 75.

111. H.R. 10, 106th Cong. $\$ 102$ (1999) (as reported by H. Comm. on Banking \& Financial Services, June 15, 1999) (internal citations omitted). An earlier House Committee Report included a similar provision. See H.R. REP. NO. 106-74, pt. 1, at 5 (1999).

112. Bank Holding Companies and Change in Bank Control, 68 Fed. Reg. 68,493 (Dec. 9, 2003) (emphasis added).

113. See infra Part II.B. It appears that, as of mid-2013, the Board approved only one other type of activity - certain disease management and mailorder pharmacy services-as complementary to a financial activity of underwriting and selling health insurance. See 93 Fed. Res. Bull. C133-36 (2007). Wellpoint, which was not a BHC, submitted an application to the FDIC to ob- 
after the GLBA was enacted, FHCs discovered that trading crude oil and wholesale electricity "complemented" their traditional financial activities much better than publishing travel and culinary magazines. This phenomenon raises critical questions about the scope and practical operation of the undefined and intentionally broad statutory concept of "complementarity."

\section{A Special Kind of Commerce: Grandfathered Commodities} Activities

In addition to granting FHCs potentially broad and vaguely defined merchant banking and "complementary" powers, the GLBA contains a special grandfathering provision for commodities activities. ${ }^{114}$ Section 4(0) of the BHCA explicitly authorizes any company that becomes an FHC after November 12, 1999, to continue conducting "activities related to the trading, sale, or investment in commodities and underlying physical properties," ${ }^{115}$ subject to the following conditions:

(1) the company "lawfully was engaged, directly or indirectly, in any of such activities as of September 30, 1997, in the United States"; 116

(2) the aggregate consolidated assets of the company attributable to commodities or commodity-related activities, not otherwise permitted to be held by an FHC, do not exceed five percent of the company's total consolidated assets (or such higher percentage threshold as the Board may authorize); ${ }^{117}$ and

(3) the company does not permit cross-marketing of products and services between any of its subsidiaries engaged in the grandfathered commodities activities and any affiliated U.S. depository institution. ${ }^{118}$

This is a very curious provision that, to date, has remained

tain deposit insurance for its new Utah-chartered industrial bank. Id. at C133. Although owning an industrial bank would not make Wellpoint a BHC subject to the BHCA's activity restrictions, Wellpoint had to request the Board's determination because, at the time, the FDIC-imposed temporary moratorium on providing deposit insurance to new industrial banks prohibited approval of any such applications unless the applicant (Wellpoint, in this instance) engaged exclusively in FHC-permissible activities. See Moratorium on Certain Industrial Bank Applications and Notices, 72 Fed. Reg. 5,290 (Feb. 5, 2007).

114. See 12 U.S.C. $\$ 1843(0)$ (2012).

115. Id.

116. Id. § 1843(o)(1).

117. Id. § 1843(0)(2).

118. Id. $\$ 1843(\mathrm{o})(3)(\mathrm{A}),(\mathrm{B})$. 
largely unnoticed and rarely, if ever, invoked or discussed in public discourse or legal analysis. Yet, as discussed below, this provision is poised to become a potentially critical factor in redrawing the line between banking and commerce in the postcrisis era. ${ }^{119}$ The vague phrasing of this section seems to allow a qualifying new FHC to conduct not only virtually any kind of commodity trading but also any related commercial activities (for example, owning and operating oil terminals and metals warehouses), if it engaged in any commodities business-even if on a very limited basis and/or involving different kinds of commodities-prior to the 1997 cut-off date ${ }^{120}$ Potentially, such a broadly stated exemption may open the door for large financial institutions to conduct sizeable commercial activities of a kind typically not allowed for banking organizations. ${ }^{121}$

To date, the outer limits of the commodities grandfathering clause have not been tested. It is difficult to assess, therefore, whether and to what extent this seemingly inconspicuous provision may be used to deal the final death blow to the principle of separation of banking and commerce. The legislative history of this special grandfathering clause, however, provides valuable context in which to place analysis. It is also highly instructive from the point of view of the political economy of U.S. financial services regulation.

The grandfathering of pre-existing commodities trading activities was originally proposed in 1995 by Congressman Jim Leach as part of a broader set of provisions establishing a new charter for "wholesale financial institutions" (WFIs), which could conduct a wide range of banking activities but, importantly, could not take federally-insured retail deposits. ${ }^{122}$ Under the proposal, companies that owned or controlled one or more WFIs (but not FDIC-insured banks)-Wholesale Financial Holding Companies (WFHCs) - would be regulated and su-

119. See infra Part IV.A.1.

120. See 12 U.S.C. $\$ 1843(0)$.

121. The statutory five percent limit on the FHC's total consolidated assets attributable to the grandfathered commodities activities is designed to prevent a dramatic shift in the business profile of such an FHC from financial to purely commercial commodities activities. In absolute terms, however, even such a small fraction of total consolidated assets of a large FHC may allow for a considerable expansion of its commercial business of owning, producing, transporting, processing, and trading physical commodities. Such an expansion may very well implicate the fundamental policy concerns underlying the principle of separation of banking and commerce.

122. Financial Services Competitiveness Act of 1995, H.R. 1062, 104th Cong. $\S 109$ (1995) (version 1). 
pervised by the Board but less stringently than regular FHCs. ${ }^{123}$ These provisions of the House bill were designed specifically to create a so-called "two-way street" for investment banks to enable them to acquire commercial banks and offer their institutional clients wholesale banking services without becoming subject to the full range of activity restrictions under the BHCA. ${ }^{124}$ Because WFIs and their parent companiesdubbed "woofies"-would not have access to federal deposit insurance and, therefore, were not likely to pose any significant potential threat to the deposit insurance fund, the proposal authorized them to engage in a broader set of non-financial activities than regular FHCs backed by FDIC insurance. One of these explicit trade-offs involved the grandfathering of woofies' pre-existing commodities trading and related activities. ${ }^{125}$

Curiously, both Goldman and J.P. Morgan were among the big banks and securities firms that strongly pushed for the passage of the "woofie" charter. ${ }^{126}$ The proposal, however, became a subject of intense political contention in Congress. ${ }^{127}$ In contrast

123. Id. In the 1995 versions of the House bill, these WFI holding companies were referred to as "Investment Bank Holding Companies." Compare H.R. 1062, 104th Cong. $\$ 109$ (1995) (version 1), with H.R. 10, 105th Cong. $\$ 131$ (1998) (version 3, exemplifying the difference in terminology).

124. This is how an American Bankers Association report described the 1997 proposal:

To allow for two-way affiliations between banks and securities firms, a new type of holding company would be permitted. This would be the investment bank holding company. These companies would have still wider powers than the new bank holding company format would bring, but the separation between banking and commerce would still be retained. These special holding companies could own wholesale financial institutions (WFIs, also known as "woofies") which would be uninsured but also not subject to standard bank holding company firewalls.

Steve Cocheo, Outlook Brightens for New Banking Laws, 89 A.B.A. BANKING J. 10,10 (1997).

125. Goldman lobbied for specific inclusion of the commodity grandfathering clause in the "woofie" provisions of the House bill because of its existing investment in J. Aron, a commodity trading company. In fact, at the time, the commodity grandfathering provision was "widely viewed as the 'Goldman' exception." Martin E. Lybecker, Financial Holding Companies and Financial Activities Provisions of the Gramm-Leach-Bliley Act, in BACK TO THE FUNDAMENTALS: INSURANCE REGULATION, BROKER-DEALER REGULATION, AND INVESTMENT ADVISER REGULATION H-81 n.11 (ABA-CLE ed., 2001).

126. Dean Anason, Capital Briefs: Wholesale Banking Cut from Reform Bill, AM. BANKER, Oct. 28, 1999, at 2; Leslie Wayne, Push for Wholesale Banks Stalls in Overhaul of Law, N.Y. TIMES, July 7, 1999, at C2.

127. Some of the most intense battles arose out of the ideologically divisive issue of applicability of the Community Reinvestment Act (CRA) to "woofies." Ultimately, this controversy became one of the main reasons for defeating the 
to the House bill, the Senate version of the reform legislation did not contain "woofie" provisions. ${ }^{128}$ In April 1999, however, Senator Phil Gramm introduced an amendment that effectively replicated the commodity grandfathering provision for "woofies" in the House bill-but without any reference to "woofies." ${ }^{129}$ In the Conference, the entire subtitle of the House bill dealing with "woofies" was dropped. ${ }^{130}$ The Senate's broader version of the commodity-grandfathering clause, however, remained in the text of the GLBA and became the current section 4(o) of the BHCA. ${ }^{131}$ Thus, an initially limited concession to financial institutions that were explicitly denied access to federal deposit insurance became an open-ended exemption available to all newly-registered FHCs fully backed by the federal government guarantees. ${ }^{132}$

To sum up, the GLBA created significant opportunities for U.S. banking organizations to play a much more direct and active role in purely commercial sectors of the economy-and, especially, in energy and commodities markets. How did this legal and regulatory relaxation of the restrictions on mixing banking and commerce affect individual FHCs' actual business strategies? Did this country's biggest banking organizations take advantage of their new powers to break down this venerable wall? Or does the GLBA provide an effective framework for restraining the expansion of large financial conglomerates' commercial activities in practice? A closer look at U.S. FHCs' involvement in the trading of physical commodities provides a fascinating glimpse of possible answers to these questions.

\section{WHAT WE SEE: BANKING ORGANIZATIONS' ENTRY INTO PHYSICAL COMMODITIES AND ENERGY TRADING}

This Part examines the process of steady regulatory expan-

proposal. Dean Anason, Reform Panel Approves Packet of Resolutions, but Tough Issues Await, AM. BANKER, Sept. 30, 1999, at 2; Dean Anason, Reform Vote Called Off as Republicans Battle CRA, AM. BANKER, Sept. 4, 1998, at 1. The media also reported at the time that investment banks initially lobbying for the "woofie" charter, over time, lost interest in the concept, partly because some of them were acquired by large BHCs and others decided that the new legislation was evolving in a favorable direction even without the "woofie" provisions. See Wayne, supra note 126.

128. See S. 900, 106th Cong. (1999) (as placed on the Senate calendar, Apr. $28,1999)$.

129. S. REP. No. 106-44, at 3 (1999).

130. Anason, supra note 126 , at 2 .

131. See 12 U.S.C. $\$ 1843(0)$ (2012).

132. See id. 
sion of the scope of FHC-permissible activities in commodity and energy markets between the enactment of the GLBA and the onset of the global financial crisis in 2008. During this period, several large FHCs successfully obtained regulatory approvals to trade physical commodities as an activity complementary to commodity derivatives trading. ${ }^{133}$

Crucially, however, the system of regulatory reporting has not been updated to reflect these developments. Contrary to what one might expect, there is no meaningful public disclosure of banking organizations' assets and activities related to physical commodities and energy. Hence, it is important to preface the discussion by explaining why the American public does not yet have a full picture of what is happening in this space.

\section{A. WHY OUR VISION IS OBSCURED: A NOTE ON THE INFORMATIONAL GAP}

There are several reasons why the existing public disclosure regime is inadequate to assess the nature and scale of financial institutions' physical commodity trading operations.

The first difficulty is that publicly-traded financial institutions-including all of the largest FHCs-typically report their assets, revenues, profits, and other financial information for the entire business segment, of which commodities trading is only a part. For instance, Goldman includes commodities in its Fixed Income, Currencies and Commodities (FICC) division, which is included in the firm's Institutional Client Services business segment. ${ }^{134}$ The same is true of Morgan Stanley, which includes commodities operations in its Fixed Income and Commodities (FIC) division within the Institutional Securities business segment. ${ }^{135}$ Neither firm provides full financial infor-

133. See, e.g., Deutsche Bank AG, 92 Fed. Res. Bull. C54 (2006); Barclays Bank PLC, 90 Fed. Res. Bull. 511 (2004); UBS AG, 90 Fed. Res. Bull. 215 (2004).

134. Goldman Sachs Grp, Inc., Annual Report (Form 10-K), 1-4 (Feb. 28, 2012) [hereinafter Goldman Sachs Grp., Form 10-K]. The firm's Institutional Client Services activities are organized by asset class and include both "cash" and "derivative" instruments. Id. Cash instruments refer to trading in the assets underlying derivative contracts, such as "a stock, bond or barrel of oil." Id. at 3 . The firm's annual report does not provide details on their physical commodity operations and simply lists commodity products FICC trades: "Oil and natural gas, base, precious and other metals, electricity, coal, agricultural and other commodity products." Id. at 4 . The report states that FICC generally facilitates client transactions and makes markets in commodities. Id. at 115.

135. Morgan Stanley, Annual Report (Form 10-K), at 2-3 (Feb. 27, 2012) [hereinafter Morgan Stanley, Form 10-K]. According to the company's descrip- 
mation attributable specifically to its commodities divisions.

The second difficulty is that, to the extent FHCs include in their regulatory filings financial information specific to their commodities operations, such information usually pertains to both commodity-linked derivatives operations and trading in physical commodities. As a result, most financial information reported under the "commodities" rubric relates to the derivatives business, leaving one to guess what is going on in the firms' physical commodities businesses. ${ }^{136}$ Because of this reporting pattern, industry analysts' estimates of the revenues or profits generated by large FHCs' commodities trading desks often include the estimated revenues and profits from purely financial transactions in commodity derivatives. More broadly, this disclosure format tends to de-emphasize-and thus make even less visible - the fact that financial institutions often act not only as dealers in purely financial risk but also as traditional commodity merchants.

Currently, large FHCs are required to report to the Board, on a quarterly basis, only one financial metric directly related to their physical commodities operations: the gross market value of physical commodities in their trading inventory. ${ }^{137}$ These

tion of its activities:

The Company invests and makes markets in the spot, forward, physical derivatives and futures markets in several commodities, including metals (base and precious), agricultural products, crude oil, oil products, natural gas, electric power, emission credits, coal, freight, liquefied natural gas and related products and indices. The Company is a market-maker in exchange-traded options and futures and OTC options and swaps on commodities, and offers counterparties hedging programs relating to production, consumption, reserve/inventory management and structured transactions, including energy-contract securitizations and monetization. The Company is an electricity power marketer in the U.S. and owns electricity-generating facilities in the U.S. and Europe.

Id. at 3.

136. For example, in its financial statements for the quarterly period ended March 31, 2012, Goldman reported the revenue from commodities instruments (both derivative and non-derivative) as $\$ 471$ million, compared to $\$ 957$ million for the same period in 2011. Goldman Sachs Grp., Inc., Quarterly Report Pursuant to Section 13 or 15(d) of the Securities Exchange Act of 1934, For the Quarterly Period Ended March 31, 2012 (Form 10-Q), at 13 (May 9, 2012) [hereinafter Goldman Sachs Grp., Form 10-Q]. Similarly, Goldman reported the average daily Value at Risk (VaR) measure for the commodity prices risk category (including both financial and cash commodity instruments) as $\$ 26$ million for the three months ended March 31, 2012, compared to \$37 million for the same quarterly period in 2011. Id. at 155 .

137. See Consolidated Financial STATEMENTS FOR Holding COMPANIES-FR Y-9C, Schedule HC-D ("Trading Assets and Liabilities"), Item 
mandatorily reported data may provide at least a hint of the potential scale of these activities. For instance, a look at this line item in JPMC's filings reveals a significant growth in the market value of physical commodities the company holds for trading purposes. Thus, as of March 31, 2009, JPMC reported the gross fair value of physical commodities in its inventory as a relatively modest $\$ 3.7$ billion. ${ }^{138}$ By September 30,2009 , the amount had doubled to $\$ 7.9$ billion. ${ }^{139}$ By the end of 2009 , the number had further increased to slightly over $\$ 10$ billion. ${ }^{140} \mathrm{At}$ the end of 2010 , the reported amount reached above $\$ 21$ billion. ${ }^{141}$ As of December 31, 2011, JPMC reported the gross fair value of physical commodities in its inventory at approximately $\$ 26$ billion. ${ }^{142}$ As of March 31, 2012, the gross fair value of physical commodities in JPMC's inventory had slightly decreased to $\$ 17.2$ billion. ${ }^{143}$ At the end of 2012 , that number was $\$ 16.2$ billion. ${ }^{144}$

Morgan Stanley's regulatory filings show that, as of March 31,2009 , the gross fair value of physical commodities it held in inventory was slightly below $\$ 2.5$ billion. ${ }^{145}$ The reported value of this line item in Morgan Stanley's reports rapidly increased

M.9.a(2) ("Gross fair value of physical commodities held in inventory."). Form FR Y-9C is a quarterly report filed with the Board by BHCs with total consolidated assets of $\$ 500$ million or more, which the Board is authorized by statute to require. See 12 U.S.C. $\$ 1844$ (2012); 12 C.F.R. \& 225.5(b) (2013).

138. J.P. MORGan CHaSe \& Co., Consolidated Financial Statements FOR BANK HOLDING COMPANIES-FR Y-9C, Schedule HC-D, Item M.9.a(2) (Mar. 31, 2009).

139. J.P. MORgan Chase \& Co., Consolidated FinanCial Statements FOR BANK HOLDING COMPANIES-FR Y-9C, Schedule HC-D, Item M.9.a(2) (Sept. 30, 2009).

140. J.P. Morgan Chase \& Co., Consolidated Financlal Statements FOR BANK HOLDING COMPANIES-FR Y-9C, Schedule HC-D, Item M.9.a(2) (Dec. 31, 2009).

141. J.P. Morgan Chase \& Co., Consolidated Financial Statements FOR BANK HOLDING COMPANIES-FR Y-9C, Schedule HC-D, Item M.9.a(2) (Dec. 31, 2010).

142. J.P. Morgan Chase \& Co., Consolidated Financlal Statements FOR BANK HOLDING COMPANIES-FR Y-9C, Schedule HC-D, Item M.9.a(2) (Dec. 31, 2011).

143. J.P. Morgan Chase \& Co., Consolidated Financial Statements FOR BANK HOLDING COMPANIES-FR Y-9C, Schedule HC-D, Item M.9.a(2) (Mar. 31, 2012).

144. J.P. Morgan Chase \& Co., Consolidated Financlal Statements FOR BANK HOLDING COMPANIES-FR Y-9C, Schedule HC-D, Item M.9.a(2) (Dec. 31, 2012).

145. MoRgan STANLEY, Consolidated Financial STATEMENTS FOR BanK Holding COMPANIES-FR Y-9C, Schedule HC-D, Item M.9.a(2) (Mar. 31, 2009). 
to $\$ 10.3$ billion as of September $30,2011,{ }^{146}$ before going slightly down to approximately $\$ 9.6$ billion as of March $31,2012 .{ }^{1}$ At the end of 2012, the gross fair value of physical commodities in Morgan Stanley's inventory was about $\$ 7.3$ billion. ${ }^{14}$

Goldman's filings show more fluctuations in the gross fair value of physical commodities in the firm's inventory during the same three-year period. Specifically, as of March 31, 2009, Goldman reported $\$ 1.2$ billion in this line item. ${ }^{149}$ At the end of the next quarter, the number fell to $\$ 682$ million. ${ }^{150}$ It peaked at the end of 2010 at over $\$ 13$ billion. ${ }^{151}$ As of March 31, 2012, Goldman reported the gross fair value of its physical commodities inventory at $\$ 9.5$ billion. ${ }^{152}$ At the end of 2012 , Goldman's number rose to $\$ 11.7$ billion. ${ }^{153}$

As issuers of publicly traded securities, FHCs include the same data in their quarterly reports filed with the SEC. ${ }^{154}$ The gross market value of FHCs' physical commodity trading inventory, however, measures solely their current exposure to commodity price risk. ${ }^{155}$ It does not provide a full picture of these organizations' actual involvement in the business of producing,

146. MORGAN STANLEY, CONSOLIDATED FINANCIAL STATEMENTS FOR BANK HOLDING COMPANIES-FR Y-9C, Schedule HC-D, Item M.9.a(2) (Sept. 30, 2011).

147. MORgan STANLEy, CONSOLIDATED FinANCIAL STATEMENTS FOR BANK HOLDING COMPANIES-FR Y-9C, Schedule HC-D, Item M.9.a(2) (Mar. 31, 2012).

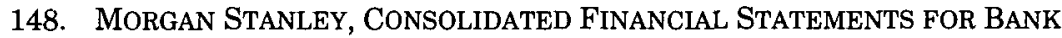
Holding COMPANIES-FR Y-9C, Schedule HC-D, Item M.9.a(2) (Dec. 31, 2012).

149. Goldman SACHS GRP., INC., Consolidated FinanCial StatementS FOR BANK HOLDING COMPANIES-FR Y-9C, Schedule HC-D, Item M.9.a(2) (Mar. 31, 2009).

150. GOLDMAN SACHS GRP., INC., CONSOlIDATEd FinanCial STATEMENTS FOR BANK HOLDING COMPANIES-FR Y-9C, Schedule HC-D, Item M.9.a(2) (June 30, 2009).

151. Goldman SaChs GrP., InC., Consolidated Financial Statements FOR BANK HOLDING COMPANIES-FR Y-9C, Schedule HC-D, Item M.9.a(2) (Dec. 31, 2010).

152. Goldman SaCHS GRP., INC., CONSOLIDATEd Financial Statements FOR BANK HOLDING COMPANIES-FR Y-9C, Schedule HC-D, Item M.9.a(2) (Mar. 31, 2012).

153. Goldman Sachs GrP., InC., Consolidated FinanCial Statements FOR BANK HOLDING COMPANIES, FR Y-9C, Schedule HC-D, Item M.9.a(2) (Dec. 31, 2012).

154. See, e.g., Goldman Sachs Grp., Form 10-Q, supra note 136, at 18.

155. Similarly, the VaR data included in FHCs' SEC filings provide a measure of their exposure to commodity price risk. See id. at 154 ("VaR is the potential loss in value of inventory positions due to adverse market movements over a defined time horizon with a specified confidence level."). 
extracting, processing, transporting, or storing physical commodities. To a great extent, this nearly exclusive regulatory focus on commodity price risk reflects the underlying assumption that U.S. banking organizations do not conduct any commodityrelated activities that could potentially pose any additional risks to their safety and soundness or create systemic vulnerabilities. If one assumes that banking organizations act only as arms' length buyers and sellers of physical commodities, strictly for the purpose of providing financial risk management services to their clients, then it is logical to conclude that sudden price fluctuations in commodity markets are the main source of potential risk from such activities. In the absence of detailed information on U.S. banking organizations' actual commodities assets and operations, however, this assumption becomes dangerously unreliable. ${ }^{156}$

Gaps in the current system of public disclosure and regulatory reporting explain the near-absence of reliable, detailed data on the precise nature and full scope of U.S. banking organizations' physical commodity operations. The traditional lack of transparency in global commodity markets and the inherently secretive nature of the commodity trading industry create a third source of difficulties for understanding what exactly U.S. FHCs do, and how significant their role is, in these markets. A handful of large, mostly Switzerland-based commodities trading houses-including Glencore, ${ }^{157}$ Vitol ${ }^{158}$ Trafigura,,${ }^{159}$ Mercuria, ${ }^{160}$ and Gunvor ${ }^{161}$-dominate the global trade in oil

156. There may be ways to collect some information on FHCs' physical commodities activities from a wide variety of diverse sources, including statistical records maintained by the Department of Energy (DOE), FERC, or other non-financial regulators. However, theoretical availability of these disparate data does not cure the fundamental informational deficiency in this area. Even if it can be located, with significant effort, such amalgamation of data is not likely to create a complete and reliable picture of large FHCs' commodity operations and assets.

157. Switzerland-based Glencore is the world's largest independent commodity trading company with significant production assets. See At a Glance, GLENCOREXSTRATA, http://www.glencorexstrata.com/about-us/at-a-glance (last visited Oct. 9, 2013).

158. Switzerland-based Vitol is one of the largest independent oil and gas trading companies in the world. See About Vitol, VITOL, http://www.vitol.com/ about-vitol.html (last visited Oct. 9, 2013).

159. See About $U_{s}$, TRAFIGURA, http://www.trafigura.com/about-us (last visited Oct. 9, 2013).

160. See Business Development, MERCURIA, http://www.mercuria.com/about -us/business-development (last visited Oct. 9, 2013).

161. Switzerland-based Gunvor is co-founded and co-owned by a Russian 
and gas, petroleum products, coal, metals, and other products. ${ }^{162}$ Nearly all of these publicity-shy commodities trading firms are privately owned. ${ }^{163}$ They do not publicly report results of their financial operations and generally refrain from disclosing information about the structure or performance of their investments. Secrecy has always been an important attribute of the traditional commodities trading business, in which access to information is vital to commercial success, and having informational advantage often translates into windfall profits. ${ }^{164}$ Given this lack of transparency and secretive nature of the commodities trading business, it is nearly impossible for an industry outsider-and even for most insiders-to gauge accurately the relative size and importance of U.S. FHCs as traders and dealers in the global markets for physical commodities. ${ }^{165}$

oil tycoon, Gennady Timchenko, whose reported close ties to Russia's President Putin gave rise to many speculations as to the true reasons for the company's success. See Dmitry Zhdannikov, "Gunvor, Putin and Me"-Oil Trader Speaks Out, REUTERS, May 22, 2008, available at http://www.reuters.com/ article/2008/05/22/us-putin-gunvor-idUSL228794620080522; From Petrograd to Petrodollars, THE ECONOMIST, May 5, 2012, http://www.economist.com node/21554184. See generally GUNVOR GROUP, http://gunvorgroup.com (last visited Oct. 9, 2013).

162. Javier Blas, Trading Houses: Veil Slowly Lifts on a Secretive Profession, Fin. TIMES, May 23, 2011, http://www.ft.com/intl/cms/s/0/f8028cb0-84cf -11e0-afcb-00144feabdc0.html\#axzz2dOuRafF9 Thereinafter Blas, Trading Houses].

163. Jack Farchy, Commodity Houses Court Outside Investors, FIN. TIMES, Apr. 24, 2012, http://www.ft.com/intl/cms/s/0/2b0b982c-8dee-11e1-bbae-00144f eab49a.html. A rare exception to this rule is Glencore, which became a publicly traded company in May 2011. See History, GLENCOREXSTRATA, http:// www.glencorexstrata.com/about-us/history (last visited Oct. 9, 2013).

164. Blas, Trading Houses, supra note 162.

165. This is especially true of oil and gas markets. Currently, the markets for trading crude oil and oil products are dominated by three groups of players: major oil companies (Royal Dutch Shell, Total, and British Petroleum), independent commodity trading houses (Vitol, Gunvor, Glencore, Trafigura, and Mercuria), and financial institutions (Morgan Stanley and Goldman). See GATI AL-JEBOURI, LITASCO SA, INTERNATIONAL OIL MARKETS AND OIL TRADING 6 (2008), available at http://www.litasco.com/_library/pdf/social_acts/ international_oil_market_and_oil_trading.pdf. Although these three types of oil traders have significantly different business structures and profiles, they have been converging in some important respects. Thus, the trading arms of oil majors and commodity trading houses have been developing active financial derivatives trading and dealing capabilities to supplement their traditional operations in physical markets. Recent media reports indicate that independent commodity trading companies have also been acquiring both upstream (oil production) assets and downstream (refining and processing) assets. See Javier Blas, Commodities Traders Face Growing Pains, FIN. TIMES, Apr. 26, 2012, http://www.ft.com/int//cms/s/0/3ae89836-8f78-11e1-9ab1-00144f eab49a.html\#axzz2dOuRafF9; Blas, Trading Houses, supra note 162. It is 
Nevertheless, even with these powerful blinders obscuring our vision, we can start tracing the path that led U.S. banking organizations to their current prominence in physical commodities markets. As it often happens in the banking world, the first step on that path was made possible by a seemingly routine regulatory agency action.

\section{B. LET'S Get PHYSICAL: THE SCOPE OF FHCS' "COMPLEMENTARY" POWERS}

Even before the enactment of the GLBA, U.S. commercial banks and their affiliates had become actively involved in trading and dealing in financial derivatives-publicly-traded futures and various over-the-counter contracts-linked to the prices of commodities. ${ }^{166}$ Since the mid-1980s, the OCC has been aggressively interpreting the bank powers clause of the National Bank Act to include derivatives trading and dealing as part of the "business of banking." BHCA, trading in commodity derivatives is generally treated as a financial activity that raises no controversial legal issues.

Handling physical commodities, however, was a much different matter. Even physical settlement of permissible commodity derivatives-which necessitated taking ownership, transporting, and storing actual crude oil or iron orepresented a problem in light of the general principle of separating banking from commerce. Despite industry lobbying, the Board refused to add the acceptance and delivery of physical commodities to the list of activities "closely related to banking" when it amended Regulation $\mathrm{Y}$ in $1997 .{ }^{168}$ By that time, the OCC was already allowing national banks to take delivery of physical commodities by warehouse receipt or on a "passthrough" basis, as part of hedging otherwise permissible com-

nearly impossible, however, to ascertain how big or important financial institutions' physical oil- and gas-trading operations are vis-à-vis the other two groups, in large part because that would require access to potentially sensitive non-public information on the oil companies' and trading houses' operations and activities. In an informal interview with the author, a professional oil industry consultant who wished to remain anonymous claimed that even a rough estimate would require a lot of sophisticated and prohibitively expensive investigative work not dissimilar to industrial espionage. For obvious reasons, such investigation does not appear to be feasible for the purposes of this Article.

166. See generally Omarova, supra note 30 .

167. Id.

168. FEIN, supra note $43, \S 18.07[6]$, at 18-38. 
modity derivatives transactions. ${ }^{169}$ The Board explained its reluctance to grant broad authority for BHCs to engage in physically settled commodity transactions by citing "issues involving risk management policies and procedures that are more appropriately addressed through the application review process."

In the early 2000 s, global commodities markets began experiencing a sharp and sustained rise in prices, building up to a major commodity boom. According to the World Bank, between 2003 and 2008, "[a]verage commodity prices doubled in U.S. dollar terms (in part boosted by dollar depreciation), making this boom longer and stronger than any boom in the 20th century." ${ }^{\prime 171}$ The beginning of this unprecedented commodity price boom coincided with the increased push by large U.S. financial institutions to establish large-scale physical commodity trading operations.

In 2003, the Board finally amended Regulation Y's "laundry list" of permissible non-banking activities to allow BHCs to accept or "make delivery of title to commodities underlying derivative contracts on an instantaneous, pass-through basis."172 The amended Regulation Y, however, imposes conditions on BHCs' authority to engage as principals in physically settled commodity derivatives, to ensure that a BHC would not take physical possession of the underlying commodity. ${ }^{173}$ These conditions reflect the Board's apparent unease with granting

169. Omarova, supra note 30 , at $1085-87$.

170. Federal Reserve System, 62 Fed. Reg. 9,290, 9,311-12 (Feb. 28, 1997) (codified at 12 C.F.R. \& 225 (2013).

171. The World BanK, Global Economic Prospects 2009: CommodiTIES AT THE CROSSROADS 51 (2009), available at http://siteresources .worldbank.org/INTGEP2009/Resources/10363_WebPDF-w47.pdf. Although commodity prices fell sharply in late 2008 as a result of the unfolding credit crisis, they recovered strongly between 2009 and 2011, rising almost to their peak 2008 levels. See THE WORLD BANK, GLOBAL ECONOMIC PROSPECTS JANUARY 2012, COMMODITY ANNEX 1 (2012), available at http://siteresources .worldbank.org/INTPROSPECTS/Resources/334934-1322593305595/8287139 -1326374900917/GEP2012A_Commodity_Appendix.pdf.

172. Federal Reserve System, 68 Fed. Reg. 39,807, 39,808 (July 3, 2003) (to be codified at 12 C.F.R. $\$ 225$ ).

173. Id. Regulation Y explicitly requires that a BHC either make every reasonable effort to avoid physical delivery or effect delivery by instantaneous transfer of title to a third party, without taking physical possession of the underlying commodity. 12 C.F.R. $\$ 225.28$ (b)(8) (2013). In addition, the derivative contract must allow for assignment, termination, or offset prior to delivery. Id. In the absence of such provisions, the contract must be approved for trading on a U.S. contract market (even though it may not be actually traded on any futures exchange) by the Commodity Futures Trading Commission (CFTC). Id. 
BHCs a blanket authority to engage in activities so closely resembling those of commodity merchants.

Thus, while trading in commodity derivatives is a financial activity permissible for FHCs, trading in the physical commodities underlying such derivatives transactions generally constitutes an impermissible commercial activity even in the postGLBA era. FHCs seeking to engage in physical trades must find a specific legal authority to do so. Just as the global commodity markets were entering the period of unprecedented price rises, several large U.S. FHCs and foreign banks successfully obtained Board orders allowing them to trade physical commodities as an activity complementary to the financial activity of trading and dealing in commodity derivatives.

\section{Permissible Physical Commodities Trading}

In 2003, Citigroup became the first to receive Board approval of its physical commodities trading as a "complementary" activity. ${ }^{174}$ Under the Board's order, Citigroup was allowed to purchase and sell oil, natural gas, agricultural products, and other non-financial commodities in the spot market and to take and make physical delivery of commodities to settle permissible commodity derivative transactions. ${ }^{175}$ The Board based its determination on four main considerations. First, the Board found that the proposed activities "flowed" from FHCs' legitimate financial activities, essentially providing them with an alternative method of fulfilling their obligations under otherwise permissible derivatives transactions. ${ }^{176}$ Second, permitting these activities would make FHCs more competitive vis-à-vis other financial firms not subject to regulatory restrictions on physically settled derivatives transactions. ${ }^{177}$ Third, the proposed activities would enable FHCs to offer a full range of commodity-related services to their clients in a more efficient manner. ${ }^{178}$ Finally, conducting physical commodity activities would enhance FHCs' understanding of the commodity derivatives market. ${ }^{179}$

174. Citigroup Inc., Order Approving Notice to Engage in Activities Complementary to a Financial Activity, 89 Fed. Res. Bull. 508 (2003) [hereinafter Citigroup Order].

175. Id.

176. Id. at 509 .

177. Id.

178. Id.

179. Id. 
To minimize the safety and soundness risks that this type of commercial activity may pose, the Board imposed a number of conditions on Citigroup's commodity-trading business. First, the market value of any commodities owned by Citigroup may not exceed five percent of its consolidated Tier 1 capital. ${ }^{180}$ This market value limitation is generally meant to ensure that physical commodity trading does not grow too big, at least in relative terms. ${ }^{181}$ Second, unless the Board specifically allows otherwise, Citigroup may take or make delivery only of those commodities for which derivatives contracts have been approved for trading on U.S. futures exchanges by the Commodity Futures Trading Commission (CFTC). ${ }^{182}$ This requirement was designed to prevent Citigroup from dealing in finished goods and other items, such as real estate, which lack the fungibility and liquidity of exchange-traded commodities. ${ }^{183}$ Third, the Board made clear that Citigroup must conduct its physical commodity trading business in compliance with the applicable securities, commodities, and energy laws. ${ }^{184}$

Finally, the Citigroup Order stated that the FHC was not "authorized to (i) own, operate, or invest in facilities for the extraction, transportation, storage, or distribution of commodities; or (ii) process, refine, or otherwise alter commodities." ${ }^{185}$ The expectation was that Citigroup would use storage and transportation facilities owned and operated by unrelated third parties. ${ }^{186}$ The purpose of this important limitation is to minimize non-financial risks inherent in physical commodity trading: storage risk, transportation risk, and potentially serious environmental and legal risks associated with these activi-

180. Id. If the market value of physical commodities held by Citigroup as a result of its commodity-trading activities exceeds four percent of its consolidated Tier 1 capital, Citigroup has to notify the Federal Reserve Bank of New York (FRBNY). In 2003, Citigroup reported its total consolidated Tier 1 capital of nearly $\$ 66.9$ billion. See Citigroup Inc., Annual Report (Form 10-K), at 89 (Dec. 31,2003 ). This puts the numerical limit for the market value of the physical commodities held by Citigroup for 2003 at slightly above $\$ 3.1$ billion. Id.

181. Citigroup Order, supra note 174, at 5. It is difficult to eliminate some degree of arbitrariness in setting this threshold, however. Generally, the "fivepercent" limit seems to be a particularly popular numerical marker that appears in various contexts in federal bank regulation. It is not entirely clear why this magic number is especially reasonable in any particular context.

182. Id.

183. Id. at 6 .

184. Id. at 8

185. Id.

186. Id. at 7 . 
ties. ${ }^{187}$ The Board relied on specific representations from Citigroup to the effect that it would exercise heightened care in avoiding these non-financial risks. Thus, Citigroup represented that it would require the owner of any vessel carrying oil on behalf of Citigroup to carry the maximum insurance for oil pollution available from a protection and indemnity club and to obtain a substantial amount of additional pollution insurance ${ }^{188}$ Similarly, it promised to require all third-party storage facilities to carry a significant amount of oil pollution insurance from a creditworthy insurance company. ${ }^{189}$ Citigroup would also place age limitations on vessels and develop a comprehensive backup plan in the event any owner of a vessel or storage facility fails to respond adequately to an oil spill. ${ }^{190}$

In subsequent years, the Board granted similar orders authorizing physical commodity trading activities on the part of FHCs and foreign banks treated as FHCs for purposes of the BHCA. These grants of complementary powers allowed large non-U.S. banks-such as UBS, ${ }^{191}$ Barclays, ${ }^{192}$ Deutsche Bank, ${ }^{193}$ and Société Générale ${ }^{194}$ - to expand their worldwide physical commodities businesses by adding U.S. operations, albeit on a somewhat limited scale. In 2005, JPMC also obtained an order permitting the $\mathrm{FHC}$ to engage in physical commodity trading activities as complementary to its booming financial derivatives business. ${ }^{195}$ In all of these cases, the Board imposed the same standard set of conditions and limitations originally articulated in the Citigroup Order.

In 2008, The Royal Bank of Scotland (RBS), then the U.K.'s largest banking group, received the Board's order authorizing a

187. Id. at 6. For example, one can imagine a situation in which an explosion aboard an oil tanker, owned or operated by one of Citigroup's subsidiaries, results in multiple human injuries and deaths, loss of property, failure to fulfill contractual obligations to third parties, and significant environmental damage-all of which would expose Citigroup to private lawsuits, regulatory enforcement actions, and even criminal liability.

188. Id. at 7 .

189. Id.

190. Id.

191. UBS AG, 90 Fed. Res. Bull. 215 (2004).

192. Barclays Bank PLC, 90 Fed. Res. Bull. 511 (2004).

193. Deutsche Bank AG, 92 Fed. Res. Bull. C54 (2006).

194. Société Générale, 92 Fed. Res. Bull. C113 (2006).

195. J.P. Morgan Chase \& Co., 92 Fed. Res. Bull. C57 (2006). Bank of America and Wachovia received Board approvals to conduct physical commodities trading in 2006-07. See Letter from Board to Bank of Am. Corp. (Apr. 24, 2007); Letter from Board to Wachovia Corp. (Apr. 13, 2006). 
wide range of physical commodities and energy trading activities as complementary to RBS's financial derivatives activities. ${ }^{196}$ RBS sought these expanded powers in connection with its acquisition of a fifty-one percent equity stake in a joint venture with Sempra Energy, a U.S. utility group. ${ }^{197}$ The joint venture, RBS Sempra Commodities (RBS Sempra), was set up to conduct a worldwide business of trading in various physical commodities-including oil, natural gas, coal, and non-precious metals-and be an active player in power markets in Asia and North America. ${ }^{198}$

In the RBS Order, the Board significantly relaxed the standard limitations and expanded the scope of permissible trading in physical commodities. Thus, the Board allowed RBS to take and make physical deliveries of nickel, even though nickel futures were not approved for trading on U.S. futures exchanges by the CFTC. The Board reasoned that contracts for nickel were actively traded on the LME, a major non-U.S. exchange subject to regulation comparable to the regulation of the U.S. futures exchanges. ${ }^{199}$ The Board also authorized physical trading in a long list of physical commodities-including natural gasoline, asphalt, kerosene, and other oil products and petrochemicals-despite the fact that contracts for these commodities have not been approved for trading on any major exchange. ${ }^{200}$ In authorizing physical trading in these commodities, the Board relied on the fact that these commodities were fungible and that contracts for them were traded in sufficiently liquid over-the-counter markets (through individual brokers and on alternative trading platforms). ${ }^{201}$

Although previous orders prohibited FHCs from refining or processing commodities they traded, the Board authorized RBS to hire third parties to refine, blend, or otherwise alter the commodities. ${ }^{202}$ In effect, this removed the ambiguity in previous orders by explicitly allowing RBS, for example, to sell crude

196. The Royal Bank of Scotland Grp. plc, 94 Fed. Res. Bull. C60 (2008) [hereinafter RBS Order].

197. Philip Aldrick, RBS Buys Majority Stake in Sempra, TELEGRAPH, Jul. 10, 2007, http://www.telegraph.co.uk/finance/markets/2811893/RBS-buys -majority-stake-in-Sempra.html.

198. Id.

199. RBS Order, supra note 196, at C62-C63.

200. Id.

201. Id. "Fungibility" means that market participants contract for stated quantities but cannot specify the exact product or lot they want to receive. Id.

202. Id. at $\mathrm{C} 61$. 
oil to an oil refinery and then buy back the refined oil product. The Board determined that this activity essentially posed the same risks as hiring a third party to operate a storage or transportation facility, as permitted under previous orders. ${ }^{203}$ In addition, RBS made a specific commitment that it would not have exclusive rights to use the alteration facility. ${ }^{204}$

The Board also authorized RBS to enter into long-term electricity supply contracts with large industrial and commercial customers. The Board noted that, while most commodities traded by FHCs were limited to wholesale markets, electric power could much more easily reach small retail customers. ${ }^{205}$ To ensure that RBS remained a wholesale electric power intermediary dealing only with sophisticated customers, the RBS Order specified the minimum consumption levels for customers to whom RBS was allowed to sell electricity on a long-term basis. ${ }^{206}$

\section{Energy Management and Energy Tolling}

The RBS Order is especially noteworthy as an example of a large FHC expanding the scope and nature of its energy business beyond the traditional model of buying and selling commodities. In the RBS Order and in two separate orders issued to a Belgian-Dutch bank, Fortis, the Board specifically approved so-called energy management and energy tolling services they sought to perform in the United States. ${ }^{20}$

These orders authorized RBS and Fortis to provide certain energy management services-consisting of transactional and advisory services-to owners of power generation facilities under Energy Management Agreements (EMA). ${ }^{208}$ FHCpermissible energy management services generally entail acting as a financial intermediary for a power plant owner to facilitate purchases of fuel and sales of power by the plant, as well as advising the owner on risk-management strategies. ${ }^{209}$ Thus, the energy manager-Fortis or RBS-would buy fuel for the

203. Id. at $\mathrm{C} 64$.

204. Id. at $\mathrm{C} 67$.

205. Id. at $\mathrm{C} 64$.

206. Id.

207. Fortis S.A./N.V., 94 Fed. Res. Bull. C20 (2008) [hereinafter Fortis Order]; RBS Order, supra note 196; Letter from Board to Fortis S.A/N.V. (May 21,2008 ) [hereinafter Fortis Board Letter].

208. See Fortis Order, supra note 207, at C20.

209. Id. 
plant from third parties and sell it to the plant in a mirror transaction. It would then purchase the power generated by the plant and resell it in the market. ${ }^{210}$ In effect, the energy manager would provide credit and liquidity support for the plant owner, including the posting of any required collateral for transactions. ${ }^{211}$ In addition, the manager also would assume responsibility for administrative tasks in connection with, and the hedging of exposure under, fuel and power transactions. ${ }^{212}$

FHC-permissible energy management services, however, are subject to several conditions designed to limit the safety and soundness risks of such activities. Thus, the Board required that the revenues attributable to the FHC's energy management services not exceed five percent of its total consolidated operating revenues. ${ }^{213}$ The Board also required that all EMAs, pursuant to which the FHC engages in these activities, include certain mandatory provisions. For example, the EMA must mandate that the plant owner approve all contracts for purchases of fuel and sales of electricity, although the owner may be allowed to grant a standing authorization to the manager to enter into contracts that meet certain owner-specified criteria. ${ }^{214}$ The owner must retain responsibility for the day-today maintenance and management of the power generation facility, including hiring employees to operate it. The owner must also retain the right to (i) market and sell power directly to third parties, although the manager may have the right of first refusal; and (ii) determine the facility's power output level at any given time. ${ }^{215}$ In addition, the FHC is prohibited, directly or through its subsidiaries, from guaranteeing the financial performance of the power plant and from bearing any risk of loss if the plant is not profitable. ${ }^{216}$

Energy tolling is generally similar to energy management. The Board authorized RBS and Fortis to enter into energy toll-

210. Id. at C21.

211. Id.

212. The administrative tasks include, among other things, arranging for third parties to provide fuel transportation or power transmission services, coordinating fuel purchases and power sales, negotiating and monitoring contracts with the plant owner's counterparties. See Fortis Order, supra note 207.

213. Id. at $\mathrm{C} 22$. This revenue limit is the functional equivalent of the market value limit the Board imposed on physical commodities activities.

214. Id.

215. Id.

216. Id. 
ing agreements that have certain characteristics. ${ }^{217}$ Under these arrangements, an FHC (the toller) makes fixed periodic (usually, monthly) "capacity payments" to the power plant owner, to compensate the owner for its fixed costs, in exchange for the right to all or part of the plant's power output. ${ }^{218}$ The plant owner retains control over the day-to-day operation of the power plant. The toller pays for the fuel needed to produce the power it directs the owner to produce. The owner receives a marginal payment for each megawatt hour produced by the plant, as compensation for its variable costs plus a profit margin. ${ }^{219}$ As the Board explained it, the toll is:

similar to a call option on the power produced by the plant with a strike price linked to fuel and power prices. In general, the toller would direct the operator to run the plant (i.e., the toller would exercise its option) when the price of power exceeds the cost of producing that amount of power. Some tolling agreements may also give the toller the right to a plant's excess capacity, which the toller may sell to the market or use to meet reliability obligations to the power grid. ${ }^{220}$

The Board approved energy tolling as a complementary activity because it is an "outgrowth" of the relevant FHC's permissible commodity derivatives activities. ${ }^{221}$ It reasoned that permitting energy tolling would provide the $\mathrm{FHC}$ with valuable information on the energy markets, which would help it to manage its own commodity risk. It would also allow the FHC to compete more effectively with other financial firms not subject to the BHCA.

\section{THE BOUNDARIES OF "COMPLEMENTARITY"}

An overview of the Board's grants of complementary powers to FHCs to engage in physical commodities and energy trading activities reveals an inherent flaw in the regulatory concept of "complementarity" that, in effect, fails to impose meaningful limits on the expansion of banking organizations' commercial businesses.

Under the Board's pre-crisis decisions, the main limitation on FHCs' complementary powers to engage in physical commodities and energy activities is the regulatory requirement that FHCs not own, operate, or invest in the facilities for extraction, transportation, storage, and distribution of commodi-

217. See RBS Order, supra note 196; Fortis Board Letter, supra note 207.

218. See RBS Order, supra note 196, at C64.

219. Id.

220. Id. (internal formatting omitted).

221. Id. at $\mathrm{C} 65$. 
ties. Under these orders, FHCs generally have to lease, rent, or charter such facilities. It appears that this is where the Board draws the line, out of its (at this point, apparently residual) concern about allowing FHCs to get directly involved in purely commercial activities. The Fortis and RBS Orders, however, raise an interesting question about the real impact of this prohibition. Thus, the energy management and tolling arrangements described in these orders look very much like the functional equivalent of owning a power generating facility. Even with all of the Board-mandated contractual provisions guaranteeing a certain role for the plant owner, these agreements give the FHCs control over the plant's operation and output. In effect, the FHC obtains a contractually captive power generator, which allows it to build or expand its business supplying electricity under long-term contracts in wholesale power markets.

How "complementary" would this type of wholesale power marketing business be to any financial activity of RBS or Fortis? As the Board emphasized, a complementary activity must have some "meaningful connection" to a bona fide financial activity of an FHC, and a grant of complementary powers must enable the FHC to engage in commercial activities only "to a limited extent." ${ }^{222}$ The Board approved these energy trading activities and other physical commodities trading because they naturally "flow" or "grow out of" the BHC-permissible electricity and commodity-linked derivatives trading. ${ }^{223}$ Yet, this argument is too superficial to be convincing. Any number of commercial activities can be connected to trading and dealing in derivatives, by virtue of the simple fact that derivatives can be linked to any asset. ${ }^{224}$ That this type of "complementarity" is

222. Bank Holding Companies and Change in Bank Control, 68 Fed. Reg. 68,493 (Dec. 9, 2003).

223. Id.

224. For example, if an FHC trades in weather derivatives, does that mean the FHC can also build and operate satellites and radar systems used in meteorological forecasting as a complementary activity? Can that FHC also own construction companies that build homes able to withstand severe storms in hurricane-prone areas? Conveniently, the same FHC, through a bank subsidiary, can also provide financing to purchasers of such homes and perhaps insure those homes and securitize the loans. These would be purely financial activities that could serve as a starting point for a new set of the FHC's "complementary" commercial business activities. The same logic may be applied to envision a new chain of commercial and financial activities plausibly connected to derivatives referencing a different asset category. At some point, a list of commercial activities potentially related to some form of a derivative product would probably grow to encompass the entire universe of economic enterprise. 
used to justify banking organizations' direct involvement in power generation and marketing reveals something very important about the role of derivatives trading as a bankpermissible activity. Trading and dealing in these infinitely malleable instruments, which effectively translate every economic value into quantifiable financial risk, seems to have created an instant set of potential synergies with every conceivable economic activity. Taken at face value, the familiar arguments about the benefits to the banking institutions of being able to engage in commercial activities that "naturally" flow out of their derivatives activities raise a fundamental policy question: if such connection is truly necessary, should banking institutions be allowed to trade in derivatives? To put it boldly, may unlimited trading and dealing in derivatives-or, at least, certain kinds of derivatives-be potentially inconsistent with the principle of separating banking from commerce? Although these complex policy issues are beyond the scope of this Article, they highlight a critical flaw in the amorphous notion of "complementarity."

It is worth noting that FHCs began actively seeking expanded authority to conduct physical commodities and energy trading activities in the early 2000 s-soon after the fall of Enron, the pioneer in financializing commodity and energy markets. ${ }^{225}$ It is difficult to draw definitive conclusions as to whether there is a direct causal connection between these phenomena. Yet, one can identify at least one key link in this respect: the rise, in the wake of Enron's failure, of Goldman and Morgan Stanley, then independent investment banks, as top players in global markets for physical commodities and energy. Their preeminence as commodity derivatives dealers and access to cheap and plentiful credit and liquidity gave Goldman and Morgan Stanley key advantage over large energy companies that attempted to replicate Enron's initial success. ${ }^{226}$ These two firms, which at the time were not subject to the BHCA's activity restrictions, were also Citigroup's and JPMC's main competitors in the commodity derivatives space. ${ }^{227}$ In authorizing

225. Shiela McNulty, Speculators Return in Wake of Enron, FIN. TIMES, Dec. 1, 2011, http://www.ft.com/intl/cms/s/0/24cd3dcc-1b74-11e1-8647-00144fe abdc0.html\#axzz2gX8IEQC5.

226. Large energy companies, including Dynegy and Duke Energy, tried to follow Enron's model by combining large-scale physical and derivatives trading but failed due mainly to capital constraints and limited access to credit necessary for sustaining it. $I d$.

227. Id. 
FHCs to trade in physical commodities, the Board meant to remedy their competitive disadvantage vis-à-vis Goldman and Morgan Stanley.

Of course, before the autumn of 2008 , nobody could imagine that both of these institutions would voluntarily become BHCs, in the midst of a major financial crisis-and that their conversion would bring the salience of U.S. banking institutions' commodity trading activities to a whole new level.

\section{WHAT WE DON'T (YET) SEE: HOW THE CRISIS CHANGED THE PHYSICAL COMMODITIES TRADING GAME}

One of the most profound and least appreciated consequences of the recent financial crisis is the emergence of a powerful trio of large FHCs with extensive physical commodities business operations: Morgan Stanley, Goldman, and JPMC. Two extraordinary crisis-driven phenomena led to this result: the emergency conversion of Morgan Stanley and Goldman into BHCs and the once-in-a-lifetime acquisition by JPMC of the commodity assets of two failing institutions, Bear Stearns and RBS.

On September 21, 2008, Morgan Stanley and Goldman received approval to register as BHCs subject to the Board's regulation and supervision, in a desperate effort to bolster investor confidence and avoid potential creditor run on their assets. ${ }^{228}$ In the midst of the unfolding crisis, the Board approved these firms' applications to become BHCs almost literally overnight, without putting them through its normal, lengthy and detailed review process. It is highly unlikely that, at the time of the conversion, the Board focused on these firms' extensive physical commodities assets and activities-or gave full consideration to the question of how to deal with such activities in the long run.

JPMC followed a different route to the top of the Wall Street commodities game. In 2008 , the firm acquired the physical commodity trading assets of failing Bear Stearns. ${ }^{229}$ In 20092010, JPMC bought the global commodities business of nation-

228. See Goldman Sachs Grp., Inc., 94 Fed. Res. Bull. C101, C102, 2008 WL 7861871, at*4 (Nov. 1, 2008); Morgan Stanley, 94 Fed. Res. Bull. C103, C105, 2008 WL 7861872 , at $* 5$ (Sept. 21,2008 ).

229. Morgan Stanley May Sell Part of Commods Unit: CNBC, REUTERS, June 6, 2012, available at http://www.reuters.com/article/2012/06/06/us -morganstanley-commodities-idUSBRE8550ND20120606 [hereinafter CNBC]. 
alized RBS. ${ }^{230}$ In a few short years, the firm's aggressive growth strategy transformed it into one of the three biggest U.S. banking organizations dominating global commodity markets. ${ }^{231}$

Thus, in the wake of the financial crisis, the Board finds itself facing a qualitatively different commodities business conducted by three of the largest U.S. banking organizations. Under the BHCA, a newly-registered BHC has up to five years from the registration date either to divest its impermissible non-banking activities or to bring such activities into compliance with BHCA requirements. ${ }^{232}$ The statutory five-year grace period for the non-conforming commodity activities of Goldman and Morgan Stanley ends in the fall of 2013, at which point the Board must make a potentially fateful decision whether these firms will be able to continue-and further expand-their commodity and energy merchant businesses. This decision, however, requires a thorough understanding of the nature and scope of these institutions' actual involvement in physical commodities and energy markets.

As discussed above, general news and business media reports remain the main source of publicly available information on FHCs' activities in physical commodities and energy markets. ${ }^{233}$ Based primarily on the analysis and synthesis of media reports, the following sections describe what is publicly known about the nature and scope of the physical commodities activities of the three FHCs with the largest presence in that space: Morgan Stanley, Goldman, and JPMC.

\section{A. MoRgan Stanley and Goldman SACHS: Playing FOR THE NEW CLUB}

Prior to their emergency conversion into BHCs in September 2008, Goldman and Morgan Stanley were independent investment banks with extensive equity investments in various commercial businesses. ${ }^{234}$ Even among their peers, however, Goldman and Morgan Stanley stood out as the "original 'Wall Street refiners' that pioneered the modern energy derivatives

230. Id.

231. Id. Among non-U.S. financial institutions, only UK's Barclays and Germany's Deutsche Bank currently compete with Morgan Stanley, Goldman and JPMC in global commodity markets. Id.

232. 12 U.S.C. $\S 1843(a)(2)(2012)$.

233. See supra Part II.A.

234. CNBC, supra note 229. 
market two decades ago." ${ }^{235}$ In addition to their dominant position as major dealers in commodities derivatives, both firms have established themselves as the key players in the production, processing, transportation, storage, and trading of a wide range of physical commodities. ${ }^{23}$

Both Morgan Stanley and Goldman began actively expanding their physical commodity operations in the early $2000 \mathrm{~s}$, in response to the commodity price boom. ${ }^{237}$ There are two main reasons for this expansion. First, direct participation in the production and marketing of physical commodities yields crucial informational advantages for these firms' derivatives trading business. ${ }^{238}$ Continuous access to inside information on current price trends in the commodity spot markets enhances their ability to price and trade commodity-linked derivatives in the most profitable ways. Physical assets-pipelines, tankers, terminals, and warehouses-are "invaluable tools for traders." According to a former Morgan Stanley trader, "[i]t's as if you are a traffic cop sitting in the middle of an intersection, you see everything go by." ${ }^{240}$

Second, the steady upward trend in global commodities prices since the early 2000 s, going hand in hand with the increasing flow of financial investors' money into the sector, made physical commodity trading potentially a lucrative business in its own right. ${ }^{241}$ Buying, selling, storing, and moving commodities can generate handsome profits in a world that depends on the flow of these commodities for its very survival.

In practice, it is difficult to separate these two rationales for a firm like Goldman or Morgan Stanley to get involved in global commodity trading business. Until recently, the two firms seemed to pursue relatively different strategies in this area. Throughout the $1990 \mathrm{~s}$, Goldman focused primarily on commodity-linked derivatives, while Morgan Stanley built strong physical commodities trading operations. ${ }^{242}$ The latest

235. Id.

236. Id.

237. Jeanine Prezioso, Morgan Stanley Latest US Bank to Lose Traders to Merchant Firm, REUTERS, Sept. 6, 2012, available at http://www.reuters.com/ article/2012/09/06/morganstanley-mercuria-traders-idUSL2E8K67QA2012 0906.

238. Id.

239. Id.

240. Id.

241. Id.

242. Javier Blas, Commodities Trading Loses Its Goldman Queen, FTN. 
commodity price boom made these differences less meaningful, as Goldman moved aggressively into the physical space. ${ }^{243}$

Even after becoming FHCs subject to the BHCA, Goldman and Morgan Stanley remain the top players in both derivatives and physical commodity markets. ${ }^{244}$ This change in their regulatory status, however, fundamentally altered the broader context of U.S. bank holding company regulation and elevated to a new, previously unseen level the inherent tension between the principle of separation of banking and commerce, on the one hand, and the reality of large FHCs' growing commercial empires, on the other.

\section{Morgan Stanley: Oil, Tankers, and Pipelines}

During the years preceding the latest financial crisis, Morgan Stanley built a significant business trading in oil, gas, electric power, metals, and other commodity products. ${ }^{245}$ According to industry estimates, Morgan Stanley's commodities unit generated $\$ 17$ billion in revenue over the past decade, trading both financial contracts and physical commodities. ${ }^{246}$ Unlike its archrival Goldman, however, Morgan Stanley "has remained resolutely a merchant-trader, focusing on the business of storing or transporting raw materials." ${ }^{247}$ According to a 2008 research report, traditional client "flow" business-marketmaking, selling indices to investors, and commodity risk hedging-constituted only about ten to fifteen percent of the firm's commodities activities. ${ }^{248}$ About half of Morgan Stanley's commodities business is reportedly in crude oil and oil products, while about forty percent is in power and gas. ${ }^{249}$

Morgan Stanley has been using physical assets in trading

TIMES, Jan. 12, 2012, http://www.ft.com/intl/cms/s/0/ec8af7f0-3d02-11e1-ae07 -00144feabdc0.html\#axzz2eJIq1WUk.

243. Id.

244. See, e.g., GREENWICH ASSOCIATES, 2012 GREENwICH LEADERS: OTC COMMODITIES DERIVATIVES (2012); Alexander Osipovich, Risk and Energy Risk-2012 Commodity Rankings-Energy, RISK.NET (Feb. 9, 2012), http:// www.risk.net/energy-risk/research/2144918/risk-energy-commodity-rankings -2012-energy.

245. CNBC, supra note 229.

246. Id.

247. Matthew Robinson \& Scott DiSavino, Deal or No Deal, Morgan Stanley Commodity Trade Shrinks, REUTERS, Jun. 7. 2012, available at http://www .reuters.com/article/2012/06/07/morganstanley-commodities-idUSL1E8H757V 20120607.

248. Id.

249. Id. 
energy and commodities since the mid-1980s. ${ }^{250}$ In the early 1990 s, Morgan Stanley's oil trader, Olav Refvik, struck deals to buy and deliver oil and oil products to large commercial users around the globe and earned the nickname "King of New York Harbor" for accumulating a record number of leases on storage tanks at the key import hub, which gave the firm a great market advantage. ${ }^{251}$ During the same period, Morgan Stanley constructed power plants in Georgia, Alabama and Nevada, which allowed it to become a major electricity seller. ${ }^{252}$

In the mid-2000s, Morgan Stanley began aggressively expanding its energy infrastructure investments, especially in oil and gas transportation and logistics. In 2006, Morgan Stanley acquired full ownership of Heidmar Inc., a Connecticut-based global operator of commercial oil tankers. ${ }^{253}$ Although Morgan Stanley sold fifty-one percent of equity in 2008 , it still retained a forty-nine percent stake. ${ }^{254}$ Heidmar operates a fleet of more than 100 double-hull vessels and provides transportation and logistics services to major oil companies around the world. ${ }^{255}$

In September 2006, Morgan Stanley acquired, in a leveraged buyout, the full ownership of TransMontaigne Inc., a Denver-based oil-products transportation and distribution company. ${ }^{256}$ TransMontaigne markets "unbranded gasoline, diesel fuel, heating oil, marine fuels, jet fuels, crude oil, residual fuel oils, asphalt, chemicals and fertilizers." ${ }^{257}$ The company is affiliated with a fuel terminal facility operator, TransMontaigne Partners L.P., which operates oil terminals in twentyseven U.S. states and Canada. ${ }^{258}$ In 2005, the last year TransMontaigne was a publicly-listed company, it reported revenues of about $\$ 8.6$ billion and assets of slightly less than $\$ 1.2$ bil-

250. Ann Davis, Morgan Stanley Trades Energy Old-Fashioned Way: In Barrels, WALl ST. J., Mar. 2, 2005, at A1.

251. Id.

252. Id.

253. Company History, HEIDMAR, http://www.heidmar.com/history (last visited Oct. 9, 2013).

254. Id.

255. What We Do: Commercial Management, HEIDMAR, http://www .heidmar.com/what-we-do (last visited Oct. 9, 2013).

256. TRANSMONTAIGNE PARTNERS L.P., 1,750,000 COMMON UNITS REPRESENTING LiMiTED PARTNER INTERESTS S-2 (Prospectus Supp. 2010).

257. About TMG, TRANSMONTAIGNE, http://www.transmontaigne.com/ about-tmg (last visited Oct. 9, 2013).

258. TransMontaigne is the general partner of TransMontaigne Partners L.P., a publicly-traded Delaware limited partnership. Id. 
lion. ${ }^{259}$ Forbes estimated the company's 2011 revenues at $\$ 12$ billion. ${ }^{260}$

Both Heidmar and TransMontaigne are subsidiaries of Morgan Stanley Capital Group Inc. (MS Capital Group), Morgan Stanley's commodities and energy trading arm through which it holds equity stakes in multiple commodity businesses. ${ }^{261}$ According to Morgan Stanley's own description of its physical commodities business activities in its SEC filings:

In connection with the commodities activities in our Institutional Securities business segment, we engage in the production, storage, transportation, marketing and trading of several commodities, including metals (base and precious), agricultural products, crude oil, oil products, natural gas, electric power, emission credits, coal, freight, liquefied natural gas and related products and indices. In addition, we are an electricity power marketer in the U.S. and own electricity generating facilities in the U.S. and Europe; we own TransMontaigne Inc. and its subsidiaries, a group of companies operating in the refined petroleum products marketing and distribution business; and we own a minority interest in Heidmar Holdings LLC, which owns a group of companies that provide international marine transportation and U.S. marine logistics services. ${ }^{262}$

The SEC filings of TransMontaigne Partners, the only publicly-traded subsidiary of MS Capital Group and TransMontaigne, provide a fascinatingly detailed picture of one significant facet of Morgan Stanley's physical commodities business: "oil terminaling and transportation." ners owns and operates a vast infrastructure, including numerous crude oil and refined products pipelines and terminals along the Gulf Coast, in the Midwest, in Texas, along the Mississippi and Ohio Rivers, and in the Southeast. ${ }^{264}$ The company receives refined oil products and liquefied natural gas from customers via marine vessels, ground transportation, or pipelines; stores customers' products in its tanks located at the terminals; monitors the volume of stored products in its tanks; provides

259. See Fortune 500 2006, CNN MONEY, http://money.cnn.com/magazines/ fortune/fortune500/snapshots/1452.html (last visited Oct. 9, 2013) (ranking America's largest corporations).

260. \#21 TransMontaigne, FORBES, http://www.forbes.com/lists/2011/21/ private-companies-11_TransMontaigne_7I0O.html (last visited Oct. 9, 2013) (excluding the revenues generated by the company's publicly-traded subsidiaries).

261. Morgan Stanley, Form 10-K, supra note 135, at exh. 21.

262. Id. at 27.

263. TransMontaigne Partners L.P., Annual Report (Form 10-K), at 10-11

(Mar. 13, 2012) [hereinafter TransMontaigne Partners, Form 10-K].

264. Id. at 12-19. 
product heating and mixing services; and transports the refined products out of its terminals for further distribution. ${ }^{265}$

In 2011, TransMontaigne Partners earned over $\$ 152$ million in revenues, of which almost $\$ 107$ million came from its affiliates. ${ }^{266}$ The company's primary customers are its indirect parent entities, MS Capital Group and TransMontaigne ${ }^{267}$ This is how the company's latest annual report describes the business activities of MS Capital Group:

Morgan Stanley Capital Group is a leading global commodity trader involved in proprietary and counterparty-driven trading in numerous commodities markets including crude oil and refined products, natural gas and natural gas liquids, coal, electric power, base and precious metals and others. Morgan Stanley Capital Group has been actively trading crude oil and refined products for over 20 years and on a daily basis trades millions of barrels of physical crude oil and refined products and exchange-traded and over-the-counter crude oil and refined product derivative instruments. Morgan Stanley Capital Group also invests as principal in acquisitions that complement Morgan Stanley's commodity trading activities. Morgan Stanley Capital Group has substantial strategic long-term storage capacity located on all three coasts of the United States, in Northwest Europe and Asia. ${ }^{268}$

TransMontaigne Partners' SEC filings offer a rare glimpse into Morgan Stanley's sprawling network of assets and activities in the energy sector. Ownership of critical infrastructure assets-including terminals, pipelines, and marine vesselsgreatly facilitates Morgan Stanley's trading of energy and

265. Id. at 12-13.

266. TransMontaigne Partners L.P., Annual Report (Form 10-K/A), at 73 (Apr. 30, 2012), available at http://sec.gov/Archives/edgar/data/1319229/00010 4746912005319/a2208753z10-ka.htm\#aa3.

267. TransMontaigne Partners, Form 10-K, supra note 263, at 18.

268. Id. The report describes TransMontaigne's own business operations as follows:

TransMontaigne Inc. is a terminaling, distribution and marketing company that markets refined petroleum products to wholesalers, distributors and industrial and commercial end users throughout the United States, primarily in the Gulf Coast, Northeast, Southeast and Midwest regions. TransMontaigne Inc. also owns a 100\% interest in TransMontaigne Canada Holdings, Inc., a Canadian petroleum marketing and terminaling company. As of December 31, 2011, TransMontaigne Inc. owned three refined product terminals; one dry bulk product terminal; three railcar facilities; a hydrant system in Port Everglades; and its distribution and marketing business. TransMontaigne Inc.'s marketing operations generally consist of the distribution and marketing of refined products through contract and rack spot Id. sales in the physical markets. 
commodities, in both physical and derivatives markets. ${ }^{269}$ At the same time, such a direct and active involvement in the business of oil and gas processing, storage, and transportation creates significant risks for Morgan Stanley. Global energy prices are notoriously volatile and depend on a complex interplay of various factors, including geopolitical ones. More importantly, however, these activities expose the firm to potential legal liability, financial loss, and reputational damage in the event of industrial accidents, oil spills, explosions, terrorist acts, or other catastrophic events that cause serious environmental harms. ${ }^{270}$ It is difficult to quantify the extent of this risk, especially in the case of potential large-scale environmental disaster, but it is not difficult to imagine that it may be potentially fatal even for a large company with a formidable balance sheet. For a financial institution whose main business depends greatly on its reputation and market perceptions of the quality of its credit, even a remote risk of such an event may be too much to live with. Morgan Stanley's public disclosure of this particular risk factor is carefully crafted and perfectly understated:

269. In July 2011, TransMontaigne Partners entered into an agreement for construction and operation of a new crude oil storage facility in Cushing, Oklahoma, the major delivery hub and price settlement point for the benchmark West Texas Intermediate (WTI) crude. Id. at 14. MS Capital Group's access to this strategically located facility is likely to give it significant additional advantage in trading oil futures and OTC derivatives referencing WTI. Id. The company's public filings stated:

We will lease a portion of land in Cushing, OK and construct storage tanks and associated infrastructure on that property for the receipt of crude oil by truck and pipeline, the blending of crude oil and the storage of 1.0 million barrels of crude oil. We have entered into a longterm services agreement with Morgan Stanley Capital Group Inc. for Id. the use of the facility.

270. According to Morgan Stanley's own description of the risk factors specific to its physical commodities business in its annual report:

As a result of these activities, we are subject to extensive and evolving energy, commodities, environmental, health and safety and other governmental laws and regulations. In addition, liability may be incurred without regard to fault under certain environmental laws and regulations for the remediation of contaminated areas. Further, through these activities we are exposed to regulatory, physical and certain indirect risks associated with climate change. Our commodities business also exposes us to the risk of unforeseen and catastrophic events, including natural disasters, leaks, spills, explosions, release of toxic substances, fires, accidents on land and at sea, wars, and terrorist attacks that could result in personal injuries, loss of life, property damage, and suspension of operations.

Morgan Stanley, Form 10-K, supra note 135, at 27. 
Although we have attempted to mitigate our pollution and other environmental risks by, among other measures, adopting appropriate policies and procedures for power plant operations, monitoring the quality of petroleum storage facilities and transport vessels and implementing emergency response programs, these actions may not prove adequate to address every contingency. In addition, insurance covering some of these risks may not be available, and the proceeds, if any, from insurance recovery may not be adequate to cover liabilities with respect to particular incidents. As a result, our financial condition, results of operations and cash flows may be adversely affected by these events. ${ }^{271}$

The business must be worth the risk.

\section{Goldman Sachs: Metals, Warehouses, and Other Things}

It is particularly difficult to develop a sufficiently full picture of the true nature and extent of Goldman's involvement in the production, processing, transportation, and marketing of physical commodities. ${ }^{272}$ Wall Street's biggest commodities dealer (by revenues), Goldman is "credited with attracting the investors to the asset class with the creation of the Goldman Sachs Commodity Index in 1991." ${ }^{273}$ According to industry estimates, the firm's commodities business-including derivatives and physical trading-generated annual revenues of $\$ 3-4$

\section{Id.}

272. Unlike Morgan Stanley, Goldman does not appear to have publiclytraded subsidiaries engaged in physical commodities business, which eliminates the most lucrative source of reliable public information. In its SEC filings, Goldman provides only a brief description of commodities activities conducted by the firm's Institutional Client Services segment. See Goldman Sachs Grp., Form 10-K, supra note 134, at 3. Intriguingly, however, Goldman also reports proprietary, long-term investments in physical commodities assets in another business segment, Investing and Lending:

Our other investments primarily include our consolidated investment entities, which are entities we hold for investment purposes strictly for capital appreciation. These entities have a defined exit strategy and are engaged in activities that are not closely related to our principal businesses. We also invest directly in distressed assets, currencies, commodities and other assets, including power generation facilities.

$I d$. at 5 . It appears that this business segment includes private equity investments held by Goldman under the merchant banking authority. It is not clear whether the commodities and power generation facilities mentioned in the last sentence are held as the same kind of passive private equity investments. It does not appear that the value of these commodity assets is included in the reported market value of commodities in the firm's trading inventory.

273. Jack Farchy, Goldman and Clive Capital to Launch Commodities Index, FIN. TIMES, June 12, 2011, http://www.ft.com/int $1 / \mathrm{cms} / \mathrm{s} / 0 /$ acedcabe -9514-11e0-a648-00144feab49a.html\#axzz2dIS9LaYk. 


\section{billion between 2006 and $2008 .^{274}$}

Goldman's commodities trading business goes back to at least 1981, when the firm bought its principal commodities trading subsidiary, J. Aron \& Co., which originally specialized mostly in trading futures and options on precious metals and coffee. ${ }^{275}$ In the $1980 \mathrm{~s}-90 \mathrm{~s}$, Goldman focused primarily on client-driven financial transactions in commodities and built a dominant position in the energy futures and OTC derivatives markets. In the first decade of this century, however, Goldman "has also been expanding into physical commodities, with ventures into coal and shipping trading, and a bigger presence in physical metals such as aluminum."2i6

For example, in early 2005, the press reported that Goldman had "recently bought 30 electricity-generating plants." At least in part, this may have been a reference to Goldman's 2003 acquisition of Cogentrix Energy LLC, a major power producer based in Charlotte, North Carolina. ${ }^{278}$ At the time, Cogentrix owned and operated 26 coal- and natural gas-fired power plants. ${ }^{279}$

During the same period, Goldman reportedly made significant acquisitions in the oil and gas sector, including a significant stake in Kinder Morgan, Inc. (KMI), a major oil transportation and terminaling company that was recently reported to control approximately 37,000 miles of pipelines and 180 terminals handling crude oil, natural gas, and refined petroleum

274. Blas, Commodities Trading Loses, supra note 242.

275. J. Aron \& Co. Reduces Staff, N.Y. TIMES, Aug. 19, 1983, http://www .nytimes.com/1983/08/19/business/j-aron-co-reduces-staff.html. Both Goldman's CEO Lloyd Blankfein and President Gary Cohn started their careers at J. Aron \& Co.

276. Blas, Commodities Trading Loses, supra note 242.

277. Davis, supra note 250.

278. Goldman to Sell Power Plant Unit to Carlyle, REUTERS, Sept. 7, 2012, available at $\mathrm{http} / / \mathrm{www}$.reuters.com/article/2012/09/07/cogentrixenergy-carlyle -idUSL4E8K73S320120907.

279. Ryan Dezember, Carlyle to Acquire Cogentrix from Goldman, WALL ST. J., Sept. 7, 2012, http://online.wsj.com/article/SB1000087239639044381940 4577636172770944192.html. According to media, "Goldman sold off most of those plants-and built and sold others-during the last decade as Cogentrix transformed into more of a developer of power plants." Id. In September 2012, Goldman reportedly agreed to sell Cogentrix to a private equity firm, Carlyle Group L.P., on undisclosed terms. Id.; see also Ben Protess, Carlyle Buys Power Plants from Goldman Sachs, N.Y. TIMES, Sept. 7, 2012, http://dealbook .nytimes.com/2012/09/07/carlyle-buys-power-plants-from-goldman/? pagewanted=print. 
products. ${ }^{280}$ According to KMI's SEC filings, at the end of 2011, Goldman owned $19.1 \%$ of the company's common stock. ${ }^{281}$ In addition, the report listed each of the two managing directors of Goldman who also served on KMI's board of directors as holders of $19.1 \%$ of the company's common stock. ${ }^{282}$ It appears that Goldman has similarly structured private equity investments in other energy companies, including Cobalt International Energy Inc. (CIE), a Houston-based deep-water oil exploration and production company. ${ }^{283}$

Even after becoming an FHC subject to the activities restrictions of the BHCA and the consolidated supervision by the Board, Goldman continued to acquire significant hard assets in the commodities sector. For instance, in May 2012, the Financial Times reported that Goldman made a $\$ 407$ million deal with Brazil's Vale, to acquire full ownership of Vale's Colombian coal assets, including the El Hatillo coal mine, Cerro Largo coal deposit, and a coal port facility on Colombia's Atlantic

280. Kinder Morgan, Inc., Annual Report (Form 10-K), at 5 (Feb. 22, 2012). In investing in KMI, Goldman was joined by two private equity partners, The Carlyle Group (Carlyle) and Riverstone Holdings LLC (Riverstone). Press Release, The Carlyle Grp., Management Grp. and Inv. Partners Propose to Take Kinder Morgan, Inc. "Private" at $\$ 100$ Per Share (May 28, 2006), available at https://carlyle.com/news-room/news-release-archive/management-group-and -investment-partners-propose-take-kinder-morgan-inc-pr.

281. Goldman Sachs Grp., Form 10-K, supra note 134, at 121-22. Goldman held this aggregate equity stake through several controlled funds, which means that only a part of this investment was made with the firm's own capital, alongside its clients' money. Id. at 122.

282. Id. at 122. It is difficult to ascertain whether and to what extent this ownership structure and board membership gave Goldman effective control over KMI's management and operations. Nevertheless, it is a plausible view of the arrangement. It is particularly noteworthy that one of these two individuals on KMI's board of directors, Henry Cornell, was the Chief Operating Officer of Goldman's Merchant Banking division, while the other, Kenneth Pontarelli, was a managing director in the same division. Id. at 103-04. Thus, it appears that, for regulatory purposes, Goldman treated its investment in KMI as a merchant banking investment permissible to FHCs under the BHCA. In the context of Goldman's overall commodities trading business, however, one may legitimately question whether Goldman's stake in KMI was truly a passive, purely financial investment made solely for the purpose of reselling it at a profit.

283. Goldman holds a common equity stake in CIE through several controlled funds, and two of its managing directors in the merchant banking division serve on CIE's board. Cobalt Int'l Energy Inc., Proxy Statement (Schedule $14 \mathrm{~A}$ ), at 10-17 (Mar. 22, 2012). The firm originally invested in CIE in partnership with Carlyle and Riverstone. Cobalt Int'l Energy Inc., Annual Report (Form 10-K), at 108 (Feb. 21, 2012). 
coast. ${ }^{284}$ In addition, the deal included an $8.43 \%$ equity stake in the railway connecting the coal mines to the port. ${ }^{265}$ In addition to increasing Goldman's coal mining capacity, the deal was meant to improve access to the port and railway for its existing mines. ${ }^{286}$

Goldman owns and operates its coal mining assets in Colombia through a local subsidiary, Colombian Natural Resources. ${ }^{287}$ The firm holds its interest in Colombian Natural Resources indirectly, through another wholly-owned subsidiary, GS Power Holdings LLC. ${ }^{288}$ GS Power Holdings also holds another prized asset in Goldman's commodities empire: Metro International Trade Services LLC (Metro). ${ }^{289}$

Metro is a metals warehousing company that owns and operates nineteen warehouses in the Detroit metropolitan area, as well as warehousing facilities in Europe and Asia. ${ }^{290}$ By acquiring Metro in February 2010, Goldman gained control of one of the largest metals warehouses in the global network of storage facilities approved by the LME. ${ }^{291}$ This acquisition strategically positioned the firm in the middle of the global metals trading chain. Storing large quantities of metal generates lucrative rental income for warehousing companies like Metro. The warehousing business is particularly profitable during economic downturns when slackening demand forces producers to hold more of their commodity inventories in storage. ${ }^{292}$ Not surprisingly, Goldman was not the only commodity trader that rushed to acquire large LME-approved warehouses in the wake of the global financial crisis. ${ }^{299}$ The recent entry of financial in-

284. Joe Leahy, Goldman in Deal to Buy Vale's Coal Assets, FIN. TIMES, May 28, 2012, http://www.ft.com/intl/cms/s/0/c23288d0-a8e4-11e1-be59-00144 feabdc0.html\#axzz2dIS9LaYk.

285. Id.

286. Id.

287. Id.

288. See Goldman Sachs Grp., Form 10-K, supra note 134, at exh. 21.1.

289. Id.

290. Walsh, supra note 2.

291. Trefis Team, Metal Warehousing Pays Off for Goldman Sachs, FORBES, July 8, 2011, http://www.forbes.com/sites/greatspeculations/2011/07/ 08/metal-warehousing-pays-off-for-goldman-sachs/print.

292. Javier Blas, Goldman and JPMorgan Enter Metal Warehousing, FIN. TIMES, Mar. 2, 2010, http://www.ft.com/int $/ \mathrm{cms} / \mathrm{s} / 0 / 5025 \mathrm{f} 2 \mathrm{a}$-262e-11df-aff3 -00144feabdc0.html\#axzz2dIS9LaYk.

293. Glencore bought metals warehousing assets of Italy-based Pacorini Group, while JPMC acquired the UK-based Henry Bath as part of its purchase of RBS Sempra's commodities assets. Tatyana Shumski \& Andrea Hotter, 
stitutions effectively turned this traditionally low-profile industry run by dispersed independent operators into yet "another arm of Wall Street." ${ }^{294}$

This transformation has caused serious turbulence in the global market for aluminum, the second most widely-used metal in the world after steel. ${ }^{295}$ Aluminum producers store their metal in LME-approved warehouses and then sell their metal to industrial users. The buyers claim their purchased quantities of aluminum from the warehouse, which must deliver it to the specific buyer. ${ }^{296}$ Ownership of the key LME warehouses by large commodity traders with integrated financial and physical metals operations allows them to control the supply of aluminum to commercial users and, as a result, to control prices. ${ }^{297}$ This led other market participants to worry about unfair advantages for such firms, as they now can use their knowledge of how much metal is stored, as well as their ability to control delivery of physical metal to consumers, to determine their own trading strategies. ${ }^{298}$

Wall Street Gets Eyed in Metal Squeeze, WaLL ST. J., June 17, 2011, http:// online.wsj.com/article/SB10001424052702304186404576389680225394642

.html.

294. Id.

295. Jack Farchy, Banks Force Aluminium Market Shake-Up, FIN. TIMES, Sept. 12, 2012, http://www.ft.com/intl/cms/s/0/c3b3e02e-fcf3-11e1-a4f2-00144fe abdc0.html\#axzz2dIS9LaYk.

The arrival of investment banks in the aluminium market has triggered a shake-up in the $\$ 100 \mathrm{bn}$ industry that is forcing producers from Alcoa to Rusal and consumers such as BMW and Coca-Cola to change the way they do business. The increasingly dominant role of banks including Goldman Sachs, JPMorgan and Deutsche Bank-as well as traders such as Glencore-has prompted a surge to record levels in the premium consumers pay for metal over the benchmark price Id. set at the London Metal Exchange.

296. See Shumsky \& Hotter, supra note 293. The LME rules set the minimum delivery rates for its warehouses. If the demand for delivery of aluminum out of a particular warehouse significantly exceeds the rate at which the warehousing company actually releases it, the resulting bottleneck prevents the industrial users of aluminum from getting their purchased metal. Id.

297. Financial institutions like Goldman Sachs can also use their warehouses to store vast quantities of physical metals in so-called "financing" deals. This strategy allows financial institutions to secure a guaranteed return. Removing a large portion of physical metal from the market, however, creates artificial shortages of aluminum for commercial purchase and inflates its market price. See Farchy, supra note 295. To take full advantage of these opportunities, financial institutions that own large warehouses often offer monetary incentives to producers who store their metal in their facilities. Id.

298. Andrea Hotter, LME Doubles Minimum Metal Deliveries in Detroit, WALL ST. J., July 15, 2011, http://www.marketwatch.com/story/lme-doubles 
Goldman and its subsidiary Metro became the key figures in a recent ugly battle over global aluminum prices. In mid2011, Metro reportedly stored nearly a half of the global inventories of the industrial aluminum. ${ }^{299}$ Months-long delivery delays at the firm's storage facilities in Detroit caused much discontent among big commercial users of aluminum, such as the soft-drink giant Coca-Cola and the aluminum sheet-maker Novelis. ${ }^{300}$ In mid-2011, Coca-Cola filed a complaint with the LME alleging that Goldman intentionally limited the releases of aluminum from its Metro-operated warehouses in order to inflate the price of aluminum. ${ }^{301}$ In addition to potentially enabling Goldman to sell its own aluminum at artificially inflated prices, holding aluminum in the warehouse generates additional fees for Metro, as the buyers have to pay for each day their purchased metal stays in the warehouse.

In response to these complaints, the LME doubled the minimum delivery rates for large warehouses, including Metro. ${ }^{303}$ Nevertheless, warehousing bottlenecks and record-high aluminum premiums continued to wreak havoc in global aluminum markets throughout $2012^{304}$ and $2013 .^{305} \mathrm{By}$ mid-2013, the re-

-minimum-metal-deliveries-in-detroit-2011-07-15/print?guid=C5A329C8 -0E58-4AA7-AA2C-72ADCFA5AE65.

299. See Trefis Team, supra note 291; see also Pratima Desai et al., Goldman's New Money Machine: Warehouses, REUTERS, July 29, 2011, available at http:/www.reuters.com/assets/print?aid=USTRE76R3YZ20110729 (stating that, in the first six months of 2011, "Metro warehouses in Detroit took in 364,175 tonnes of aluminum and delivered out 171,350 tonnes [which] represented 42 percent of inventory arrivals globally and 26 percent of the metal delivered out").

300. See Shumsky \& Hotter, supra note 293.

301. Coca-Cola alleged that it had to wait for seven months for Metro to release its aluminum. See Walsh, supra note 290.

302. See Desai et al., supra note 299; Trefis Team, supra note 291.

Goldman charges 42 cents to store a metric ton of aluminum in its facilities for a day, which translates into $\$ 150$ in annual revenues for every metric ton it stores. With millions of tons in storage, the industry is expected to rake in $\$ 1$ billion in storage revenues each year. Goldman Sachs which is estimated to hold 900,000 tons in its facilities can make $\$ 138$ million in revenues from its storage business alone.

Trefis Team, supra note 291.

303. See Hotter, supra note 298 (explaining that under the new LME rule, beginning in April 2012, Metro had to deliver out at least 3,000 metric tons of aluminum daily).

304. See Jack Farchy, Aluminium Market's Premium Problem, Fin. TIMES, Sept. 14, 2012, http://www.ft.com/intl/cms/s/0/c04c50f6-fdc5-11e1-8fc3-00144fe abdc0.html\#axzz2dIS9LaYk ("Japanese premiums for the fourth quarter are settling at about $\$ 255$ a tonne-more than double the level of six months 
ported waiting time for aluminum in Detroit was longer than 460 days. ${ }^{306}$ In July 2013, the LME's new leadership proposed another change to its rules to require warehouses experiencing logjams to deliver out more metal than they take in. ${ }^{307}$ The new rule, however, is expected to become effective only starting in April 2014, which means continuing supply-chain disruptions and inflated prices for nearly another year. ${ }^{308}$ Not surprisingly, Goldman remains the key target of wholesale aluminum consumers' anger. ${ }^{309}$

\section{B. THE RISE OF JPMC: How Not TO WASTE A CRISIS}

Unlike Morgan Stanley and Goldman, JPMC has always been a regulated $\mathrm{BHC}$ subject to activity restrictions. In 2005, JPMC received the Board's approval to trade physical commodities as an activity "complementary" to its commodity derivatives business. ${ }^{310}$ Under the terms of the Board's approval, however, JPMC did not have legal authority to "own, operate, or invest in [any physical assets or] facilities for the extraction, transportation, storage, or distribution of commodities." ${ }^{311}$ These conditions reflected the Board's judgment with respect to the outer boundaries of FHC-permissible involvement in these purely commercial activities. ${ }^{312}$ In effect, the Board's decisions permit FHCs like JPMC to own hard assets in the physical commodities marketing chain, only as passive merchant bank-

ago-and producers and traders are talking about premiums of $\$ 320-\$ 330$ a tonne for European metal for the first quarter of next year.").

305. Jack Farchy, HKEx's LME Warehousing Conundrum, FIN. TIMES, June 10, 2013, http://www.ft.com/intl/cms/s/0/3fad0594-d10f-11e2-a3ea-00144 feab7de.html\#axzz2dIS9LaYk.

306. Laura Clarke \& Matt Day, New Stab at Metals Gridlock, WALL ST. J., July 2, 2013, at C4.

307. Id.; see also Jack Farchy, LME Takes Aim at Warehousing Queues, FIN. TIMES, July 1, 2013, http://www.ft.com/intl/cms/s/0/5988476c-e235-11e2 -a7fa-00144feabdc0.html\#axzz2dIS9LaYk.

308. Clarke \& Day, supra note 306 , at C1.

309. Farchy, Aluminium Market's, supra note 304. Aluminum end-users' complaints could potentially translate into legal action against the firm on antitrust grounds. In the fall of 2012, newspapers quoted Bob Bernstein, a New York lawyer representing commodities consumers, as saying that the dominant position of Goldman's warehousing subsidiary in LME's Detroit hub "naturally raises concerns about competition and the monopoly rents that are being charged." Id. This Article does not purport to assess the merits of any such claim.

310. See supra note 195 and accompanying text.

311. See id.

312. See supra Part II. 
ing investments.

The financial crisis became the key turning point for JPMC, which emerged from it significantly larger and even more systemically important than it had been before the crisis. In 2008, JPMC bought, at a steep discount, the key assets of Bear Stearns, an independent investment bank on the verge of failure ${ }^{313}$ As part of the deal, JPMC acquired commodity trading assets and operations, including a significant network of electric power generating facilities owned by Arroyo Energy Investors L.P. (Arroyo), a commodities subsidiary of Bear Stearns. ${ }^{314}$

After acquiring Bear's energy assets, JPMC's CEO Jamie Dimon and the head of commodities operations Blythe Masters began aggressively expanding the firm's physical commodities business. ${ }^{315}$ In 2008 , the firm started trading physical oil and looking at "more ways to boost its presence in energy markets." ${ }^{316}$ In addition to hiring more people in its commodities and energy trading and investment team, JPMC started drawing plans for strategically expanding its metals and energy operations in Asia. ${ }^{317}$

JPMC's once-in-a-lifetime chance to become a major player in commodities came in late 2009, when the European Commission ordered nationalized RBS to divest its riskier assets, ${ }^{318}$

313. Robin Sidel et al., J.P. Morgan Buys Bear in Fire Sale, as Fed Widens Credit to Avert Crisis, WALl ST. J., Mar. 17, 2008, at A1.

314. See id.; Linette Lopez, How the Financial Crisis Helped Turn Big Banks into Global Commodities Kings, BUS. INSIDER (Aug. 3, 2012, 9:25 AM), $\mathrm{http}: / / \mathrm{www}$.businessinsider.com/banks-got-big-in-commodities-in-financial -crisis-2013-8. Arroyo reportedly bought seventeen power projects, with a total of 1,217 gross MW, from Delta Power Company LLC in January 2007. Arroyo Energy Completes Buy of Delta Power Co., REUTERS, Jan. 25, 2007, available at http://www.reuters.com/article/2007/01/25/utilities-arroyo-bearstearns-idUS N2519863620070125. In September 2010, Arroyo acquired a $100 \%$ stake in Triton combined cycle facility in Michigan, operated by KMI. Arroyo Energy to Acquire 100\% Stake in Triton Combined Cycle Facility from CIT Group, RESEARCHVIEWS (Sept. 1, 2010), http://www.researchviews.com/energy/power/ DealReport.aspx?sector $=$ Power\&DealID $=145576$.

315. See David Sheppard, JPMorgan's Chief Oil Analyst Leaves Firm, REUTERS, May 31, 2012, available at http://www.reuters.com/article/2012/05/ 31/jpmorgan-eagles-departs-idUSL1E8GVJW020120531.

316. Sambit Mohanty, JPMorgan to Start Physical Oil Trade, Eyes $\$ 200$ Oil, REUTERS, May 15, 2008, available at http://www.reuters.com/article/2008/ 05/14/us-jpmorgan-commodities-idUSSP14850120080514.

317. See id.

318. See Press Release, European Comm'n, State Aid: Comm'n Approves Impaired Asset Relief Measure and Restructuring Plan of Royal Bank of Scotland (Dec. 14, 2009), available at http://europa.eu/rapid/press-release_IP-13 
including its fifty-one percent stake in RBS Sempra, a large U.S. commodities and energy trading company. ${ }^{319}$ In July 2010 , JPMC bought RBS Sempra's global oil, global metals, and European power and gas businesses. ${ }^{320}$ In addition to bringing in approximately $\$ 1.7$ billion of net assets, the $\$ 1.6$ billion acquisition nearly doubled the number of clients JPMC's commodities business could serve and enabled the firm "to offer clients more products in more regions of the world."

In November 2010, JPMC also bought RBS Sempra's North American power and gas business, which added further strength to the operations the firm inherited from Bear Stearns. ${ }^{322}$ This purchase propelled JPMC into the top tier of natural gas and power marketers in North America. ${ }^{323}$ Several months after closing the deal, the firm boasted having control of "a diverse network of physical assets, including 70 billion cubic feet per day of storage capacity-an increase of almost $100 \%$ since the purchase-and almost double the transport capacity it had previously."

By late 2010, JPMC had emerged as a formidable contender for the title of dominant Wall Street energy and commodities

\section{-788_en.htm.}

319. RBS Sempra was a joint venture between RBS and Sempra Energy. See Aldrick, supra note 197 . RBS paid $\$ 1.35$ billion for its $51 \%$ stake in the company. See Sharlene Goff \& Javier Blas, Suitors Line Up for RBS's Sempra Stake, FIN. TIMES, Dec. 9, 2009, http://www.ft.com/cms/s/0/9d587886-e509 -11de-9a25-00144feab49a.html\#axzz2d2Z8hI3N.

320. J.P. Morgan Chase \& Co., Annual Report (Form 10-K), at 184 (Feb. 28, 2012), available at http://investor.shareholder.com/jpmorganchase/secfiling .cfm?filingID=950123-11-19773 [hereinafter J.P. Morgan Chase \& Co., Form $10-\mathrm{K}]$.

321. Id.; see Press Release, J.P. Morgan, J.P. Morgan Completes Commodities Acquisition from RBS Sempra (July 1, 2010), available at http://www .jpmorgan.com/cm/cs?pagename=JPM_redesign/JPM_Content_C/Generic_ Detail_Page_Template\&cid=1277505237241.

322. See Energy Risk Names J.P. Morgan "Oil \& Products House of the Year," J.P.MORGAN (July 1, 2011), http://www.jpmorgan.com/cm/cs?

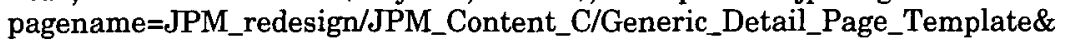

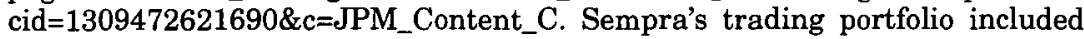
"physical and financial gas and power transactions and access to pipelines and gas storage facilities." Gregory Meyer, JPMorgan Buys RBS Sempra Commodities' Trading Book, FIN. TIMES, Oct. 7, 2010, http://www.ft.com/intl/cms/s/0/ ed83952e-d24e-11df-8fbe-00144feabdc0.html\#axzz2d2Z8hI3N. Nearly 750 counterparties to these trades included "gas producers, power plants, utilities and governments." Id.

323. See id. ("In the second quarter [of 2010], RBS Sempra ranked the fifthlargest North American gas marketer by volume, after BP, Royal Dutch Shell, Conoco-Phillips and Macquarie, according to Platts. JPMorgan was 12th.").

324. J.P. MORGAN, supra note 322. 
trading house, previously shared by Morgan Stanley and Goldman. ${ }^{325}$ The firm conducts most of its physical energy and commodity activities through a wholly-owned subsidiary, J.P. Morgan Ventures Energy Corporation. ${ }^{326}$ JPMC's official website describes the firm as one of the leading energy marketmakers in the world:

We are active in both the physical and financial markets worldwide for crude oil and oil-refined products, coal, power and gas, and have extensive capabilities in the voluntary and mandatory emissions markets.

... Our geographically diverse physical asset portfolio includes more than 40 North American locations. In addition, we are one of the largest natural gas traders in the U.K. and European markets, with daily volumes of approximately 100 million therms. ${ }^{327}$

In addition to oil, gas, and electric power assets, JPMC's crisisdriven acquisitions allowed the firm to become a significant force in global markets for metals. In late 2011, JPMC bought a stake in LME from the bankrupt futures firm, MF Global, and became the exchange's largest shareholder. ${ }^{328}$ As part of its Sempra deal, JPMC acquired control of Henry Bath, a UKbased metals warehousing company that owns and operates one of the largest LME-approved global metal storage networks. ${ }^{329}$ According to the company's own description:

Today, Henry Bath, a subsidiary of JP Morgan, engages in the storage and shipping of exchange traded metals and soft commodities. It offers warehousing, shipping transportation and customs clearance services. The company stores and issues exchange traded warrants for commodities, including aluminium, copper zinc, lead, nickel, tin,

325. See CNBC, supra note 229.

326. J.P. Morgan Chase \& Co., Form 10-K, supra note 320, at 329-30; J.P. Morgan Ventures Energy Corporation: Private Company InformationBusinessweek, BUSINESSWEEK, http://investing.businessweek.com/research/ stocks/private/snapshot.asp?privcapid=28404895 (last visited Oct. 9, 2013).

327. Energy Commodities Trading, J.P.MORGAN, http://www.jpmorgan .com/pages/jpmorgan/investbk/solutions/commodities/energy (last visited Oct. $9,2013)$.

328. Mark Scott \& Michael J. de la Merced, JPMorgan Said to Buy MF Global Stake in London Metal Exchange, N.Y. TIMES, Nov. 23, 2011, http:// dealbook.nytimes.com/2011/11/23/jpmorgan-said-to-buy-mf-global-stake-in -london-metal-exchange/?_r=1.

329. See Mike Jackson, Henry Bath \& Son: A Company and Family History, HENRY BATH, http://www.henrybath.com/assets/_files/documents/jun_11/ HENRYBATH_1308588481_Complete_Henry_Bath_History.pdf (last updated June, 2011) (discussing how, because Henry Bath has extended its storage space in America, it is "recognized as one of the dominant warehouses for the London Metal Exchange"); Desai et al., supra note 299. Curiously, Henry Bath was at one time owned by Enron. Id. 
steel billets, cocoa, coffee and plastics. ${ }^{330}$

Recent media reports indicate that JPMC has been building up its metals warehousing business in order to strengthen the competitive position of Henry Bath vis-à-vis Glencore's Pacorini and Goldman's Metro. ${ }^{331}$ The reports of JPMC moving large amounts of metal from other warehouses into its own suggest that the firm may be rebuilding its stocks and consolidating its warehousing business in key European locations. ${ }^{332}$ This is likely to exacerbate the conflict within the aluminum industry over the unprecedented degree of power that the largest warehousing companies like Henry Bath and Metro exercise over global aluminum prices. ${ }^{333}$

JPMC may be in a particularly sensitive situation because of its controversial move to market the first exchange-traded fund (ETF) backed by physical copper. ${ }^{334}$ JPMC has been reportedly buying up copper since 2010, in anticipation of its ETF launch. ${ }^{335}$ The firm's ability to remove from the market and store in its own warehouses vast quantities of this critically important metal potentially lends more credibility to the fears of market cornering expressed by the opponents of JPMC's ETF plan. ${ }^{336}$ It makes it difficult for JPMC to maintain that trading copper-backed ETF shares is not going to result in artificial in-

330. Jackson, supra note 329.

331. See, e.g., Josephine Mason \& Susan Thomas, Exclusive: JP Morgan Adds Muscle to Metals Warehousing Money, REUTERS, Feb. 1, 2012, available at http://www.reuters.com/article/2012/02/01/us-metals-jpmorgan-idUSTRE81 019J20120201.

332. See id.

333. See id.; see also supra notes 290-309 and accompanying text.

334. See Jack Farchy, Copper ETF Plan Would "Wreak Havoc," FIN. TIMES, May 23, 2012, http://www.ft.com/intl/cms/s/0/a7d32d4c-a4fb-11e1-b421-00144 feabdc0.html\#axzz2d2ZhI3N. The SEC approved JPMC's plan to market its copper-backed ETF in December 2012. See Self-Regulatory Organizations, Exchange Act Release No. 34-68440, 2012 WL 656113 (Dec. 14, 2012), available at http://www.sec.gov/rules/sro/nysearca/2012/34-68440.pdf.

335. See Louise Armitstead \& Rowena Mason, JP Morgan Revealed as Mystery Trader That Bought £1bn-Worth of Copper on LME, TELEGRAPH, Dec. 4, 2010, http://www.telegraph.co.uk/finance/newsbysector/industry/8180304/JP -Morgan-revealed-as-mystery-trader-that-bought-1bn-worth-of-copper-on-LME .html. In April 2012, JPMC reportedly held thirty to forty percent of total copper positions on the LME. CESCO WEEK: Glencore, JP Morgan Hold Dominant Copper Position as Back Flares-Sources, METALBULLETIN (Apr. 18, 2012, 1:34 PM), http://www.metalbulletin.com/Article/3013578/CESCO -WEEK-Glencore-JP-Morgan-hold-dominant-copper-positions-as-back-flares -sources.html.

336. See Armitstead \& Mason, supra note 335; see also Mason \& Thomas, supra note 331 . 
flation of global copper prices. ${ }^{337}$

JPMC's newly acquired physical commodity and energy assets and operations, however, raise a more fundamental legal question as to whether the firm has the statutory authority to own such assets and to conduct such operations in the first place. The Board's original order authorizing JPMC's physical commodity trading did not allow JPMC to own or operate any assets involved in generating, storing, transporting, or processing commodities. ${ }^{338}$ In fact, even energy tolling and energy management were outside of the scope of that original authorization. ${ }^{339}$ As part of its Sempra acquisition, JPMC obtained the Board's approval to continue energy tolling, energy managèment, and long-term wholesale electricity supply activities of RBS ${ }^{340}$ Under the terms of the order, JPMC's newly expanded activities are subject to the requirements and conditions contained in the original RBS Order. ${ }^{341}$

It appears that JPMC generally conducts its physical commodity operations subject to Board-imposed limitations. According to the firm's SEC filings, it entered into operating leases for "premises and equipment" used partially for "energyrelated tolling service agreements." ${ }^{342}$ JPMC also enters into various forms of "supply and off-take" contracts with producers and processors of commodities, such as oil refineries. ${ }^{343}$ These contracts are functionally similar to energy management arrangements JPMC and other FHCs have with electric power plants under the "complementary" authority grants. ${ }^{344}$ Thus, in April 2012, business media reported that Delta Airlines was

337. See Jack Farchy, JPMorgan Flip Flops on Commodity ETFs, FIN. TIMES, Sept. 6, 2012, http://www.ft.com/intl/cms/s/0/a782c1c6-f772-11e1-ba54 -00144feabdc0.html\#axzz2d2Z8hI3N.

338. See supra notes $185-95$ and accompanying text.

339. See supra notes $185-95$ and accompanying text.

340. See Letter from Board to JPMorgan Chase \& Co. (June 30, 2010) [hereinafter JPMC Board Order].

341. See id.; see also RBS Order, supra note 196.

342. J.P. Morgan Chase \& Co., Form 10-K, supra note 320 , at 289. This probably reflects the general practice among FHCs engaged in physical commodity trading under the Board's "complementary" orders. See supra Part II.B.1. To avoid legally owning or operating any physical assets involved in the marketing chain, JPMC probably enters into some form of a sale-and-leaseback contract, whereby an unaffiliated third party is the legal owner of the physical facilities and operates those facilities under a lease agreement with JPMC.

343. See Meyer, supra note 6.

344. See supra Part III.A.1. 
planning to purchase Conoco's idle Trainer oil refinery, in order to lower its jet fuel costs, and that JPMC agreed to finance the entire production process through a supply and off-take agreement. ${ }^{345}$ Under the arrangement, JPMC would purchase and pay for delivery of the crude for the refinery's operation, sell the jet fuel to Delta at a wholesale price, and then sell other refined products on the open market. ${ }^{346}$ In July 2012 , JPMC entered into a similar supply and off-take arrangement with the largest oil refinery on the East Coast, owned and operated by Sunoco and Carlyle. ${ }^{347}$ These transactions significantly reduce refineries' working capital needs and offload the risk on JPMC, which has far greater balance-sheet capacity. ${ }^{348}$ In effect, JPMC contractually replicates owning oil refineries without violating the letter of the law.

Nevertheless, there are signs that the Board may feel somewhat uneasy about at least some of JPMC's recently acquired physical commodity operations. The 2010 JPMC Board Order explicitly required JPMC to either divest or conform to the requirements of the BHCA the activities of (1) "owning, investing in, or operating" commodity storage facilities, and (2) making and taking physical delivery of metal concentrates and other commodities not previously approved by the Board for trading. ${ }^{349}$ The Board gave JPMC a time limit of two years after the acquisition to comply with these commitments but reserved a discretionary right to extend that grace period. ${ }^{350}$ In addition,

345. See, e.g., Kate Kelly, The Glue in Delta's Possible Refinery Deal: JP Morgan, CNBC (Apr. 11, 2012, 12:48 PM), http://www.cnbc.com/id47017435.

346. See id.

347. See Janet McGurty, Carlyle Saves Big Sunoco Refinery with Shale Boom, JPMorgan, REUTERS, July 2, 2012, available at http://www.reuters .com/article/2012/07/02/sunoco-carlyle-philadelphia-idUSL2E8I20OS20120702; see also Sheppard \& Alper, supra note 1.

348. See Meyer, supra note 6. According to Blythe Masters, the head of JPMC's global commodities unit, it is this "risk and balance sheet capacity" that puts big banks in the unique position to do these supply and off-take deals. See id. (internal quotation marks omitted). Non-bank commodity trading houses typically use about seventy-five to eighty percent of their credit lines, which leaves them little room for taking on new deals, while still maintaining a comfortable cushion against sudden price rises. Id.

349. See JPMC Board Order, supra note 340. Because metal concentrate futures were not traded on major organized commodity exchanges, the Board excluded metal concentrates from the scope of its original order approving RBS's "complementary" activities. See RBS Order, supra note 196, at C67.

350. JPMC Board Order, supra note 340 . Under the terms of the original RBS Order, RBS committed to discontinue within two years its activities of owning or investing in storage facilities for commodities that RBS was not 
the Board prohibited JPMC from expanding the scope of these activities beyond those Sempra conducted immediately prior to its acquisition by JPMC. ${ }^{351}$

In April 2012, JPMC sold its metals-concentrate trading unit to Connecticut-based Freepoint. ${ }^{352}$ The firm's continuing ownership and operation of Henry Bath, however, presents a potential problem in this regard. As of this writing, JPMC has not yet ceased its lucrative metal warehousing operations, even though they may be inconsistent with the terms of the Board's "complementary" orders. ${ }^{354}$

JPMC's speedy rise to the top of the Wall Street commodity trading circle has created new legal and reputational risks for the firm. In the summer of 2012, the FERC launched an investigation into JPMC's electric power trading practices. ${ }^{355}$ The agency began its probe in response to complaints from electric power grid operators in California and the Midwest in 2011, alleging that JPMC's power traders had intentionally bid up wholesale electricity prices by more than $\$ 73$ million. ${ }^{356}$ Artificial inflation of wholesale prices benefits power generators (which is functionally JPMC's role) but translates into higher power prices for households and other end-users. ${ }^{357}$ Moreover,

permitted to own or hold under the BHCA, as well as not to make or take physical delivery of metal concentrates. See RBS Order, supra note 196, at C67. Here, the Board restarted the clock for JPMC, giving it at least until mid2012 to comply with these requirements.

351. See JPMC Board Order, supra note 340 .

352. Josephine Mason, Freepoint Agrees to Buy JPM's Metal Concentrates Business, REUTERS, Apr. 25, 2012, available at http://www.reuters.com/article/ 2012/04/25/freepoint-jpm-concentrates-idUSL2E8FP0T320120425; Josephine Mason, JPMorgan Poised to Sell U.S. Metal Concentrate Unit, REUTERS, Apr. 20, 2012, available at http://www.reuters.com/article/2012/04/20/us-jpmorgan -concentrates-idUSBRE83J1KS20120420. The sold unit excluded JPMC's physical copper and aluminum trading desks in London and Singapore. Josephine Mason, JPMorgan Poised to Sell U.S. Metal Concentrate Unit, REUTERS, Apr. 20, 2012, available at http://www.reuters.com/article/2012/04/20/us -jpmorgan-concentrates-idUSBRE83J1KS20120420.

354. It is, of course, possible that the Board quietly exercised its discretion to extend the two-year grace period, as provided in the JPMC Board Order, supra note 340 .

355. See Scott DiSavino \& David Sheppard, JPMorgan Probed over Possible Power Market Manipulation, REU'TERS, July 3, 2012, available at http://www .reuters.com/article/2012/07/03/us-utilities-jpmorgan-ferc-idUSBRE8620LK20 120703.

356. Id.

357. See id. This scenario brings back memories of the infamous California power market manipulation scandal and the Enron failure in 2001. See generally Tapes: Enron Plotted to Shut Down Power Plant, CNN.COM (Feb. 3, 2005, 
as recent FERC enforcement actions demonstrate, the focus of today's fraud prevention in power markets is on more subtle trading strategies that seek to manipulate the price of physical power in order to increase the value of the manipulator's financial bets. ${ }^{358}$ JPMC's role as the leading global energy derivatives dealer ${ }^{359}$ potentially exacerbates concern over the firm's traders engaging in this type of market manipulation. ${ }^{360}$

Even in the absence of an admission of wrongdoing on the part of JPMC, the very fact of FERC's investigation and sanctions $^{361}$ raises uncomfortable questions about the potential impact of the firm's newly-expanded energy operations on its overall institutional culture and reputation. These concerns become particularly acute in the context of the infamous "London Whale" scandal that exposed deep problems with JPMC's risk management practices. ${ }^{362}$ Both cases demonstrate the inherent difficulty of drawing regulatory distinctions among various transactions based on the firm's intentions and proclaimed business purposes. Just as a legitimate hedge can become a lucrative bet under favorable market conditions, so can financingand-risk-management arrangements with oil refineries and power generators become a profitable proprietary business of energy merchanting. ${ }^{363}$ How the law should deal with this complex reality is one of the key questions in today's financial ser-

11:58 PM), http://www.cnn.com/2005/US/02/03/enron.tapes (discussing the Enron California power scandal).

358. See, e.g., DiSavino \& Sheppard, supra note 355.

359. See supra note 325 and accompanying text.

360. On September 20, 2012, FERC initiated an official proceeding accusing J.P. Morgan Ventures Energy Corporation, JPMC's commodity trading arm, of intentionally providing misleading information to the regulator. News Release, Fed. Energy Regulatory Comm'n, FERC Initiates Proceeding into Actions by JP Morgan (Sept. 20, 2012), http://www.ferc.gov/media/news-releases/ 2012/2012-3/09-20-12-E-24.asp.

361. JPMC ultimately settled this matter by agreeing to pay the FERC $\$ 410$ million in civil penalties, including $\$ 125$ million in disgorgement of unjust profits, without admitting any wrongdoing. News Release, Fed. Energy Regulatory Comm'n, FERC, JP Morgan Unit Agree to $\$ 410$ Million in Penalties, Disgorgement to Ratepayers (July 20,2013 ), available at http://www.ferc .gov/media/news-releases/2013/2013-3/07-30-13.asp\#.Ui1mRRZEO5d; see also Brian Wingfield \& Dawn Kopecki, JPMorgan to Pay $\$ 410$ Million in U.S. FERC Settlement, BLOOMBERGLAW (July 30, 2013, 10:33 AM), http://about .bloomberglaw.com/legal-news/jpmorgan-to-pay-410-million-in-u-s-ferc -settlement.

362. See generally Jessica Silver-Greenberg \& Suzanne Craig, JPMorgan Trading Loss May Reach $\$ 9$ Billion, N.Y. TIMES, June 28, 2012, http:// dealbook.nytimes.com/2012/06/28/jpmorgan-trading-loss-may-reach-9-billion.

363. See supra notes $314-27$ and accompanying text. 
vices regulation reform.

\section{WHAT SAY WE? LEGAL, POLICY, AND THEORETICAL IMPLICATIONS}

As the preceding discussion demonstrates, the recent financial crisis has fundamentally altered the nature and scope of large U.S. banking organizations' involvement in physical commodity and energy markets. This Part addresses legal, policy, and theoretical implications of this phenomenon.

This Part argues, first, that the BHCA does not provide a clear and effective legal framework for making a fundamental policy decision on the socially efficient degree of mixing banking and commercial commodities activities. It argues, further, that there are important policy reasons why such mixing, at least to the degree to which it is done today, may be socially undesirable and inefficient. In addition to the traditional concerns underlying the original doctrine of separation of banking and commerce, it may be especially critical to keep banks out of the strategically important and complex markets for energy and physical commodities for reasons of systemic risk prevention, regulatory efficiency, and the long-term governability of financial institutions.

Finally, this Part argues that taking these policy concerns seriously potentially necessitates extending the prohibition on physical commodity and energy trading beyond banks and BHCs to all SIFIs. In that sense, the recent transformation of large U.S. financial institutions into global commodity dealers raises not only urgent legal and policy issues but also fundamental theoretical questions about the nature, social functions, and proper regulatory boundaries of modern financial intermediation. This Part concludes by outlining some of these theoretical issues for future research.

\section{A. Post-Crisis Legal Paradoxes: New Game Under Old RULES, OR OLD GAME UNDER NEW RULES?}

Even a cursory overview of publicly available information shows that the current commodity operations of Morgan Stanley, Goldman, and JPMC defy carefully drawn pre-crisis regulatory boundaries of FHC-permissible physical commodities activities-and effectively nullify the principle of separating banking from commerce. Broadly, there are two potential ways to resolve this tension: either FHCs' impermissible commercial activities must be brought into compliance with the law, or the 
law should be changed to reflect FHCs' newly acceptable role as global commodity merchants.

\section{The BHCA Solution: Definitely, Maybe}

The BHCA does not provide a definitive framework for making this fundamental choice. In fact, the statute is surprisingly vague on this issue.

The commodity grandfathering provision of section $4(0)$ of the BHCA potentially provides the greatest latitude for Morgan Stanley and Goldman, as two FHCs qualifying for this exemption, to continue owning and operating their extensive commodity assets "and underlying physical properties." firms have publicly stated their intent to rely on this exemption to keep their physical commodity operations even after becoming subject to the BHCA activity restrictions. ${ }^{365}$ On its face, section 4(o) does not impose any qualitative limits on grandfathered activities: the language of the provision is broad and open to expansive interpretation. ${ }^{366}$ Yet, as discussed above, the legislative history of this grandfathering provision, originally conceived as a special concession to "woofies"-financial institutions without access to FDIC-insured retail deposit-takingindicates that it was not designed to operate as a completely open-ended commodity-business license for banking organizations. ${ }^{367}$ It is doubtful that, at the time the GLBA was passed, Congress actually envisioned the current extent and depth of these firms' physical commodities operations. ${ }^{368}$ Ironically, the very breadth of the grandfathering exemption in section 4(o) of

364. 12 U.S.C. $\$ 1843(0)$ (2012).

365. Thus, Morgan Stanley provided this disclosure in its SEC filings: We are engaged in discussions with the Federal Reserve regarding our commodities activities, as the BHC Act provides a grandfather exemption for "activities related to the trading, sale or investment in commodities and underlying physical properties," provided that we were engaged in "any of such activities as of September 30,1997 in the United States" and provided that certain other conditions that are within our reasonable control are satisfied.

Morgan Stanley, Form 10-K, supra note 135, at 27. Goldman's SEC filings also expressed the firm's confidence that it qualified for the section 4(o) exemption when it stated "we are permitted under the GLB Act to continue to engage in certain commodities activities in the United States that may otherwise be impermissible for bank holding companies, so long as the assets held pursuant to these activities do not equal five percent or more of our consolidated assets."

Goldman Sachs Grp., Form 10-K, supra note 134, at 9.

366. See supra notes 115-21 and accompanying text.

367. See discussion supra Part I.B.3.

368. See supra notes $122-30$ and accompanying text. 
the BHCA may actually render it less useful to Morgan Stanley and Goldman in practice, as the Board may be more reluctant to ratify such an open-ended expansion of FHCs' commercial commodities activities. ${ }^{369}$

An even greater irony is that the commodity grandfathering provision was included in the GLBA as an inducement for investment banks to become regulated FHCs. ${ }^{370}$ Yet, during the 2008 crisis, no additional incentives were necessary to induce every surviving investment bank to seek BHC status. ${ }^{371}$ In the wake of the crisis that changed the face of the industry, there seems to be no plausible policy basis for this ambiguous and remarkably broad commodity grandfathering provision.

In the alternative, Morgan Stanley, Goldman, and JPMC can seek the Board's approval of their existing commodities activities as complementary to FHC-permissible financial activities, such as commodity derivatives. As discussed above, the BHCA does not define what "complementary" means and leaves it largely to the Board's discretion to determine whether any particular activity fits that description. ${ }^{372}$ An examination of published Board orders shows the regulator's general reluctance to allow FHCs to incur non-financial risks associated with owning and operating oil rigs, coal mines, refineries, storage tanks, pipelines, and tankers. ${ }^{373}$ As is the case with any agency policy, however, the Board's position may change in response to various internal and external factors. Moreover, even if the Board insists on its pre-crisis determination that "complementary" commodity trading activities exclude direct ownership and operation of physical assets, the practical impact of

369. Curiously, TransMontaigne Partners, an indirect oil transportation and terminaling subsidiary of Morgan Stanley, disclosed in its SEC filings that in October 2011 Morgan Stanley imposed a temporary moratorium on the company's "significant" asset acquisitions and investments, as a necessary measure in light of the uncertain regulatory environment relating, in part, to Morgan Stanley's non-financial investments. See TransMontaigne Partners, Form 10-K, supra note 263, at 34-35. This decision by Morgan Stanley may have indicated the firm's doubts regarding the availability of the grandfathering exemption for its oil and gas operations. According to recent media reports, at least some Board officials are increasingly skeptical about Morgan Stanley's ownership of TransMontaigne. See, e.g., Aaron Lucchetti \& Liam Pleven, Wall Street Is Rethinking Commodity-Trading Role, WALL ST. J., Oct. 23, 2012, at C1.

370. See supra notes $122-30$ and accompanying text.

371. See, e.g., supra note 228 and accompanying text.

372. See supra Part I.B.2.

373. See, e.g., supra text accompanying note 187. 
that seemingly bright-line border may be rather limited. FHCs can (and do) use various forms of "sale and lease-back" or "supply and off-take" arrangements to replicate the effects of owning and operating individual key links in the commodity supply chain. ${ }^{374}$

Finally, FHCs can use merchant banking authority to keep, and even expand, their current physical commodity assets. ${ }^{376}$ Merchant banking is a potentially tempting choice because it can be used without the Board's pre-approval: the FHC can make the determination that it holds certain investments under that statutory authority. ${ }^{376}$ As discussed above, FHCpermissible merchant banking investments must meet certain statutory requirements intended to prevent FHCs from actively running the commercial businesses of their portfolio companies. ${ }^{377}$ The holding period limitations ${ }^{378}$ and the prohibition on FHCs' involvement in "routinely managing" portfolio companies' businesses ${ }^{379}$ seem tough in principle but are not necessarily a "deal-breaker." ${ }^{380}$ Large FHCs already invest in commodity and energy companies under the merchant banking authority. ${ }^{381}$ It is not difficult to structure specific investments to meet the formal statutory criteria without giving up real control. It is difficult to ascertain, however, whether these investments are, in fact, truly passive private equity interests acquired purely for the purposes of profitable resale. In practice, FHCs can-and most likely do-exercise informal influence on portfolio companies' business decisions, which may be just as effective as a formal management role. ${ }^{382}$

374. See supra Part I.B.2; supra note 342; see also supra notes 343-48 and accompanying text. While these arrangements may potentially reduce direct risks to individual FHCs' safety and soundness, their proliferation implicates other policy concerns the Board must consider in granting "complementary" powers to FHCs: excessive concentration of market power, conflicts of interest, and increased systemic risk. See supra note 105 and accompanying text; infra Part IV.B.

375. See 12 U.S.C. $\S 1843(k)(4)(H)(2012)$.

376. See id.

377. See supra Part I.B.1.

378. See supra notes $86-89$ and accompanying text.

379. See supra notes $90-95$ and accompanying text.

380. See supra note 96 and accompanying text.

381. See supra notes 280-83 and accompanying text. Thus, Goldman reportedly structured its investment in Metro as a merchant banking investment. See Sheppard et al., supra note 25.

382. Goldman's investment in KMI provides a good example. On its face, it appears to be a bona fide merchant banking investment. Yet, even if Goldman itself cannot formally participate in routinely managing KMI's affairs, its long- 
Moreover, as discussed below, using merchant banking authority to invest in companies engaged in producing, transporting, and marketing physical commodities may become an increasingly attractive option for FHCs in the context of the regulatory reform mandated by the Dodd-Frank Wall Street Reform and Consumer Protection Act of 2010 (the Dodd-Frank Act). ${ }^{383}$

time co-investors and private equity deal partners, Carlyle and Riverstone, are free to so participate. See supra notes 280-83 and accompanying text. It is not difficult to imagine a situation in which Goldman's non-FHC partners direct KMI's business in a manner consistent with Goldman's business goals and commodity trading strategy. Informal influence of this sort is difficult to detect and prevent. KMI is engaged principally in the same lines of business as Morgan Stanley's TransMontaigne subsidiaries that play a crucial role in Morgan Stanley's commodity-trading operations. See id.; supra notes $261-65$ and accompanying text. If Goldman were to similarly use its stake in KMI to secure access to KMI's transportation and storage facilities in order to facilitate Goldman Sachs's commodity trading, its investment in KMI would not properly qualify for the merchant banking exemption. Yet, Goldman may be following the same pattern with respect to any portfolio company. Without more information, this is merely a plausible hypothesis. It shows, however, the importance of subjecting FHCs' merchant banking investments in commodity and energy assets to closer scrutiny for compliance with the spirit, as well as the letter, of the law.

383. See infra notes 398-99 and accompanying text.

It should be noted here that Goldman and Morgan Stanley potentially have another option for keeping all of their existing commodities assets and activities outside the prohibitions of section 4 of the BHCA. In theory, both of these firms can surrender the bank charters of their deposit-taking subsidiaries and re-charter them as industrial banks or other institutions exempt from the BHCA definition of a "bank." See 12 U.S.C. $\S 1841$ (c) (2012). As a result of this "de-banking," Goldman and Morgan Stanley would lose their official BHC status. Nevertheless, they will remain subject to extensive regulation and supervision by the Board as non-bank SIFIs. Dodd-Frank Wall Street Reform and Consumer Protection Act, Pub. L. No. 111-203, § 113, 124 Stat. 1376, 1398-1402 (2010) (codified at 12 U.S.C. \$ 5323) (authorizing the newly created Financial Stability Oversight Council (FSOC) to designate systemically important non-bank financial companies to be supervised by the Board under heightened prudential standards) [hereinafter Dodd-Frank Act]; Dodd-Frank Act $\$ 117,124$ Stat. at 1403-06 (codified at 12 U.S.C. \$ 5324-25) (mandating that a systemically important BHC will remain subject to the Board's supervision and heightened prudential standards even if it ceases to own or control a U.S. bank).

Surrendering their subsidiaries' bank charters, therefore, is not likely to make a significant difference in the overall regulatory burden on Goldman and Morgan Stanley. Dodd-Frank Act $\S 115,124$ Stat. at 1406-08 (codified at 12 U.S.C. \& 5326) (mandating enhanced prudential regulation of non-bank SIFIs). Even though, as a technical matter, they will be free to conduct commercial activities without regard to the BHCA's prohibitions, the Board and FSOC will retain broad authority to monitor and regulate their activities in a manner very similar to the regulation of BHCs. See id. It is not clear how the regulators will exercise this authority in practice. Yet, if the regulators are 
2. The Discreet Charm of the Dodd-Frank Act

The Dodd-Frank Act, the most wide-ranging financial sector reform law since the Great Depression, mandates a wide range of measures aimed at detecting and reducing systemic risk. $^{384}$ The practical efficacy of the Dodd-Frank Act, however, depends on the final outcomes of the long and complicated implementation process. As of this writing, there is still much uncertainty as to its ultimate impact on financial intermediaries' business practices.

Although the Dodd-Frank Act reiterated Congress's general commitment to the principle of separation of banking and commerce ${ }^{385}$ the new law does not directly address the issue of the proper scope of FHC-permissible non-financial activities. It is not clear whether and how the regulatory implementation of the Act will ultimately affect large FHCs' physical commodities operations. As Goldman, Morgan Stanley, and JPMC adapt their business models to the evolving regulatory regime, their individual choices are difficult to predict with any certainty.

The potential effect of the Volcker Rule on FHCs' commodities trading, both in financial and physical markets, seems to be an area of particular concern in this respect. The Volcker Rule generally prohibits "banking entities" from proprietary trading in financial instruments and from investing in private equity and hedge funds. ${ }^{386}$ There is a great deal of uncertainty as to whether the implementation of that rule would force FHCs to reduce or even cease their proprietary trading activities in physical commodities. Although the statutory language is vague and lacking in detail, it outlaws only short-term proprietary trading in financial instruments and not physical commodities. ${ }^{387}$

genuinely inclined to stop Goldman and Morgan Stanley from growing their commodity-trading businesses, they should not encounter much difficulty in using their statutory powers over non-bank SIFIs to achieve that goal. Thus, as a practical matter, "de-banking" does not seem to be a viable exit option for Goldman and Morgan Stanley, especially given the inescapably bad "optics" of such a move.

384. See Dodd-Frank Act, 124 Stat. 1376-2223 (2010) (codified in scattered sections of 12,15 U.S.C.).

385. Dodd-Frank Act $\S 603(b)(1), 124$ Stat. at 1598-99 (codified at 12 U.S.C. § 1815).

386. Dodd-Frank Act $\S 619(\mathrm{~h})(1), 124$ Stat. at 1629 (codified at 12 U.S.C. $\S 1851$ ) (defining "banking entities" as all federally-insured deposit-taking institutions and their affiliates).

387. Dodd-Frank Act $\S 619(\mathrm{~h})(4), 124$ Stat. at 1630 (codified at 12 U.S.C. $\S 1851$ ). The statute defines "proprietary trading" as follows: 
It is not clear, however, whether commodity forwards, or contracts for future delivery of physical commodities, are properly classified as cash trades or financial instruments. In October 2011, federal bank regulators published a proposed rule that treated commodity forwards as financial contracts. ${ }^{388}$ The purpose for this inclusion was to prevent large FHCs from evading the Volcker Rule by shifting their proprietary trading from derivatives to physical markets. ${ }^{389}$ In response, large FHCs began lobbying for an explicit exemption of commodity forwards from the scope of the Volcker Rule. ${ }^{390}$ JPMC and Morgan Stanley submitted comments on the proposed rulemaking, arguing that the Volcker Rule prohibitions threatened their ability to engage in physical commodity trading. ${ }^{391}$ Morgan Stanley's comment letter contained a particularly elaborate and extensive argument that prohibitions on proprietary trading in commodity derivatives would significantly limit the firm's ability to conduct physical commodity operations, and that restrictions on the firm's physical commodities activities would greatly harm its customers. ${ }^{392}$ The letter used a jet fuel supply agreement with an airline as an example of its "customerfacing" "market-making" transactions in commodities markets that would be rendered impracticable or possibly illegal under the agencies' proposed rules. ${ }^{393}$

The veracity of these claims must be assessed in the context of Morgan Stanley's strategic efforts to minimize the scope of the Volcker Rule restrictions on its ability to trade and deal in financial instruments. As finally implemented, the Volcker

The term 'proprietary trading' . . . means engaging as a principal for the trading account of the banking entity ... in any transaction to purchase or sell, or otherwise acquire or dispose of, any security, any derivative, any contract of sale of a commodity for future delivery, any option on any such security, derivative, or contract, or any other security or financial instrument that the appropriate Federal banking agencies, the Securities and Exchange Commission, and the CommodId. ity Futures Trading Commission may, by rule ... determine.

388. 76 Fed. Reg. 68,845 (Nov. 7, 2001).

389. See Sheppard \& Alper, supra note 1 (quoting Senator Carl Levin).

390. See Sheppard \& Alper, supra note 1.

391. See Letter from Barry L. Zubrow, Exec. Vice President, JPMorgan Chase \& Co., to Dep't of the Treasury, Office of Domestic Fin. et al. (Feb. 13, 2012), at 28-29; Letter from Simon T.W. Greenshields, Global Co-Head of Commodities, Morgan Stanley, to Fed. Reserve Sys. et al. (Feb. 13, 2012), [hereinafter MS Commodities Comment].

392. MS Commodities Comment, supra note 391.

393. Id. at 8. 
Rule may, in fact, make FHCs' physical commodity trading operations more burdensome or less lucrative. Thus, in July 2012, the media reported that Morgan Stanley was contemplating a sale of a minority stake in its commodities unit, allegedly as a preemptive move to comply with the Volcker Rule. ${ }^{394}$ These reports suggested that Morgan Stanley was seeking a non-bank partner to take over the parts of the commodity trading business potentially affected by the Volcker Rule's prohibitions on proprietary trading. ${ }^{395}$ According to Morgan Stanley's former treasurer, however, it is likely that Morgan Stanley is simply looking to recapitalize its commodities unit with outside equity in order to raise its credit rating after Moody's Investors Service (Moody's) downgraded the firm's credit in June $2012 .{ }^{396}$

In this connection, it is important not to underestimate financial institutions' proven ability to engage in successful regulatory arbitrage to avoid constraints on their profit-making activities. Morgan Stanley's characterization of its commercial fuel logistics business as a "market-making" function, essentially indistinguishable from other forms of client-driven financial intermediation, may signal one such sophisticated arbitrage strategy. ${ }^{397}$ Large FHCs may also shift more of their physical

394. See, e.g., Christine Harper, Morgan Stanley May Sell CommoditiesUnit Stake to Fund, BLOOMBERG (July 20, 2012), http://www.bloomberg .com/news/2012-07-20/morgan-stanley-may-sell-commodities-unit-stake-to -fund.html (reporting Morgan Stanley's talks with Blackstone Group and Qatar Investment Authority (QIA) as potential purchasers of a minority stake in the firm's commodity business).

395. Id.

396. Id. In October 2012, there were more reports of Morgan Stanley's ongoing negotiations with QIA regarding potential sale of a majority stake in the firm's commodities unit. Tracy Alloway \& Javier Blas, $M$ Stanley in Talks over Commodities Unit, FIN. TIMES, Oct. 4, 2012, http://www.ft.com/intl/cms/s/0/ 0b2ee132-0d76-11e2-bfcb-00144feabdc0.html\#axzz2eEZAEPXd.

397. MS Commodities Comment, supra note 391. Morgan Stanley's comment letter prompted an MIT Professor John E. Parsons to post this comment on his blog:

[M]organ Stanley's jet fuel business provides a real service ... It's just not market making in financial securities. One can imagine that Morgan Stanley's ability to offer jet fuel logistics services on favorable terms benefits from the banks expert analysis of volatile petroleum product prices, and also on its ability to trade in both the physical and financial petroleum and petroleum product markets. But none of that transforms the business into market making. There are plenty of nonbanks that provide exactly this kind of logistics services in all kinds of commodities.

John E. Parsons \& Antonio S. Mello, Morgan Stanley Says Potahto, BETTING THE BUS. (Apr. 23, 2012, 6:13 AM), http://bettingthebusiness.com/2012/04/23/ morgan-stanley-says-potahto. 
commodities assets into their merchant banking divisions. Because the Volcker Rule targets only short-term trading activities for the banking entity's own account, it does not apply to long-term merchant banking investments. ${ }^{398}$ This potentially creates a loophole in the new regulatory regime for FHCs wishing to keep their commodities operations. ${ }^{399}$ It may be particularly difficult to detect and counteract this form of regulatory arbitrage, because the key test for a bona fide merchant banking investment turns ultimately on the FHC's intent-a notoriously elusive factor.

Trading, producing, storing, and moving physical commodities remains a strategically important business for large FHCs like Morgan Stanley, Goldman, and JPMC. According to banks' own statements, trading in physical markets is indispensable to their commodity derivatives operations. ${ }^{400}$ Not only does physical trading give their derivatives traders an invaluable informational advantage but it also puts these firms in the center of the strategically important and profitable markets for physical commodities and energy. ${ }^{401}$ In addition, it offers potential

398. Paul Volcker himself admitted that the rule named after him did not explicitly target potentially unacceptable proprietary risk-taking by FHCs through long-term merchant banking investments. See Tom Braithwaite, Volcker Takes Aim at Long-Term Investments, Fin. TIMES, Jan. 20, 2011, http://www.ft.com/intl/cms/s/0/2a03c58c-242a-11e0-a89a-00144feab49a.html\# axzz2gX8IEQC5.

399. At this point, however, it is not clear whether holding commodity assets under the merchant banking authority would shield FHCs from the undesirable effects of the Volcker Rule. One potential problem under the Volcker Rule is that it restricts FHCs' ability to make merchant banking investments through private equity funds. Dodd-Frank Act, Pub. L. No. 111-203, §619, 124 Stat. 1376, 1620-31 (2010) (codified at 12 U.S.C. § 1850a-1851). Since FHCs typically make their merchant banking investments through funds, alongside client money, this provision of the Volcker Rule may force FHCs to restructure their merchant banking investments. Another potentially serious issue is whether merchant banking portfolio companies-the FHC-controlled entities that would actually conduct physical commodity trading-are themselves subject to the Volcker Rule as "banking entities." See Letter from John F.W. Rogers, Chief of Staff, Goldman Sachs, to Office of the Comptroller of the Currency (Feb. 13, 2012), at 16 (arguing that federal regulators should explicitly exclude merchant banking portfolio companies from the definition of "banking entity" under the Volcker Rule).

400. See Dmitry Zhdannikov, Banks Struggle to Adapt or Survive in Commodities, REUTERS, Nov. 5, 2012, available at http://www.reuters.com/article/ 2012/11/05/us-banks-commodities-idUSBRE8A40QC20121105.

401. Experts predict that global demand for oil, gas, and metals will continue to increase, in order to accommodate the growing needs of China and other developing countries. See Guy Chazan, Renewables Will Widen Investor Enthusiasm, FIN. TIMES, June 1, 2012, http://www.ft.com/intl/cms/s/0/975ae 
regulatory arbitrage opportunities for banking organizations able to shift their risk-taking from the increasingly heavily regulated derivatives into physical trades. It is unlikely, therefore, that these institutions will give it all up without a fight. ${ }^{402}$ The stakes in this fight are high, not only for the financial firms but for the general public as well. Whether systemically important U.S. banking organizations should be allowed to continue their present activities in physical commodity and energy markets-and thus render the principle of separating banking from commerce effectively meaningless-is an important public policy decision that requires careful and informed deliberation.

\section{B. Rethinking THE Foundational MYTH: SHOUld Policy PERMIT BANKS TO BE COMMODITY MERCHANTS?}

An examination of FHCs' role in physical commodity mar-

8dc-a4ca-11e1-9a94-00144feabdc0.html?siteedition=intl\#axzz2eEZAEPXd. Recent decisions by Germany and Japan to shut down their nuclear power facilities and move primarily to natural gas-fired power generation will further increase demand for liquefied natural gas, crude oil, and coal. See Jonathan Soble \& Javier Blas, Japan to Phase Out Nuclear Power, FIN. TIMES, Sept. 14, 2012, http://www.ft.com/intl/cms/s/0/f9961e7c-fe3e-1le1-8228-00144feabdc0 .html.

402. Initial media reports on Morgan Stanley's sale plans noted the firm's strong desire to retain the majority stake in its lucrative commodities business. Harper, supra note 394; Brett Philbin, Morgan Stanley Not Selling Commodities Unit, WALL ST. J., June 6, 2012, http://www.marketwatch.com/ story/morgan-stanley-not-selling-commodities-unit-2012-06-06. Goldman reportedly considered a potential spin-off of its commodities unit but decided against it. See Lucchetti \& Pleven, supra note 369 (quoting the firm's statement that it "never seriously looked at" such a spin-off). Until mid-2013, JPMC also denied having plans to divest its commodities operations. Zhdannikov, supra note 400. In mid-2013, the media again reported on Morgan Stanley's downsizing of commodities-trading personnel, as well as Goldman's informal efforts to "sound out" potential buyers for Metro. Javier Blas, Morgan Stanley Cuts Back Commodities Business, FIN. TIMES, June 20, 2013, http://www.ft.com/intl/cms/s/0/af923c1e-d9b4-11e2-98fa-00144feab7de.html;

Clarke \& Day, supra note 306.

As of this writing, however, it is difficult to ascertain to what extent, or even whether, any of these reported moves signal these institutions' retrenchment, temporary or permanent, from physical commodities. Strictly speaking, divesting ownership of warehousing or pipeline-operating companies does not preclude an FHC from trading physical commodities. Generally, individual firms' decisions to grow or shrink their physical commodity operations are driven by numerous considerations, including prevailing trends in commodity prices, shifts in these firms' revenues and regulatory compliance costs, political pressures, and even personal preferences of their top managers. As a matter of principle, however, particular firms' business decisions do not diminish the importance of developing a thoughtful and coherent policy basis for regulating banking organizations' physical commodity activities. 
kets raises fundamentally important issues not only of current law but also of future doctrine and policy. Chief among them is whether we should reassert the principle of separation of banking and commerce. As discussed above, the main reasons for not mixing banking with general commerce have traditionally included the needs to preserve the safety and soundness of the federally-insured U.S. banking system, to ensure a fair and efficient flow of credit to productive economic enterprise, and to prevent excessive concentration of financial and economic power. Are these stated policy reasons behind the legal principle still compelling today? What do the physical commodities activities of large U.S. FHCs reveal about the ongoing relevance and validity of these policy objectives?

\section{Safety and Soundness; Systemic Risk}

From the perspective of safety and soundness of individual banking organizations, there is at least one straightforward, plausible argument for allowing FHCs to conduct physical commodities trading as a diversification strategy. Diversifying their business activities by investing in oil pipelines and metals warehouses should make FHCs less vulnerable to periodic crises in financial markets. Trading, transporting, storing, and processing physical commodities is a volatile business, and that volatility is expected to continue for the foreseeable future ${ }^{403}$ It is a reliably profitable business, as global commodity prices have been rising since the early 2000 s and, despite sudden ups and downs, are expected to continue rising in response to increasing global demand. ${ }^{404}$ Intermediating physical commodities trading is the surest way to profit from these trends.

As professional intermediaries, financial institutions appear to be perfectly positioned to assume that lucrative role. Large FHCs have huge balance sheets, access to cheaper financing, superior access to information and in-house research capacity, and sophisticated financial derivatives trading capabilities. To the extent that utilizing these unique advantages allows FHCs to be more efficient, low-cost suppliers of physical commodities and related logistics services, allowing them to perform that function should produce economic benefits for the

403. See Tony Levene, Commodity Prices: High-Flying Oil Kings, FIN. TIMES, Sept. 17, 2012, http://www.ft.com/intl/cms/s/2/38330322-f8f7-11e1-8d92 -00144 feabdc0.html\#axzz2eEZAEPXd.

404. Id. 
FHCs and their customers. ${ }^{405}$

This traditional economic efficiency-based argument, however, misses or ignores a crucial fact-namely, that running a physical commodities business also diversifies the sources and spectrum of risk to which FHCs become exposed as a result. Let us imagine, for example, that an accident or explosion on board an oil tanker owned and operated by one of Morgan Stanley's subsidiaries causes a large oil spill in an environmentally fragile area of the ocean. As the shocking news of the disaster spreads, it may lead Morgan Stanley's counterparties in the financial markets to worry about the firm's financial strength and creditworthiness. Because the full extent of Morgan Stanley's clean-up costs and legal liabilities would be difficult to estimate upfront, it would be reasonable for the firm's counterparties to seek to reduce their financial exposure to it. ${ }^{406}$ In effect, it could trigger a run on the firm's assets and bring Morgan Stanley to the verge of liquidity crisis or collapse.

But there is more. What would make this hypothetical oil spill particularly salient is a shocking revelation that the ultimate owner of the disaster-causing oil tanker was not ExxonMobil or Chevron but Morgan Stanley, a major U.S. banking organization not commonly associated with the oil business. That revelation, in and of itself, could create a far broader political controversy that would inevitably invite additional public scrutiny of the commodity dealings of Goldman, JPMC, and other Wall Street firms. Thus, in effect, an industrial accident could potentially cause a major systemic disturbance in the financial markets. These hidden contagion channels make our current notion of interconnectedness in financial markets seem rather quaint by comparison. FHCs' expansion into the oil, gas, and other physical commodity businesses introduces a whole new level of interconnections and vulnerabilities into the already fragile financial system.

405. By assuming this role of a "super-intermediary," financial institutions effectively-and far more successfully-adopted the business model pioneered by Enron. See William W. Bratton \& Adam J. Levitin, A Transactional Genealogy of Scandal: From Michael Milken to Enron to Goldman Sachs, 86 S. CAL. L. REV. 783, 823-32 (2013).

406. For example, in early 2013 , it was estimated that BP's total losses in connection with the 2010 Deepwater Horizon accident reached at least $\$ 90$ billion. This sum included not only the direct clean-up and remediation costs but also various government fines and accumulating legal expenses. Guy Chazan \& Ed Crooks, Claims May Push BP's Oil Spill Bill to \$90bn, FIN. TIMES, Feb. 5, 2013, http://www.ft.com/intl/cms/s/0/097ca8f4-6f6b-11e2-b906-00144feab49a .html\#axzz2eEZAEPXd. 
The basic economic efficiency-based argument may also be overstating the claim that forcing U.S. FHCs out of the physical commodity and energy business would leave consumers' needs in those markets unmet. Traditional commodity trading companies will almost certainly step in to fill any such gap. These non-bank commodity traders may not be able to offer the same "fully integrated risk management" services to industrial clients by assuming nearly all financial risk (and logistical headaches) inherent in such clients' commodity-driven businesses. That possibility lends some support to the argument for letting banks act as super-intermediaries, or commodity traders plus.

At the same time, however, it begs the real question as to why banks are able to out-compete other commodity traders in this realm, or where that all-important plus comes from. Huge balance sheets, high credit ratings, and access to plentiful and relatively cheap financing - these factors enable large banking organizations to absorb their clients' commodity-related risks at a lower cost than anyone else could. ${ }^{407}$ These unique advantages ultimately stem from the fact that, by taking deposits and serving as the main channel for the flow of payments and credit throughout the economy, banks perform a "special" public service and, therefore, enjoy a special public subsidy through access to federal deposit insurance, special liquidity facilities, and other forms of implicit government guarantees. ${ }^{408}$ In this context, the discussion should focus not on a factual question of whether banks are in the best position to offer these services more efficiently, but on a normative question: should banks be offering them at all?

If banks' superior ability to provide commodity-related services is rooted in the federal subsidy, the answer to that question is not as simple as the efficiency argument assumes. ${ }^{409}$ If taxpayers are the party ultimately conferring this precious eco-

407. See Meyer, supra note 6 (quoting Blythe Masters).

408. See E. Gerald Corrigan, Are Banks Special?, FED. RES. BANK MINNEAPOLIS (1983), http://www.minneapolisfed.org/pubs/ar/ar1982a.cfm.

409. In June 2012, when Moody's downgraded JPMC's credit rating by three levels, the rating agency was quoted as saying that:

[JPMC] benefited from the assumption that there's a "very high

likelihood" the U.S. government would back the bank's bondholders and creditors if it defaulted on its debt ... Without the implied federal backing, [JPMC]'s long-term deposit rating would have been three levels lower and its senior debt would have dropped two more steps.

Dawn Kopecki, JPMorgan Trading Loss Drove Three-Level Standalone Cut, BLOOMBERG (June 21, 2012), http://www.bloomberg.com/news/2012-06-22/ jpmorgan-trading-loss-drove-three-level-standalone-cut.html. 
nomic benefit on banks, taxpayers also have the right to stop banks from abusing that benefit by engaging in risky commercial activities unrelated to their "special" functions. ${ }^{410}$ The choice of moving into the physical commodities business does not belong solely to bank executives-the choice ultimately belongs to the taxpaying, bank-subsidizing public. ${ }^{411}$ If JPMC's management wants to be free to make profits by drilling for and shipping crude oil, it should be able to do so without the estimated $\$ 14$ billion in annual federal subsidy it receives as a "special" banking institution. ${ }^{412}$

\section{Conflicts of Interest, Market Manipulation, and Consumer Protection}

Banks' extensive involvement in physical commodity activities also raises significant concerns with respect to potential conflicts of interest and market integrity. One of the key policy

410. Despite the skillfully constructed legal fiction of "complementarity" of physical commodities trading to derivatives activities, and an even more insidious fiction of derivatives trading as part of the "business of banking," there is no inherent connection or relatedness between traditional banking functions and trading physical barrels of oil.

411. Quantifying this public subsidy, especially in its implicit forms, is an inherently complex task. A recent academic study estimates that, between 1990 and 2010, large financial institutions received an average funding cost advantage of approximately 28 basis points per year, reaching a peak of 120 basis points in 2009. That advantage translates into an average total subsidy of about $\$ 20$ billion per year, topping $\$ 100$ billion in 2009 . Viral V. Acharya et al., The End of Market Discipline? Investor Expectations of Implicit State Guarantees 3 (Jan. 13, 2013) (unpublished manuscript), available at http://papers.ssrn.com/sol3/papers.cfm?abstract_id $=1961656$. To the extent the study focuses on bond credit spreads and uses on-balance sheet financial data, however, it may be underestimating the true size of the implicit public subsidy to large financial institutions.

412. See Editorial, Dear Mr. Dimon, Is Your Bank Getting Corporate Welfare?, BLOOMBERG (June 18, 2012), http://www.bloomberg.com/news/2012 -06-18/dear-mr-dimon-is-your-bank-getting-corporate-welfare-.html (stating that, according to the IMF research and Bloomberg's own analysis of bank balance sheets, JPMC receives a government subsidy worth about $\$ 14$ billion a year).

It is worth noting that section $23 \mathrm{~A}$ of the Federal Reserve Act, which imposes quantitative and qualitative limitations on transactions between federally insured depository institutions and their affiliates, should theoretically prevent the leakage of this public subsidy from banks to their commoditytrading non-bank affiliates. 12 U.S.C. $\$ 371 \mathrm{c}$ (2012). As the recent crisis demonstrated, however, the practical effectiveness of this statutory firewall is subject to considerable doubt. See Saule T. Omarova, From Gramm-LeachBliley to Dodd-Frank: The Unfulfilled Promise of Section 23A of the Federal Reserve Act, 89 N.C. L. REV. 1683, 1769 (2011). 
reasons for separating banking from commerce is the fear of banks unfairly restricting their commercial-market competitors' access to credit, the lifeblood of the economy. Without reliable empirical data, it is difficult to assess the extent to which this obvious form of conflict of interest currently presents a problem in the commodities sector. Yet, there is a heightened danger that banks may use their financial market power to gain an unfair advantage in commodities markets, and vice versa.

Goldman's role in the ongoing aluminum warehousing crisis provides an instructive example. As discussed above, CocaCola complained that Goldman intentionally created a bottleneck at its Metro warehouses in order to drive up market prices for aluminum and sell their own metal stock at the inflated price. It is curious, however, that more industrial end-users did not publicly complain-or complain a lot sooner or louderabout this potential conflict-of-interest situation. Perhaps, this artificial aluminum shortage did not hurt their businesses quite as badly as it did Coca-Cola's. Or maybe they did not think that Goldman was so blatantly self-serving. It is also possible that commercial companies deliberately avoided an open confrontation with Goldman because it was a Wall Street powerhouse with which they had-or hoped to establishimportant credit and financial-advisory relationships. If they were facing Metro as an independent warehousing operator, they might have felt less pressure to keep quiet-and to continue paying high aluminum premia. This form of subtle counterparty coercion may be difficult to detect and police but it raises a legitimate question for further inquiry.

Moreover, metal warehousing operations are only one element in a large financial conglomerate's complex business strategy involving trading in metals and related financial contracts. It is no coincidence that Goldman is "one of the largest traders of derivatives in the metals markets." ${ }^{\text {"113 }}$ Unlike an independent warehouse operator, Goldman can potentially use its storage capabilities not only to generate rental income but also to move commodity prices in a way that would benefit its derivatives positions. According to a Reuters report, "critics question whether banks and trade houses who speculate on price should be allowed to run the warehouses and therefore gain special in-

413. Jack Farchy, Goldman Sachs Heads of Metals to Retire, FIN. TIMES, Oct. 11, 2012, http://www.ft.com/intl/cms/s/0/497280ba-13d0-11e2-8260-00144 feabdc0.html. 
sight into one of the key drivers of price, namely, LME inventories. ${ }^{414}$

This directly implicates serious issues of market integrity. As one of the world's biggest dealers in commodity derivatives, ${ }^{415}$ Goldman can devise and execute highly sophisticated trading strategies across multiple markets. The ability to influence prices of physical assets underlying derivatives, in effect, completes the circle. It makes Goldman's derivatives profits not so much a function of its traders' superior skills or executives' talents, but primarily a function of the firm's structural market power.

It should be noted here that one of the fundamental drivers of the value of any derivative is the degree of volatility of the value of the underlying asset. If the value of the underlying asset is predictably stable, neither hedgers nor speculators would have any reason to enter into derivative contracts tied to that value. Conversely, the higher the volatility, the higher the demand for derivatives instruments allowing transfer of the underlying risk. This basic fact reveals the fundamental incentive for a derivatives dealer with sufficient market power in the underlying physical commodity markets to maintain price volatility in such markets, regardless of the fundamentals of supply and demand, as the necessary condition of continuing viability and profitability of its commodity derivatives business.

Market manipulation in commodities markets has long been "a hot button issue." ${ }^{416}$ In contrast to securities markets, commodities markets are particularly vulnerable to so-called market power-based manipulation that may not involve fraud or deceptive conduct. ${ }^{417} \mathrm{~A}$ large trader can significantly move prices of futures and underlying physical commodities not only by "cornering" the market in a particular product but also by placing very large sell/buy orders in excess of available liquidity. ${ }^{418}$ This salience of market power in commodities market manipulation underscores the potential dangers of allowing large financial institutions to dominate both commodity derivatives

414. Maytaal Angel, Storage Play by Glencore, Trafigura Pushes Up Lead Costs, REUTERS, Sept. 18, 2012, available at http//uk.reuters.com/article/2012/ 09/18/uk-glencore-lead-idUKBRE88H0L420120918.

415. See Farchy, supra note 413.

416. Craig Pirrong, Energy Market Manipulation: Definition, Diagnosis, and Deterrence, 31 ENERGY L.J. 1, 2 (2010).

417. Id. at 3-4.

418. Id. at 4. 
markets and the related cash commodity markets.

Finally, artificially high premia for industrial aluminum translate into higher consumer prices for a wide range of products, from soft drinks to automobiles. Similarly, if JPMC's commodity traders did, in fact, inflate wholesale power prices in California, their manipulative conduct accounts for retail consumers' higher electricity bills. Generally, commodity price inflation is a major component of consumer price inflation. To the extent that banks' direct involvement in physical commodity markets distorts traditional supply-and-demand dynamics and contributes to commodity price volatility, it becomes an important matter of consumer protection.

An unsustainable rise in consumer prices, driven by the rising prices of basic commodities, has significant macroeconomic consequences. The recent spikes in nationwide gasoline and heating oil prices illustrate these systemic effects. Despite the general prevalence of traditional supply-and-demand theories, there is also a legitimate argument that a significant factor explaining these prices is purely financial speculation in oil. ${ }^{419} \mathrm{~A}$ full discussion of this complex issue is beyond the scope of this Article. It is worth noting, however, that large financial intermediaries enable and amplify such speculation by creating, marketing, and dealing in commodity-linked financial products. Indirectly, these intermediaries' physical commodities operations contribute to speculative bubbles in key commodities, which ultimately increase the cost of living for ordinary Americans. Because rises in the costs of basic goods tend to disproportionally affect the poor, this artificially-created price volatility can widen socio-economic disparities that have tangible and potentially grave consequences for social cohesion and civil unity. From this perspective, large FHCs' physical commodities businesses raise potential concerns not only as a matter of consumer protection but also as a matter of macroprudential regulation and even political stability.

\section{Concentration of Economic and Political Power}

Concerns with potential conflicts of interest, market manipulation, and consumer protection are closely connected to

419. See, e.g., Joseph P. Kennedy II, The High Cost of Gambling on Oil, N.Y. TIMES, Apr. 11, 2012, at A23; Robert Lenzner, Speculation in Crude Oil Adds \$23.39 to the Price per Barrel, FORBES, Feb. 27, 2012, http://www .forbes.com/sites/robertlenzner/2012/02/27/speculation-in-crude-oil-adds-23-39 -to-the-price-per-barrel. 
the broader policy concern with excessive concentration of economic power. That concern looms especially large in the context of FHCs' physical commodity trading.

It is difficult to overestimate the importance of this issue for the long-term health and vitality of the U.S. economy and of American democracy. Writing almost a century ago, Justice Brandeis famously warned against the dangers of combination-or "concentration intensive and comprehensive"-that gave financial institutions direct control over industrial enterprises. ${ }^{420}$ Brandeis saw the "subtle and often long-concealed concentration of distinct functions, which are beneficient when separately administered, and dangerous only when combined in the same persons" as a great threat to economic and political liberties. ${ }^{421}$

The global financial crisis of 2008-09 demonstrated the continuing salience of Brandeis's concerns. The taxpayerfunded bailout of large financial conglomerates whose risky activities had contributed to-and, indeed, largely created-the crisis reignited the century-old debate on the role of "financial oligarchy" in American politics. ${ }^{422}$ Not surprisingly, one of the central themes in post-crisis regulatory reform is the prevention of future bailouts of "too-big-to-fail" financial institutions. ${ }^{423}$ The ongoing transformation of large U.S. financial institutions into leading global merchants of physical commodities and energy, however, significantly complicates the reformers' task. By giving banks that are already "too-big-tofail" an additional source of leverage over the economy-and, consequently, the polity-it elevates the dangers inherent in cross-sector concentration of economic power to a qualitatively new level. ${ }^{424}$ When large financial conglomerates that control access to money and credit also control access to such universal production inputs as raw materials and energy, their already outsized influence on the entire economic-and, by extension, political-system may reach alarming proportions. For these reasons, in rethinking the foundational principle of separating banking and commerce, especially in the context of energy and

420. BRANDEIS, supra note 18 , at 4 .

421. Id. at 6.

422. See, e.g., Simon Johnson \& James KWAK, 13 BankERS: The Wall STREeT TAKEOVER AND THE NeXT FinaNCIAL MELTDOWN 12, 28 (2010); Matt Taibbi, Why Isn't Wall Street in Jail?, RoLLING STONE, Mar. 3, 2011, at 44-51.

423. See JoHNSON \& KWAK, supra note 422, at 174-80.

424. Id. at 203-05. 
commodity activities, it is critically important to remember Brandeis's warnings. Reassessing and reasserting the original antitrust spirit of U.S. bank holding company regulation may be the necessary first step in the right direction. ${ }^{425}$

\section{Beyond the Foundational Myth: Limits of Governability and Regulatory Capacity}

An examination of FHCs' physical commodity activities also highlights potential problems such activities pose from the perspective of regulatory design, regulatory process, and firm governability.

Understanding what exactly large U.S. FHCs own and do in global commodity markets is the critical first step toward developing an informed regulatory approach to this issue. Under the current regulatory disclosure system, there is no reliable way to gather and evaluate this information. Existing public disclosure is woefully inadequate to understand and evaluate the nature and scope of U.S. banking organizations' physical commodities trading assets and activities. It may not be feasible or desirable to mandate detailed disclosure of every commercial activity of a large FHC, but when it comes to energy and other key commodities, what is hidden from the public view may be highly consequential. ${ }^{426}$ It is imperative, therefore, to mandate full public disclosure of financial institutions' direct and indirect activities and investments in physical commodities and energy.

Simply mandating more disclosure, however, will not be enough. The recent crisis has demonstrated the limits of disclosure as a regulatory tool, especially in the context of complex

425. See Omarova \& Tahyar, supra note 28 , at 146.

426. The Dodd-Frank Act requires SIFIs to submit to federal regulators enterprise-wide recovery and resolution plans, or "living wills," to help their orderly resolutions in the event of failure. Dodd-Frank Act, Pub. L. No. 111203, §165(d), 124 Stat. 1376, 1426-27 (2010) (codified at 12 U.S.C. $\$ 5365$ (2012)). Goldman, Morgan Stanley, JPMC, and other large FHCs have already submitted their living wills to the Board in July 2012. These documents should provide an exhaustive description of each institution's corporate structure and core business activities. They could give regulators the necessary information on these firms' physical commodity assets and operations. It is not clear, however, whether this is actually the case, as the bulk of the information in these resolution plans is confidential. None of the publicly available portions of the living wills filed to date contain any relevant information on this issue. See Resolution Plans, BD. GOVERNORS FED. RESERVE SYS. (July 2, 2013), http://www.federalreserve.gov/bankinforeg/resolution-plans.htm. 
markets, institutions, and instruments. ${ }^{427}$ Complexity is one of the fundamental drivers of systemic risk, and managing complexity is one of the key challenges in today's financial services sector. ${ }^{428}$ Large U.S. financial conglomerates are already complex, in terms of their corporate structure, risk management, and the breadth and depth of financial services and products they offer. Allowing these firms to run extensive commercial operations that require specialized technical and managerial expertise adds to their internal complexity. Firm-wide coordination and monitoring of operations, finances, risks, and legal and regulatory compliance become all the more difficult in that context. This is particularly true of capital-intensive, operationally complex, and potentially high-risk physical commodity activities. An effective integration of these operations may be further complicated by potential shifts in corporate culture. Thus, the traditionally aggressive risk-taking culture of commodity traders (think Enron) may push the already questionable ethics of bankers beyond the limits of prudency and legality. All of these factors present serious challenges for large financial firms' internal governance and governability.

More importantly, mixing banking with physical commodity trading creates potentially insurmountable challenges from the perspective of regulatory efficiency and capacity. Direct linkages, through the common key dealer-banks, between the vitally important and volatile financial market and the vitally important and volatile commodity and energy market may amplify the inherent fragility of both markets, as well as the entire economy. Who can effectively regulate and supervise this new super-market? And how should it be done?

The U.S. system of financial services regulation is already highly fragmented and ill-suited to detect and reduce systemic risk across different financial markets and products. The expansion of FHCs' activities into yet more new areas subject to extensive regulation under very different regulatory schemesenvironmental regulation, workplace safety regulation, utility regulation-lays the foundation for jurisdictional conflicts on an unprecedented scale. In addition to the several federal bank regulators, the SEC, and CFTC, banking organizations become subject to regulation by the DOE, the FERC, the Environmen-

427. See generally Henry Hu, Too Complex to Depict? Innovation, 'Pure Information,' and the SEC Disclosure Paradigm, 90 TEXAS L. REV. 1601 (2012).

428. See generally Saule Omarova, License to Deal: Mandatory Approval of Complex Financial Products, 90 WASH. U. L. REv. 63 (2012). 
tal Protection Agency (EPA), the Federal Trade Commission, and possibly other federal and state agencies. Yet, none of these many overseers are likely to see the whole picture, leaving potentially dangerous gaps in the regulation and supervision of these systemically important super-intermediaries. An additional complicating factor is the high strategic and geopolitical significance of energy trading. The flow of oil and gas in global markets is as much a matter of foreign policy and national security as it is a matter of business. Accordingly, the State Department could also be expected to insist on a say in the affairs of large U.S. FHCs that import and export oil, gas, and other strategically important commodities. ${ }^{42}$

In terms of substantive regulatory oversight, the situation is equally discouraging. In addition to being the umbrella regulator for BHCs, the Board is now primarily responsible for prudential regulation and supervision of all SIFIs. ${ }^{430}$ As discussed above, physical commodities activities expose financial institutions to qualitatively different, and potentially catastrophic, risks. In addition, commodities operations create potential new channels of contagion and systemic risk transmission. ${ }^{431}$ Yet the Board is not equipped to regulate and supervise companies that own and operate extensive commodity trading assets: oil pipelines, marine vessels, or metal warehouses.

It is not enough to pay lip service to these concerns by simply requiring FHCs to conduct their commercial activities in compliance with the applicable securities, commodities, energy, and other laws and regulations. ${ }^{42}$ Those regulatory schemes are not designed with SIFIs in mind and, therefore, do not address the unique risks-enterprise-wide and systemic-posed

429. One could argue that the State Department might like the idea of big U.S. banks as major players in the global energy markets. These banks may serve as potential sources of vital economic intelligence and levers of increasing American influence in notoriously opaque and strategically important oil and gas markets. It is far from clear, however, how effective the State Department can be in harnessing big private banks' market power to serve the country's strategic objectives, especially if such objectives conflict with the Board's prudential oversight goals. Introducing this element into the mix of policies governing the U.S. financial institutions is likely to make the existing system of financial services regulation even more complicated and less effective.

430. Dodd-Frank Act $\S \S 113,165,124$ Stat. at 1398-1402, 1423-32 (codified at 12 U.S.C. $\$ \S 5323,5364-5365$ ).

431. See supra Part IV.B.1.

432. See supra note 185 and accompanying text. 
by their activities. ${ }^{433}$ Realistically, however, the Board has little choice but rely on FHCs' promises to comply with such parallel regulatory regimes. Without the necessary expertise and a clear legal mandate, neither the Board nor any other financial regulator can be expected to exercise meaningful oversight of large financial institutions' commodity businesses and the risks they generate. This natural limit on regulatory capacity is an important reason for serious reconsideration of $\mathrm{FHCs}^{\prime}$ role in physical commodities markets.

\section{Beyond BANKIng: Pushing Conceptual AND THEORETICAL BOUNDARIES}

This Article has focused upon U.S. FHCs' involvement in physical commodities trading and related commercial activities. In recent decades, however, the intertwined processes of bank disintermediation, functional convergence of financial products, and consolidation of the financial services industry have significantly reduced sector-specific differences among large financial intermediaries. By subjecting all SIFIs to enhanced prudential oversight and orderly resolution requirements typically applied to depository institutions, the Dodd-Frank Act, in effect, acknowledged the fact that systemic risk can be created and transmitted not only by commercial banks and their affiliates but also by investment banks, insurance firms, and other regulated and unregulated financial market participants.

Against this broader institutional backdrop, the analysis presented in this Article raises two additional issues of considerable practical and theoretical significance.

The first question is this: if it is socially desirable to prevent banks from conducting commercial activities in physical commodities, is it also not desirable-and even necessary-to apply the same rule to all large, systemically significant financial institutions? The same public policy concerns that arise with respect to banking organizations' commodity tradingheightened potential for conflicts of interest and market manipulation, an excessive concentration of market power, increased systemic risk from direct linkages between financial

433. Generally, these specialized regulatory regimes pursue policy goals fundamentally different from the goals of prudential regulation and supervision of financial institutions. See generally David B. Spence \& Robert Prentice, The Transformation of American Energy Markets and the Problem of Market Power, 53 B.C. L. REV. 131 (2012) (describing regulation of U.S. oil, gas, and electricity markets). 
markets and economically vital commodities markets, and lessened governability of financial institutions-are equally applicable to similar activities conducted by non-bank SIFIs. Therefore, as a matter of both theoretical consistency and practical efficacy, there is a strong argument for extending the old principle of separation of banking and commerce beyond the banking sector, at least with respect to physical commodities and energy activities.

The second theoretical question stems from the fact that financial institutions' growing involvement in the physical commodities and energy trade pushes the boundaries of the fundamental concept of financial intermediation itself. What are the core functions of financial intermediaries in modern economy? How far are we willing to stretch the definition of $f i$ nancial-as opposed to trade-intermediation as a distinct form of service-based economic activity? The blurring of these boundaries in practice inevitably creates conceptual ambiguity, which in turn may lead to confused and ineffective policy choices and legal doctrines. An empirical analysis of large financial institutions' physical commodity activities provides an opportunity to revisit these foundational concepts as the basis for potentially reconfiguring the entire system of financial services regulation. This, however, is a subject for future inquiry.

\section{CONCLUSION}

This Article has explored the legal, regulatory, policy, and theoretical aspects of an ongoing transformation of large U.S. banking organizations into global merchants of physical commodities and energy. In the absence of detailed and reliable information, it is difficult to draw definitive conclusions as to the social efficiency and desirability of allowing this transformation to continue. What we can already ascertain about U.S. financial institutions' physical commodity assets and activities, however, raises potentially serious public policy concerns that must be addressed through a fully-informed public deliberation. Even if big U.S. FHCs were, in fact, to scale down their physical commodity operations either in response to current regulatory developments or as a temporary market adjustment, it would not obviate the need for such deliberation. Addressing these policy concerns in a timely, open, and publicly minded manner remains a task of the utmost importance, both as an economic matter and as a matter of democratic governance. 